MARCOS VIDO

FATORES IMPEDITIVOS DA NORMATIZAÇÃO BRASILEIRA PARA O USO DO ROBÔ COLABORATIVO NO SETOR INDUSTRIAL

São Bernardo do Campo 
MARCOS VIDO

\title{
FATORES IMPEDITIVOS DA NORMATIZAÇÃO BRASILEIRA PARA O USO DO ROBÔ COLABORATIVO NO SETOR INDUSTRIAL
}

\begin{abstract}
Trabalho de dissertação apresentado ao Centro Universitário FEI, como parte dos requisitos necessários para obtenção do título de Mestre em Engenharia Mecânica. Orientado pelo Prof. Dr. Alexandre Augusto Massote.
\end{abstract}

São Bernardo do Campo 
Vido, Marcos.

FATORES IMPEDITIVOS DA NORMATIZAÇÃO BRASILEIRA

PARA O USO DO ROBÔ COLABORATIVO NO SETOR

INDUSTRIAL / Marcos Vido. São Bernardo do Campo, 2018.

$81 \mathrm{f}$ : : il.

Dissertação - Centro Universitário FEI.

Orientador: Prof. Dr. Alexandre Augusto Massote.

1. Robô colaborativo. . 2. Manufatura avançada. 3. Segurança. 4.

Colaboração humano-robô. I. Massote, Alexandre Augusto, orient. II. Titulo.

Elaborada pelo sistema de geração automática de ficha catalográfica da FEI com os dados fornecidos pelo(a) autor(a). 
Aluno: Marcos Vido

Título do Trabalho: Fatores impeditivos da normalização brasileira para o uso do robô colaborativo no setor industrial.

Área de Concentração: Produção

Orientador: Prof. Dr. Alexandre Augusto Massote

Data da realização da defesa: $26 / 10 / 2018$

\section{ORIGINAL ASSINADA}

\section{Avaliação da Banca Examinadora:}

São Bernardo do Campo,

\section{MEMBROS DA BANCA EXAMINADORA}

Prof. Dr. Alexandre Augusto Massote

Ass.

Prof. Dr. Fábio Lima

Ass. :

Prof. Dr. Elcio Brito da Silva

Ass. :

A Banca Julgadora acima-assinada atribuiu ao aluno o seguinte resultado:

APROVADO $\bigotimes$

\section{VERSÃO FINAL DA DISSERTAÇÃO}

APROVO A VERSÃO FINAL DA DISSERTAÇÃO EM QUE FORAM INCLUÍDAS AS RECOMENDAÇÕES DA BANCA EXAMINADORA
Aprovação do Coordenador do Programa de Pós-graduação

Prof. Dr. Rodrigo Magnabosco 
À minha mãe, à minha esposa Marisa e à minha filha Marília que me apoiaram neste desafio. E ao meu pai (in memoriam) por me apoiar em cumprir com honra a missão prometida. 


\section{AGRADECIMENTOS}

Ao meu orientador, o Prof. Dr. Alexandre Augusto Massote, mais do que um orientador, um incentivador. Pessoa fundamental que, sempre de maneira educada e sempre coerente, me motivou para o desenvolvimento deste trabalho.

Aos os meus professores Cláudia, Dário, Fábio, Gabriela, Mauro e Wilson, pela dedicação, por todos os compartilhamentos de conhecimentos, todas as opiniões e todos os momentos de descontração.

Ao Centro Universitário FEI, por toda a infraestrutura e disponibilidade de recursos essenciais para o desenvolvimento deste trabalho. 
"A mente que se abre a uma nova ideia, jamais voltará ao seu tamanho original"

Albert Einstein 


\section{RESUMO}

Os robôs industriais podem contribuir para melhorar a eficiência, qualidade e produtividade em um ambiente de produção. Eles são rápidos, acessíveis e projetados para executar as operações de trabalho com precisão e repetibilidade. Contudo, em sua aplicação tradicional, os robôs industriais trabalham isolados das pessoas por questão de segurança. Por outro lado, tarefas futuras realizadas por robôs no contexto da Indústria 4.0 exigirão maior proximidade com os humanos, com foco em segurança e colaboração. Os avanços na robótica colaborativa asseguram que o processo de colaboração com segurança ocorra no ambiente de produção. De fato, o principal benefício oferecido pelo robô colaborativo é a possibilidade de trabalhar em condições seguras ao lado de seres humanos em um espaço de trabalho compartilhado. Mas, enquanto a utilização desta nova geração de robôs cresce no mundo, no Brasil este tipo de aplicação, que se iniciou em 2013, enfrenta restrições para o seu uso, principalmente por questões relacionadas à segurança do trabalhador, contidas no conjunto de normas aplicadas ao assunto. O objetivo deste trabalho é identificar os fatores da normatização brasileira que limitam o uso do robô colaborativo nas operações colaborativas no setor industrial brasileiro, e os resultados já mostram que uma adequação da normatização pode contribuir para a utilização desses robôs nestas operações, sem comprometer a segurança do trabalhador e assim acompanhar a tendência já praticada pelos países desenvolvidos, com a possibilidade de ganhos expressivos de produtividade. Esta pesquisa é classificada como exploratória, com abordagem qualitativa.

Palavras-chave: Robô colaborativo. Manufatura avançada. Segurança. Colaboração humanosrobôs. 


\begin{abstract}
Industrial robots can contribute to improve efficiency, quality and productivity in a production environment. They have become faster, more affordable and are designed to be able to work with accuracy and repeatability. However, in their application, the industrial robots are working isolated from humans due to safety reasons. On the other hand, future tasks handled by robots in the context of the Industry 4.0 will require greater proximity to humans, with the focus on safety and collaboration. The advances in collaborative robotics enable the collaboration and security process that should occur in the production environment. In fact, the main benefit offered by the collaborative robot is the possibility to work in conditions of safety alongside humans in a shared workspace. While the application of this new technology is booming in the world, in Brazil this kind of application, which began in 2013, faces restrictions on its use, mainly due to issues related to workers' safety, included in the standards applied to the subject. The objective of this work is to identify the Brazilian standard factors that limit the use of the collaborative robot in the collaborative operations in the Brazilian industrial sector. The results show that an adequate standardization can contribute to the use of these robots in these operations, without compromising workers' safety and thus follow the trend already adopted by developed countries, with the possibility of significant productivity gains. A qualitative research is carried out with an exploratory classification.
\end{abstract}

Keywords: Collaborative robot. Advanced manufacturing. Safety. Human-robot collaboration. 


\section{LISTA DE ILUSTRAÇÕES}

Quadro 1 - Diferenças entre enfoque de pesquisa quantitativa e qualitativa .17

Figura 1 - Exemplos de robôs industriais tradicionais do tipo articulado ................................21

Figura 2 - Volume anual estimado de venda de robô industrial no Brasil e Alemanha..............22

Figura 3 - Princípios de montagem para definição do tipo de processo ....................................24

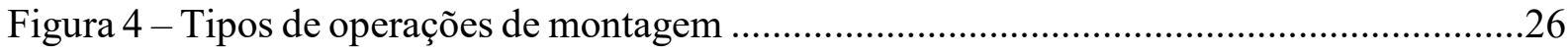

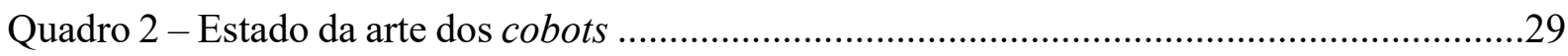

Quadro 3 - Comparação entre os robôs convencionais e os colaborativos ................................32

Figura 5 - Pesquisa bibliográfica em relação à operação colaborativa .....................................34

Quadro 4 - Distribuição de habilidades entre operador e cobot ...............................................36

Quadro 5 - Principais benefícios da cooperação direta entre humano e robô ............................37

Quadro 6 - Comparação de benefícios entre posto de trabalho manual e colaborativo...............37

Quadro 7 - Qualidades entre humanos e cobots em uma operação colaborativa ........................38

Figura 6 - Pesquisa bibliográfica em relação à interação humano-robô ...................................39

Figura 7 - Padrões de segurança para máquinas ..............................................................4

Quadro 8 - Aspectos da interação na robótica e exemplos de novos riscos induzidos................46

Quadro 9 - Tipos de operação colaborativa mencionadas na literatura ...................................49

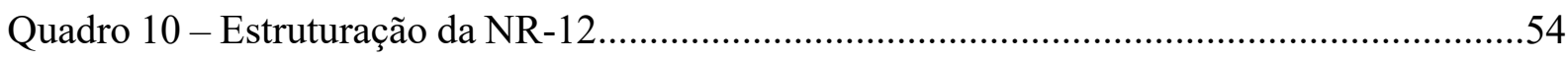

Quadro 11 - Anexos da NR-12 em relação à especificação técnica ISO/ 15066........................54

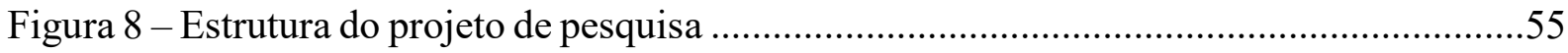

Figura 9 - Diretrizes para o projeto de segurança do sistema robótico ....................................57

Figura 10 - Diagrama conceitual para implantar um posto de trabalho colaborativo..............59

Figura 11 - Layout conceitual de um posto de trabalho colaborativo .......................................60

Figura 12 - Operação de trabalho colaborativa (layout esquemático) .....................................61

Figura 13 - Síntese da normatização para sistemas robóticos................................................62

Figura 14 - Fluxo de análise para identificação dos fatores limitadores .................................64

Quadro 12-Tópicos da NR-12 em relação à especificação técnica ISO/TS 15066 ..................66

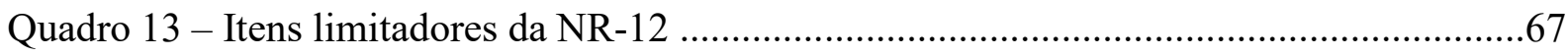

Quadro 14 - Síntese dos resultados da análise comparativa ................................................72

Quadro 15 - Aspectos da colaboração conforme padrões ISO .............................................74 


\section{LISTA DE TABELAS}

Tabela 1 - Pesquisa bibliográfica relacionada a uma operação colaborativa 


\section{LISTA DE ABREVIATURAS}

ABIMAQ Associação Brasileira da Indústria de Máquinas e Equipamentos

ABNT Associação Brasileira de Normas Técnicas

ANSI American National Standards Institute

BG/BGIA Occupational Safety and Health of the German Social Accident Insurance

CNI Conselho Nacional da Indústria

COBOT Collaborative robot

IFR International Federation of Robotics

ISO International Organization for Standardization

HRC Human robot interaction

NR Norma regulamentadora

NR-12 Norma regulamentadora número 12

RIA Robotic Industries Association

PFL Power and force limiting

SSM Speed and Separation Monitoring 


\section{SUMÁRIO}

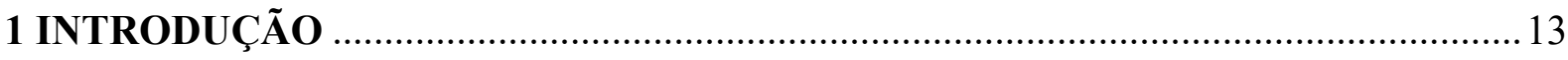

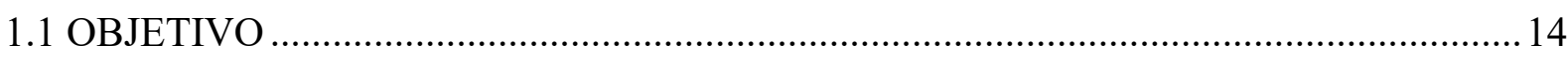

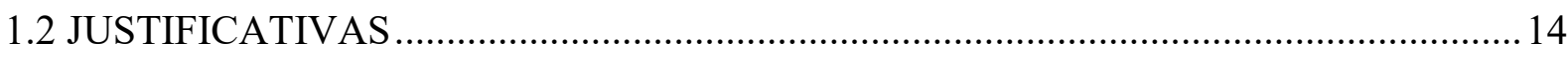

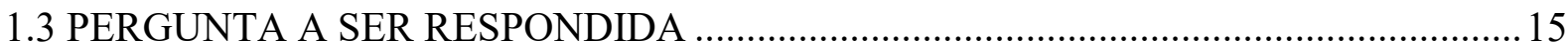

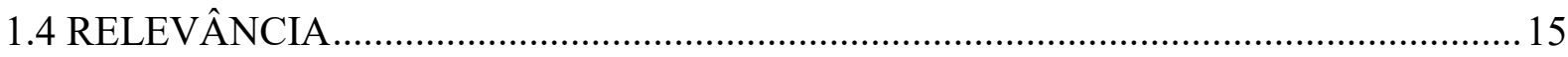

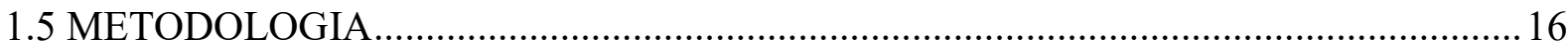

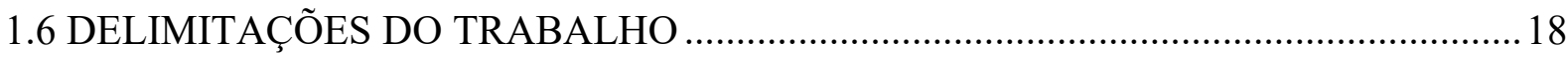

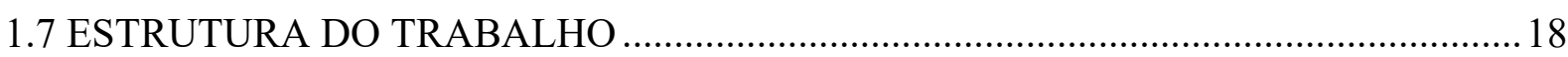

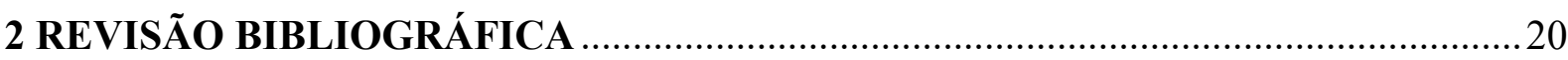

2.1 AUTOMAÇÃO DE PROCESSOS INDUSTRIAIS ………………………………........ 20

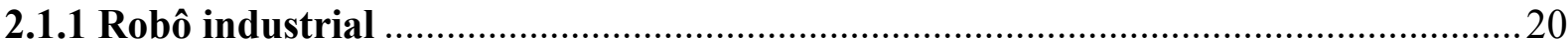

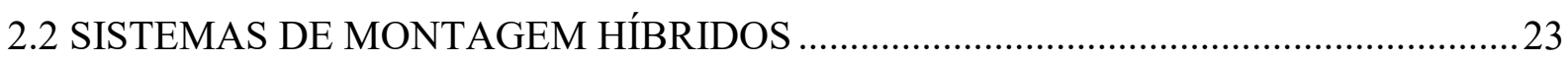

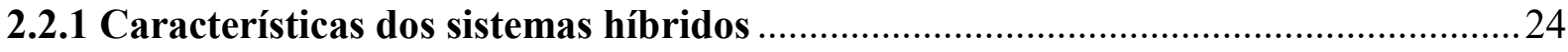

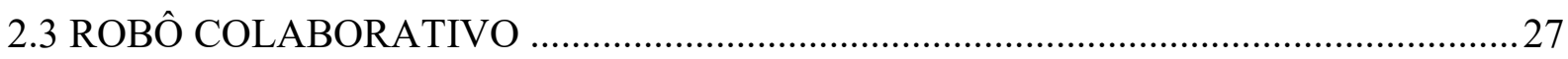

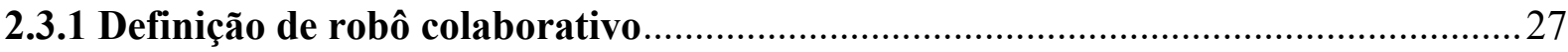

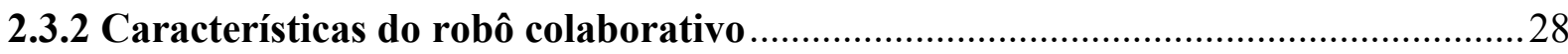

2.3.3 Aspectos tecnológicos do robô colaborativo ………………………………………......30

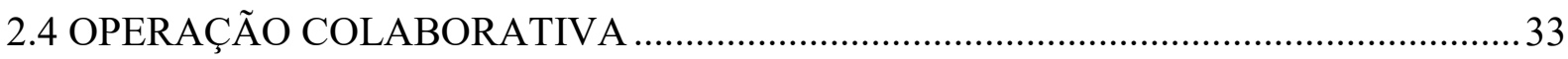

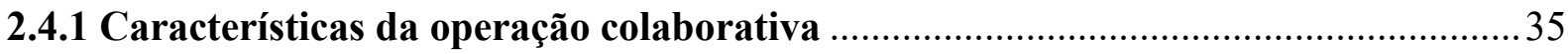

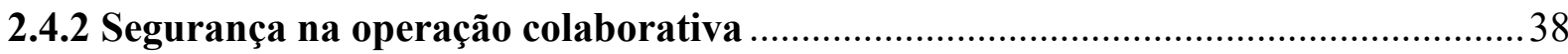

2.5 PADRÕES PARA UTILIZAÇÃO DOS ROBÔS COLABORATIVOS ...............................42

2.5.1 Padrões internacionais ........................................................................................... 43

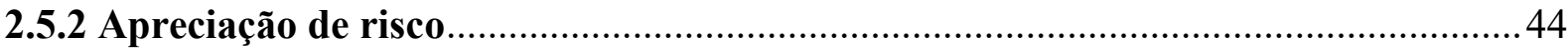

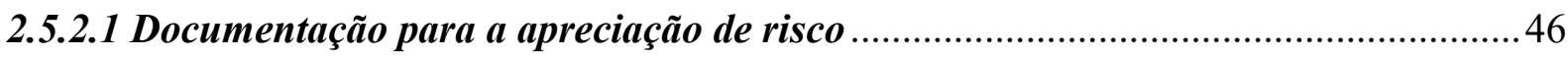

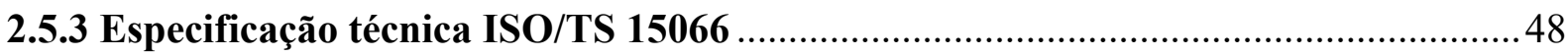

2.5.3.1 Parada monitorada com classificação de segurança .................................................50

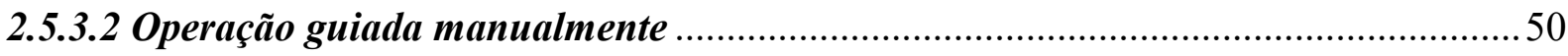

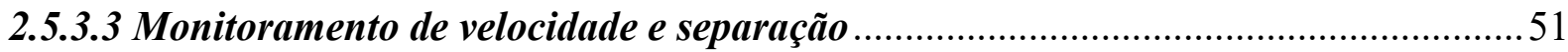




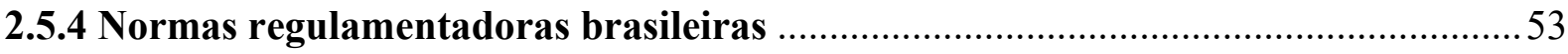

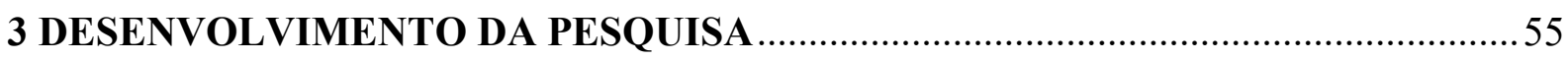

3.1 PROJETO DE SEGURANÇA DE UM SISTEMA ROBÓTICO INDUSTRIAL .............55

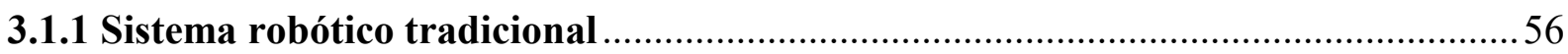

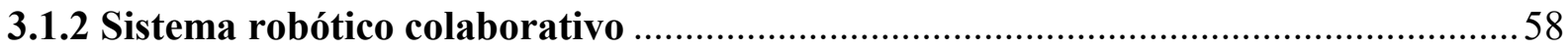

3.2 REQUISITOS PARA CONFIGURAR UMA OPERAÇÃO COLABORATIVA..............59

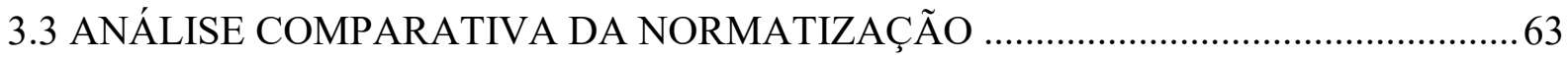

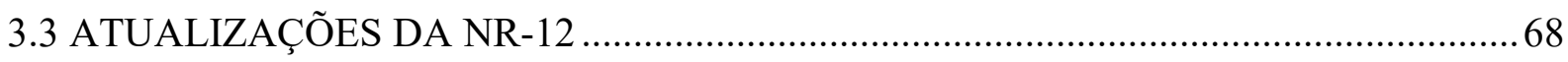

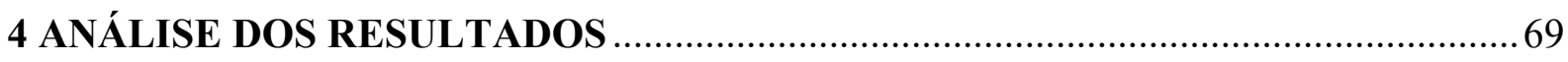

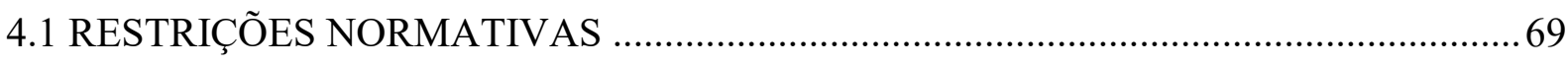

4.2 SEGURANÇA NA OPERAÇÃO COLABORATIVA................................................... 72

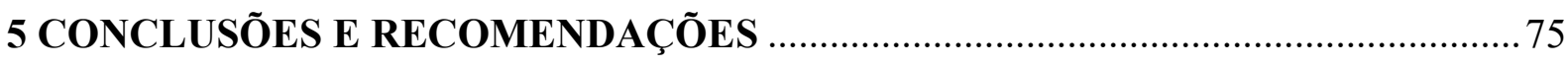

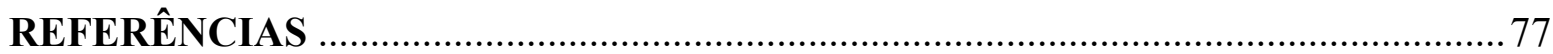




\section{INTRODUÇÃO}

As organizações são moldadas de maneira contínua por desafios técnicos e econômicos. Novos conceitos tecnológicos surgem como suporte para o desenvolvimento das empresas. A Indústria 4.0 representa um avanço no desenvolvimento das indústrias (QIN; LIU; GROSVENOR, 2016). Este tema foi apresentado publicamente pela primeira vez na feira de Hannover na Alemanha, em 2011. Nessa ocasião, foi abordado pelo governo local como um projeto de estratégia de alta tecnologia, que busca informatizar a manufatura por meio da comunicação em tempo real entre humanos, robôs, a logística de fábrica e a administração da empresa (SU et al. 2017; DRATH; HORCH, 2014). Diversas tecnologias digitais denominadas de habilitadoras, tais como robótica avançada, manufatura aditiva, simulação virtual, internet das coisas, nuvem de dados, entre outras, contribuem para inserir as organizações no ambiente da indústria 4.0 (WANG et al., 2016). No escopo deste trabalho, aborda-se a robótica avançada, por meio dos robôs colaborativos.

No contexto da Indústria 4.0 as empresas necessitam de robôs eficientes e capazes de lidar com as condições dinâmicas da produção, e os avanços tecnológicos na área da robótica visam permitir que humanos e robôs interajam com proximidade (ORE et al., 2016). Desta maneira, o robô colaborativo apresenta-se como uma solução para compatibilizar o trabalho entre humanos e robôs (VASIC; BILLARD, 2013; KOOTBALLY, 2016). Isso ocorre devido à capacidade do robô colaborativo de se adaptar aos diversos tipos de indústrias, bem como ao fato de que sua preparação para novas tarefas é rápida (BLOSS, 2016; CERIANI et al., 2015; MICHALOS et al., 2014). Assim, a introdução desta tecnologia na manufatura permite a partilha das diferentes tarefas do processo de produção entre humanos e robôs, além de dispensar os operadores de realizar trabalhos repetitivos e monótonos para então se dedicar às operações de alto valor agregado (IBARGUREN et al., 2015). É o caso dos polos industrializados, como a União Europeia, que almeja obter maior flexibilidade e maior eficiência para melhorar sua posição competitiva no mercado mundial com o uso desta tecnologia (MICHALOS et al., 2014), uma vez que já possui presença no mercado global da robótica. Consequentemente, busca de maneira ativa manter essa posição também no emergente setor da robótica colaborativa (BOGUE, 2016).

Conforme a ABI Research (2015), a Europa representava em 2015 o maior mercado para essa tecnologia com participação de 58\%, os Estados Unidos com 22,8 \% e a Ásia com 19\%. Os demais países totalizam 0,2\%, incluindo o Brasil. De acordo com a ABI Research (2015), o mercado de venda de robôs colaborativos deve exceder US\$ 1 bilhão em 2020 e passar 
de 3.030 unidades instaladas em 2015 para 40.036 unidades em 2020. A participação desse mercado na Ásia aumenta de maneira acentuada, passando de 19\% em 2015 para 57\% até 2020, em particular na China. De acordo com estas projeções, a Ásia irá se posicionar como a região com a maior índice de utilização desta tecnologia, à frente da Europa. Por outro lado, apesar do crescimento em escala desta tecnologia nos países da Europa e Ásia, no Brasil o robô colaborativo ainda não está sendo utilizado em escala devido a problemas de normatização e tecnológicos. Tais robôs são tratados aqui como robôs industriais convencionais, o que impede a agilidade da propagação desta tecnologia, pois, no caso da robótica colaborativa, o uso de robôs para realizar tarefas ao lado ou em conjunto com humanos levanta novos problemas de segurança e saúde no trabalho (MURASHOV; HEARL; HOWARD, 2016).

O Brasil necessita, portanto, adequar as normas que regem seu sistema para viabilizar o processo colaborativo. Como referência, a Comunidade Europeia, onde a Alemanha possui a maior gama de robôs instalados, os Estados Unidos e o Japão já analisam as normas internacionais existentes; a ISO 10218 - parte 1 (2011), para orientar na concepção das características de segurança para os robôs industriais e a ISO 10218 - parte 2 (2011) para as características de segurança de sistemas de robôs para a aplicação dos robôs colaborativos (MARVEL et al., 2016; NAVARRO et al., 2016 e VYSOCKY; NOVAK, 2016). Esta pesquisa busca contribuir para aprofundar o conhecimento sobre o uso do robô colaborativo no Brasil.

\subsection{OBJETIVO}

Identificar os fatores da normatização brasileira que limitam o uso do robô colaborativo em operações colaborativas no setor industrial brasileiro.

Objetivos específicos:

a) verificar como a segurança na operação colaborativa é tratada em outros países;

b) avaliar a normatização brasileira e internacional e fazer um comparativo das restrições relativas a segurança na operação colaborativa.

\subsection{JUSTIFICATIVAS}

A cooperação entre seres humanos e robôs na indústria implica desafios significativos em termos de segurança (PEDROCCHI et al., 2013; KRÜGER; LIEN; VERL, 2009). Entre outros aspectos tecnológicos a serem considerados, tais como a tecnologia de sensores projetada 
para robôs, a segurança representa o problema central do trabalho colaborativo (PEDROCCHI et al., 2013).

O uso do robô colaborativo está evoluindo no mundo e aumentando a defasagem tecnológica entre o Brasil e os países desenvolvidos, embora exista no Brasil potencial para a utilização da robótica colaborativa.

De acordo com o Conselho Nacional da Indústria - CNI (2017), a indústria de transformação participa com $12 \%$ no PIB brasileiro e é responsável por $62 \%$ dos investimentos em pesquisa e desenvolvimento no setor privado, além de colaborar com $15 \%$ do emprego formal e contribuir com $42 \%$ das exportações. Esses dados indicam o potencial de crescimento para a aplicação da robótica colaborativa no cenário da manufatura brasileira, em busca do aumento de produtividade e competitividade, pois robótica é uma das tecnologias habilitadoras para o ambiente da manufatura avançada (TSAROUCHI; SOTIRIS; CHRYSSOLOURIS, 2016; PEDERSEN et. al., 2016).

Ainda no âmbito da indústria, a interação e a colaboração humano-robô são algumas das oportunidades promissoras para o desenvolvimento de aplicações de robôs no futuro (CERIANI et al., 2015), uma vez que a automatização e modernização dos postos de trabalho permitem ganhos de produtividade e eficiência nas empresas. Espera-se também que a robótica seja um dos principais facilitadores da transição para a manufatura avançada (PEDERSEN et. al., 2016).

É importante ressaltar aqui que existe pouca pesquisa acadêmica sobre a interação e a colaboração humano-robô (BDIWI; PFEIFER; STERZING, 2017; TSAROUCHI; SOTIRIS; CHRYSSOLOURIS, 2016).

\subsection{PERGUNTA A SER RESPONDIDA}

A questão central que esta pesquisa tenciona responder é a seguinte:

"Quais são os principais fatores da normatização que limitam o uso dos robôs colaborativos em sua plenitude nas operações industriais no Brasil? ”

\subsection{RELEVÂNCIA}

A interação humano-robô no processo produtivo está em foco na literatura, bem como nas empresas de tecnologia e do setor industrial (TSAROUCHI; SOTIRIS; CHRYSSOLOURIS, 2016). A falta de uma contextualização dos aspectos normativos e tecnológicos na colaboração entre seres humanos e robôs em um posto de trabalho 
compartilhado é uma barreira para as indústrias brasileiras utilizarem esta tecnologia na sua plenitude.

Nesse contexto, este trabalho pretende contribuir para viabilizar o uso dos robôs colaborativos nos diversos tipos de aplicações requeridas pela indústria brasileira. Tal contribuição mostra-se relevante do ponto de vista da indústria, devido aos benefícios em termos de flexibilidade e produtividade que se pode alcançar em uma operação colaborativa (IBARGUREN et al., 2015; CHARALAMBOUS; FLETCHER; WEBB, 2015; MICHALOS et al., 2014; KRÜGER; LIEN; VERL, 2009), mas que ainda são pouco explorados em razão das barreiras legais e tecnológicas para implantar esta tecnologia.

Do ponto de vista social, este trabalho mostra-se também relevante ao tratar dos aspectos da medicina e da segurança do trabalho, pois em um posto de trabalho colaborativo é possível evitar muitas situações de desconforto, ergonomia e insalubridade para a saúde do operador (IBARGUREN et al., 2015; KRÜGER; LIEN; VERL, 2009). Além disso, pode-se também reduzir os encargos trabalhistas que impactam as empresas e o governo, quando se torna necessário afastar um trabalhador por motivo de doença do trabalho.

Este trabalho contribui ainda com a academia para difundir conhecimento e tecnologia junto às indústrias brasileiras, por meio de pesquisa e desenvolvimento sobre as tecnologias habilitadoras da manufatura avançada. Destaca-se aqui, entre tais tecnologias, a aplicação da robótica colaborativa em um ambiente industrial para a colaboração humano-robô, de forma a colaborar com a propagação da manufatura avançada (PEDERSEN et. al., 2016).

\subsection{METODOLOGIA}

Esta é uma pesquisa qualitativa e possui caráter exploratório. A metodologia deste estudo adere às definições de Creswell (2014, p. 52): "utiliza-se a pesquisa qualitativa quando deseja-se compreender os contextos ou ambientes em que os participantes de um estudo abordam um problema ou questão", e de Yin (2015, p. 59), "a pesquisa qualitativa procura capturar condições da vida real, e adota a perspectiva das pessoas que fazem parte destas condições."

A natureza deste estudo se concentra na definição de Sampieri, Collado e Lucio (2013, p. 101) “os estudos exploratórios servem para nos tornar familiarizados com fenômenos relativamente desconhecidos, obter informação sobre a possibilidade de realizar uma pesquisa mais completa relacionada com um contexto particular". Sobre o trabalho acadêmico, Sampieri, Collado e Lucio (2013, p. 30) definem que "a pesquisa é um conjunto de processos sistemáticos 
críticos e empíricos aplicados no estudo de um fenômeno". Sampieri, Collado e Lucio (2013, p. 51) afirmam ainda que "as pesquisas surgem das ideias, não importando o tipo de paradigma que fundamenta nosso estudo nem o enfoque que seguimos”. Flick (2013, p. 126) explica que a pesquisa acadêmica é baseada em "dados coletados por meio de métodos empíricos”. Segundo o autor, em geral se distinguem dois métodos principais: o quantitativo e o qualitativo.

Sampieri, Collado e Lucio (2013, p. 36) argumentam que "se utiliza o estudo quantitativo para consolidar as crenças e estabelecer padrões de comportamento em uma população, enquanto que o estudo qualitativo constrói crenças próprias sobre o fenômeno estudado". O Quadro 1 indica as principais características de ambos os enfoques de pesquisa, com base no estudo de Sampieri, Collado e Lucio (2013).

Quadro 1: Diferenças entre enfoques de pesquisas quantitativa e qualitativa

\begin{tabular}{|c|c|c|}
\hline Definições & Enfoque quantitativo & Enfoque qualitativo \\
\hline Objetividade & Procura ser objetivo & Admite subjetividade \\
\hline $\begin{array}{l}\text { Posição pessoal } \\
\text { do pesquisador }\end{array}$ & $\begin{array}{l}\text { Neutra e imparcial. } \\
\text { Sua posição tenta assegurar procedimentos } \\
\text { rigorosos e objetivos de coleta e análise dos } \\
\text { dados. } \\
\text { Evita que suas propensões e tendências } \\
\text { influenciem nos resultados. }\end{array}$ & $\begin{array}{l}\text { Explícita. } \\
\text { O pesquisador reconhece seus próprios } \\
\text { valores e crenças, que são, inclusive, parte } \\
\text { do estudo. }\end{array}$ \\
\hline $\begin{array}{l}\text { Interação física } \\
\text { entre o } \\
\text { pesquisador e o } \\
\text { fenômeno }\end{array}$ & Distanciada, separada. & Próxima, costuma haver contato. \\
\hline $\begin{array}{l}\text { Formulação do } \\
\text { problema }\end{array}$ & $\begin{array}{l}\text { Delimitado, demarcado, específico. } \\
\text { Pouco flexível. }\end{array}$ & $\begin{array}{l}\text { Aberto, livre, não é delimitado ou } \\
\text { demarcado. } \\
\text { Muito flexível }\end{array}$ \\
\hline Uso da teoria & $\begin{array}{l}\text { Utiliza a teoria para ajustar seus postulados } \\
\text { ao mundo empírico. }\end{array}$ & A teoria é um marco referencial. \\
\hline $\begin{array}{l}\text { Papel da revisão } \\
\text { da literatura }\end{array}$ & $\begin{array}{l}\text { A literatura tem um papel crucial, orienta a } \\
\text { pesquisa. É fundamental para a definição } \\
\text { da teoria, das hipóteses, do desenho e das } \\
\text { demais etapas do processo. }\end{array}$ & $\begin{array}{l}\text { A literatura desempenha um papel menos } \\
\text { importante no início, embora seja realmente } \\
\text { relevante no desenvolvimento do processo. } \\
\text { Algumas vezes, ela indica o caminho, mas o } \\
\text { que realmente indica o rumo é a evolução } \\
\text { dos eventos. O marco teórico é um elemento } \\
\text { que ajuda a justificar a necessidade de } \\
\text { pesquisar um problema formulado. }\end{array}$ \\
\hline Hipóteses & $\begin{array}{l}\text { As hipóteses são testadas. Elas são } \\
\text { estabelecidas para que sejam aceitas ou } \\
\text { rejeitadas, dependendo do grau de certeza } \\
\text { (probabilidade). }\end{array}$ & $\begin{array}{l}\text { As hipóteses são criadas durante o estudo e } \\
\text { em sua conclusão. }\end{array}$ \\
\hline $\begin{array}{l}\text { Desenho da } \\
\text { pesquisa }\end{array}$ & $\begin{array}{l}\text { Estruturado, pré-determinado (precede a } \\
\text { coleta de dados). }\end{array}$ & $\begin{array}{l}\text { Aberto, flexível, construído durante o } \\
\text { trabalho de campo ou a realização do estudo. }\end{array}$ \\
\hline $\begin{array}{l}\text { Natureza dos } \\
\text { dados }\end{array}$ & $\begin{array}{l}\text { A natureza dos dados é quantitativa (dados } \\
\text { numéricos). }\end{array}$ & $\begin{array}{l}\text { A natureza dos dados é qualitativa (textos, } \\
\text { narrativas, significados, etc.). }\end{array}$ \\
\hline
\end{tabular}

Fonte: Autor "adaptado de" Sampieri, Collado e Lucio, 2013, p. 36 
De acordo com Gil (2010, p. 27) a maioria das pesquisas que se realizam com propósito acadêmico, pelo menos em um primeiro momento, assume o caráter de pesquisa exploratória. Yin $(2015$, p. 27) explica que as pesquisas exploratórias têm como propósito "proporcionar maior familiaridade com o problema, com vistas a torná-lo mais explícito ou a construir hipóteses". O autor ressalta também que "na maioria dos casos, a pesquisa exploratória envolve: (I) levantamento bibliográfico e (II) entrevistas” (Gil: 2002, p. 41). Creswell (2007, p. 185) define que "a pesquisa qualitativa é uma pesquisa interpretativa, com o investigador geralmente envolvido em uma experiência sustentada e intensiva com os participantes". Cauchick et al. (2012 p. 52) argumentam que "a pesquisa qualitativa tem como foco os processos do objeto de estudo". Creswell $(2014$, p. 50) caracteriza a pesquisa qualitativa como aquela que "começa com pressupostos e o uso de estruturas interpretativas teóricas que informam o estudo dos problemas da pesquisa, abordando o significado que os indivíduos ou grupos atribuem a um problema social ou humano".

Sampieri, Collado e Lucio (2013, p. 62) explicam que "na pesquisa qualitativa o pesquisador usa os esclarecimentos e as informações provenientes da literatura, enquanto conhecimento sobre o contexto, e se utiliza dele para verificar afirmações e observações a respeito de seu tema de pesquisa naqueles contextos".

Creswell (2014, p. 52) distingue ainda que "se utiliza pesquisa qualitativa quando queremos compreender os contextos ou ambientes em que os participantes de um estudo abordam um problema ou questão".

\subsection{DELIMITAÇÕES DO TRABALHO}

O estudo limita-se à análise da normatização que impede a utilização de robôs colaborativos na indústria brasileira. Embora se reconheça o ganho de produtividade com o seu uso em outros países, neste momento não se avalia o desempenho econômico do posto de trabalho colaborativo. Também não se considera outros aspectos da manufatura avançada, como custos de implantação e retorno de investimento da operação colaborativa.

\subsection{ESTRUTURA DO TRABALHO}

O presente trabalho está dividido em cinco capítulos. Este capítulo apresenta a introdução e as justificativas, expõe o objetivo, a questão que orienta a pesquisa e, também, as suas delimitações. 
O segundo capítulo apresenta a revisão da literatura, contemplando a definição dos robôs industriais e das operações híbridas nos processos de produção. Neste capítulo aborda-se também os tipos de operação colaborativa e os conceitos e requisitos de segurança que permitem a colaboração humano-robô dentro de um ambiente compartilhado.

O capítulo três descreve o desenvolvimento da pesquisa utilizada neste trabalho para fins de comparação entre a normatização nacional e a internacional.

O quarto capítulo apresenta as análises dos resultados obtidos na identificação dos fatores limitadores para o uso do robô colaborativo.

O quinto e último capítulo apresenta as principais conclusões obtidas no estudo, o esclarecimento da questão da pesquisa e dos objetivos propostos. Nele há ainda recomendações para trabalhos futuros que possam agregar mais conhecimento sobre o assunto, em função da abrangência do tema estudado. 


\section{REVISÃO BIBLIOGRÁFICA}

Os conceitos de operação colaborativa na interação humano-robô são fundamentais para atender os objetivos desta pesquisa. Neste capítulo, com base nas referências, são descritas as definições e características dos sistemas híbridos e dos robôs colaborativos. Devido à importância da segurança na operação colaborativa, há um subitem específico sobre esse tema. Há também um tópico sobre normatização para a operação colaborativa, com vistas a ampliar a compreensão da matéria.

\subsection{AUTOMAÇÃO DE PROCESSOS INDUSTRIAIS}

A manufatura, do ponto de vista financeiro, é um referencial da economia mundial. Ter uma estrutura de fabricação é importante para qualquer país, porque impulsiona e estimula todos os outros setores de sua economia (WANG, 2015). Dentro de uma linha de produção, cada processo de montagem de um produto compreende uma grande quantidade de tarefas, e, portanto, faz-se necessário otimizar e automatizar a sequência de operações e os recursos a ela associados para realizar um processo de montagem (KOOTBALLY, 2016).

Diante da concorrência e das demandas de mercado, a manufatura deve ter capacidade de responder de maneira rápida e efetiva às necessidades dos clientes, o que justifica automatizar um processo para competir, inovar, ter flexibilidade e velocidade de entrega do produto (GROOVER, 2017; BROWN; BESSANT, 2003).

\subsubsection{Robô industrial}

Artigo seminal de Gaskill e Went (1996) define o robô industrial como uma máquina de manipular automática, reprogramável, com múltiplos propósitos e com braços com vários graus de liberdade. De acordo com a Robotic Industries Association - RIA (2016), o robô industrial é um operador reprogramável, multifuncional e concebido para manipular materiais, objetos, ferramentas ou dispositivos especiais por meio de movimentos variáveis programáveis para executar diversas atividades. Além dos equipamentos elétricos, pneumáticos, esteiras de transporte entre outros, o robô industrial se apresenta como uma das soluções utilizadas para se automatizar os processos industriais (BROWN; BESSANT, 2003); sua aplicação em um processo automático é essencial para a produtividade dentro do ambiente industrial (GROOVER, 2017; HOLDER et al., 2016; ORE et al., 2016; HARPER; VIRK, 2010; 
BROWN; BESSANT, 2003). A aplicação de robôs na indústria surge na década de 1970, quando começam a ser utilizados na indústria automotiva. Esses robôs se caracterizam pela sua orça elevada, resistência e precisão (MURASHOV; HEARL; HOWARD, 2016). São utilizados nas operações de soldar, pintar, montar, movimentar e testar (DJURIC; URBANIC; RICKLI, 2016; VASIC; BILLARD, 2013). E, a fim de atender às necessidades da indústria em muitos domínios, como o automotivo e o aeroespacial, entre outros, tais robôs se apresentam em diversas configurações, conforme indica a Figura 1 (DJURIC; URBANIC; RICKLI, 2016).

Figura 1: Exemplos de robôs industriais tradicionais do tipo articulado

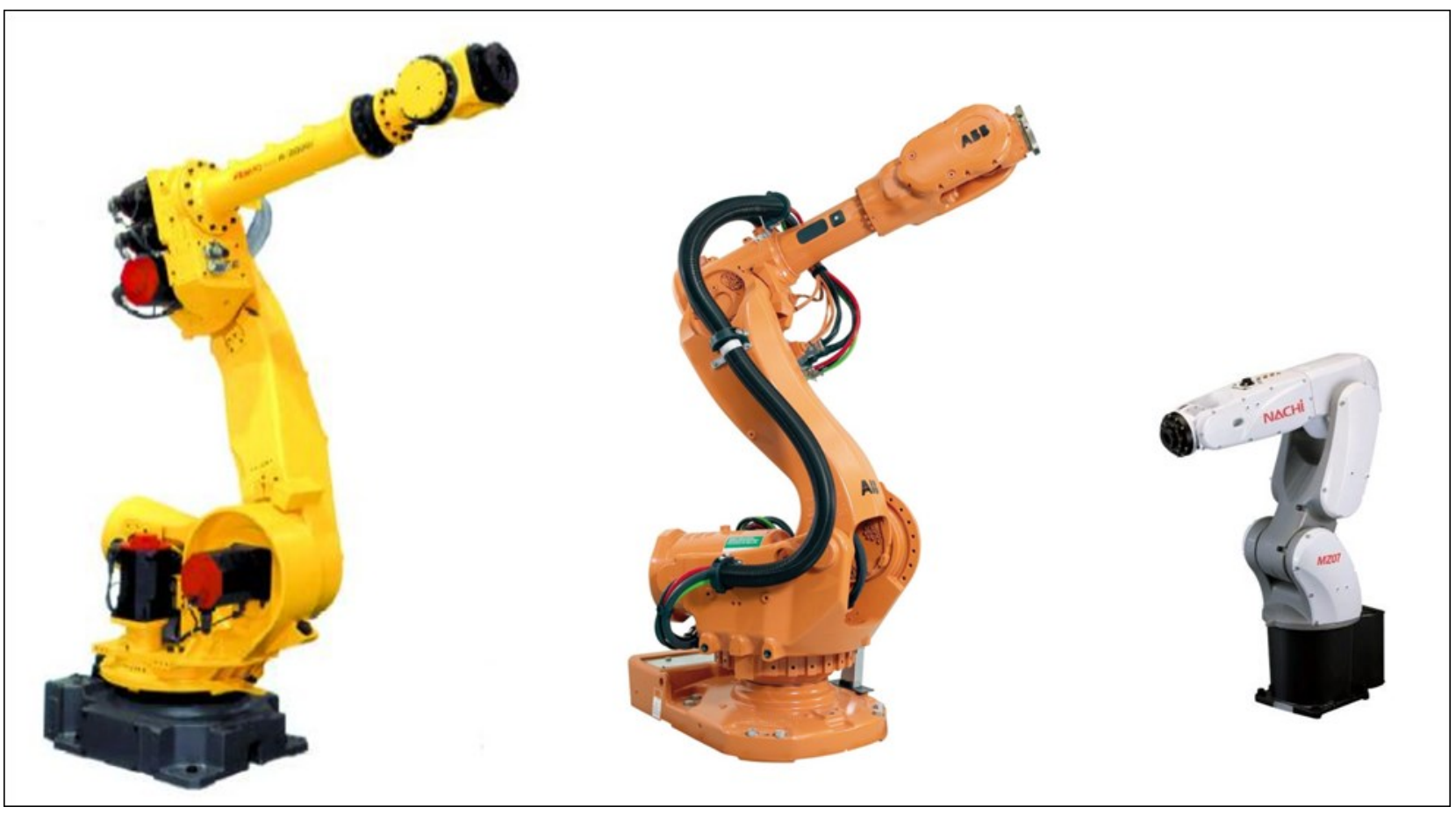

Fonte: Autor "adaptado de" IFR, 2016

Algumas qualidades tecnológicas como precisão em relação ao operador, tornam os robôs industriais importantes, pois eles desempenham tarefas com ciclos de trabalho consistentes e repetitivos, realizam trabalhos perigosos e são recomendados para ambientes insalubres (GROOVER, 2017; DJURIC; URBANIC; RICKLI, 2016; SLACK; BRANDON; JOHNSTON, 2015). Embora proporcione precisão e repetibilidade, o robô industrial se limita pela falta de agilidade, pelo tempo demandado para alternar entre tarefas de maneira rápida e mostra-se também pouco flexível para adaptar-se a outros produtos na célula de produção (KOOTBALLY, 2016). Apesar da interação humano-robô ser uma área de pesquisa avançada, o robô industrial ainda não é autônomo o suficiente para permitir a interação no nível colaborativo (TSAROUCHI; SOTIRIS; CHRYSSOLOURIS, 2016), pois durante a maior parte 
da sua história, os robôs industriais têm sido separados dos humanos por razões de segurança (SHACKLEFORD et al., 2016). De acordo com a International Federation of Robotics - IFR (2017), desde 1999 há aproximadamente 12.900 unidades dos robôs industriais instaladas no Brasil. A Figura 2 apresenta a evolução das vendas de robôs no Brasil desde 2003, quando o mercado robótico se tornou emergente para utilizar esta tecnologia. A Figura 2, compara também a evolução das unidades vendidas aqui com as vendidas na Alemanha, país que apresentou a manufatura avançada em 2011. Conforme a IFR (2016), a indústria automotiva é o principal setor onde se aplicam os robôs industriais no Brasil:

a) Indústria automotiva: $44 \%$ do volume (no mundo 39\%);

b) Operação de manipular: 48,8 \% do volume (no mundo 48\%);

c) Operação de soldar: $32,6 \%$ do volume (no mundo $24 \%$ ).

Em relação aos robôs industriais tradicionais, ainda de acordo com a IFR (2016), a densidade média mundial de robôs industriais em 2015 é de 69 robôs por 10.000 funcionários. Na Alemanha, país considerado o líder no desenvolvimento da manufatura avançada (SU et al., 2017; DRATH; HORCH, 2014), a densidade é de 301 robôs por 10.000 funcionários. O Brasil ocupa a posição de número 21 na classificação global, com o volume de 1.407 robôs instalados em 2015.

Figura 2: Volume anual estimado de venda de robôs industriais no Brasil e na Alemanha

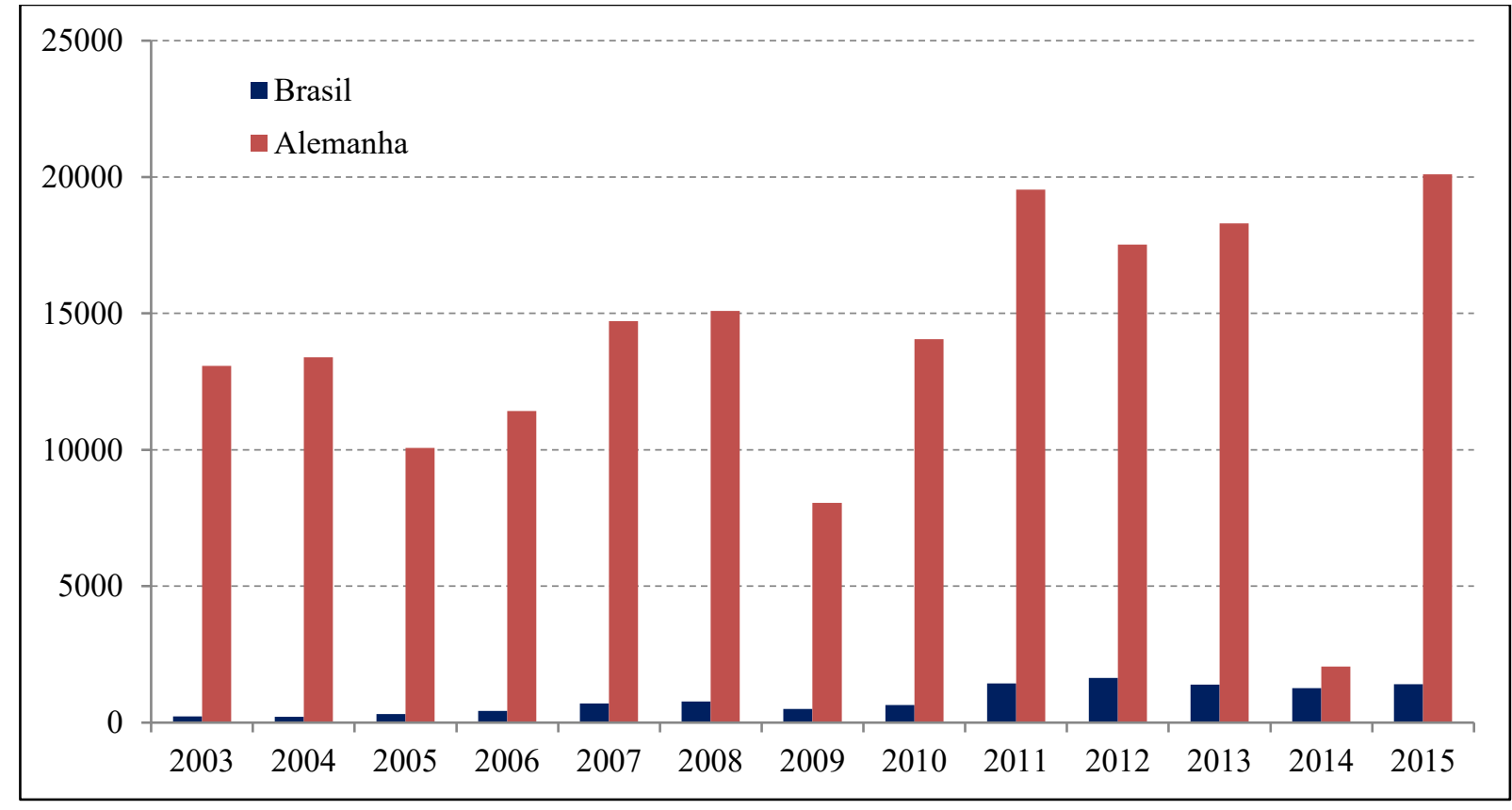

Fonte: Autor "adaptado de” IFR, 2016 


\subsection{SISTEMAS DE MONTAGEM HÍBRIDOS}

Os tipos de processos de linha de montagem descritos na literatura se classificam em: manual, semiautomático ou híbrido e totalmente automáticos (GROOVER, 2017; LOTTER, 2012). O planejamento do tipo de montagem, por sua vez, depende dos fatores que se relacionam ao tamanho do lote, flexibilidade na produção e número de variantes do produto, conforme monstra a Figura 3 (HEILALA; VOHO, 2001).

Dentro da classificação dos tipos de processos, Groover (2017), Lotter (2012) e Takata e Hirano (2011) definem que um sistema automático é ideal para grandes volumes de produção, mas que necessita de um menor número de variantes. Krüger, Lien e Verl (2009) explicam que uma montagem automática possui a vantagem de ser uma operação com poucas quebras, sem fadiga para o operador e de alta produtividade para tarefas de montar de maneira simples. No entanto, normalmente este tipo de processo se restringe à pouca flexibilidade do sistema automático, devido ao alto esforço para programar e ao limite de habilidades para manusear peças complexas (TAKATA; HIRANO, 2011), além de não se poder obter flexibilidade suficiente para uma linha para diferentes produtos (CHEN et al.; 2014). Em relação ao processo de montagem manual, Lotter (2012, p. 167) esclarece que "o trabalho de montagem manual ocupa cerca de $30 \%$ a $50 \%$ do tempo de produção total, o que representa uma enorme contribuição de custos".

Já os sistemas híbridos representam uma vantagem competitiva na indústria há mais de duas décadas (LIEN; RASCH, 2001). Os sistemas de montagem híbridos evoluem como soluções para aumentar a eficiência dos sistemas de produção, a fim de fortalecer sua competitividade (TAKATA; HIRANO, 2011). A colaboração entre humanos e equipamentos e a possibilidade de automatização personalizada por meio de sistemas híbridos são identificadas como novas tecnologias para melhorar a eficiência dos processos de montagem e a produtividade da manufatura (MÜLLER; VETTE; SCHOLER, 2016).

O sistema de montagem híbrido será um dos mais importantes processos de produção no futuro (CHEN et al., 2014), pois as atuais exigências da manufatura incluem um ciclo de produção menor, combinado com vários requisitos do produto que exigem uma alternativa de produção híbrida, capaz de fornecer flexibilidade e eficiência na produção em um único sistema. 
Figura 3: Princípios de montagem para definição do tipo de processo

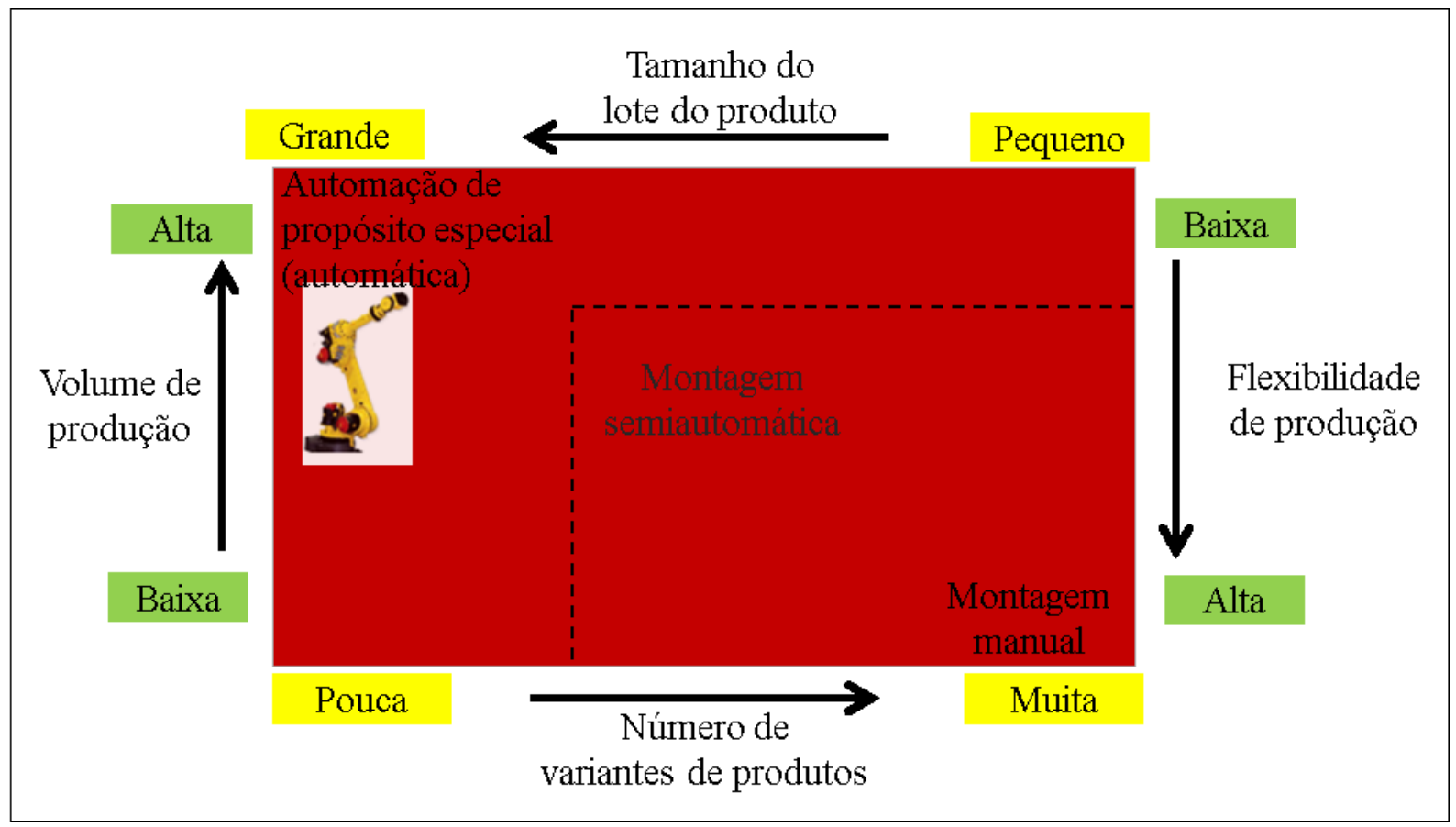

Fonte: Autor "adaptado de" Heilala e Voho, 2001

Lotter (2012, p. 167) argumenta que um sistema de montagem híbrido "permite a facilidade de montar componentes ou diversos produtos em uma estação de trabalho automática combinada com um posto de trabalho manual”. A ideia principal de um sistema híbrido é permitir a colaboração entre humanos e máquinas, compartilhando um espaço de trabalho comum (KRÜGER; LIEN; VERL, 2009). Lien e Rasch (2001) e Heilala e Voho (2001) definem o sistema híbrido como uma estação de trabalho semiautomática, na qual o processo é automatizado de maneira parcial. Heilala e Voho (2001) explicam que uma estação de trabalho híbrida consiste numa combinação de estações de trabalho flexíveis e de diferentes graus de automação. Essa combinação inclui ainda estações de trabalho manual para manipular materiais de maneira automática.

\subsubsection{Características dos sistemas híbridos}

Os sistemas de montagem híbridos são caracterizados por uma cooperação síncrona entre humanos e máquinas, sem retirar a responsabilidade dos humanos. Os sistemas híbridos também se caracterizam por serem competitivos na operação de montagem, quando o processo apresenta volume de produção intermediário, produtos com estruturas básicas similares e com muitas variantes (LIEN; RASCH, 2001). Para esse tipo de sistema, Groover (2017, p.20) define 
que "a combinação homem e máquina obtém vantagens produtivas através de suas forças e atribuições". O sistema híbrido é flexível, permite variações de atividades no posto de trabalho entre a máquina e o operador para atender as demandas, é ágil, rápido de implantar, ergonômico, modular e com interface por meio de componentes padronizados (HEILALA; VOHO, 2001).

Ao se utilizar o posto de trabalho híbrido na manufatura, obtém-se vantagens e desvantagens para o operador. Neste tipo de processo, o operador fornece habilidades sensomotoras incomparáveis para tarefas complexas de manuseio e pode se adaptar de forma rápida às novas sequências de processo, mas é restrito em relação a força e a precisão (KRÜGER; LIEN; VERL, 2009). Já os equipamentos automáticos lidam com as operações nos processos que não precisam de uma grande quantidade de investimentos adicionais para se adaptar às mudanças do produto (TAKATA; HIRANO, 2011).

Os sistemas híbridos têm um benefício econômico na produção de pequenos e médios lotes de produção, mesmo que esse novo paradigma introduza aspectos de segurança obrigatórios e desafiadores (PEDROCCHI et al., 2013). Em termos de custo, pode-se atribuir trabalhos específicos ou volume de trabalho distribuído entre humanos e equipamentos em um posto de trabalho híbrido, a fim de proporcionar um equilíbrio entre o custo do trabalho manual e o investimento de capital no equipamento (THIEMERMANN, 2004). Nos sistemas de montagem híbridos, as operações de processos que exigem mudanças significativas relacionadas ao produto são alocadas aos humanos, enquanto os equipamentos lidam com as operações nos processos que não precisam de uma grande quantidade de investimentos adicionais para se adaptar às mudanças do produto (TAKATA; HIRANO, 2011).

No âmbito da robótica colaborativa, um exemplo seguro e flexível para a colaboração entre humanos e robôs é a célula híbrida, uma maneira promissora de alcançar melhor produtividade, ou seja, o oposto das células manuais (TSAROUCHI; SOTIRIS; CHRYSSOLOURIS, 2016). A importância do trabalho colaborativo no posto de trabalho híbrido traz benefícios de produtividade e qualidade. Limitações do robô e do operador se compensam em uma operação colaborativa (TSAROUCHI; SOTIRIS; CHRYSSOLOURIS, 2016; TAKATA; HIRANO, 2011; KRÜGER; LIEN; VERL, 2009; LIEN; RASCH, 2001). A fim de atingir maior potencial na colaboração, uma ótima divisão do trabalho que se processa deve ser direcionada para o operador e o robô respectivamente (MÜLLER; VETTE; SCHOLER, 2016). Além disso, um layout de estação de processo de natureza flexível deve fornecer alta flexibilidade de conversão e transformação. Devido ao espaço de trabalho compartilhado, o layout da fábrica pode ser usado de forma muito eficiente e melhorar a utilização da capacidade. A remoção dos sistemas de segurança permite ao operador a 
oportunidade de entrar no espaço de trabalho do robô a qualquer momento, sem perigo (MÜLLER; VETTE; SCHOLER, 2016).

Na montagem híbrida ou na colaboração humano-robô, o robô é um colega de trabalho ativo. O mesmo realiza tarefas de montar peças já posicionadas e coordenadas pelo operador. Durante a operação de montar, o robô pode monitorar as atividades do operador e coordenar de maneira adequada em conjunto com o operador o plano de montar da estação (CHEN et. al., 2014). No entanto, pode induzir estresse extra para operadores, quando não se projetam as linhas de montagem de maneira adequada (KRÜGER; LIEN; VERL., 2009). Um sistema de montagem híbrido exibe tanto a eficiência dos robôs quanto a flexibilidade dos seres humanos. A Figura 4 ilustra três abordagens de processos para montar descritas por Lotter (2012), que se configuram com base no volume de produção previsto e também na flexibilidade do sistema que se necessita. No sistema híbrido colaborativo, de acordo com Takata e Hirano (2011), humanos e robôs cooperam para realizar tarefas de montar. Esse sistema tem a vantagem de maximizar a eficiência do robô e a flexibilidade humana.

Figura 4: Tipos de operações de montagem

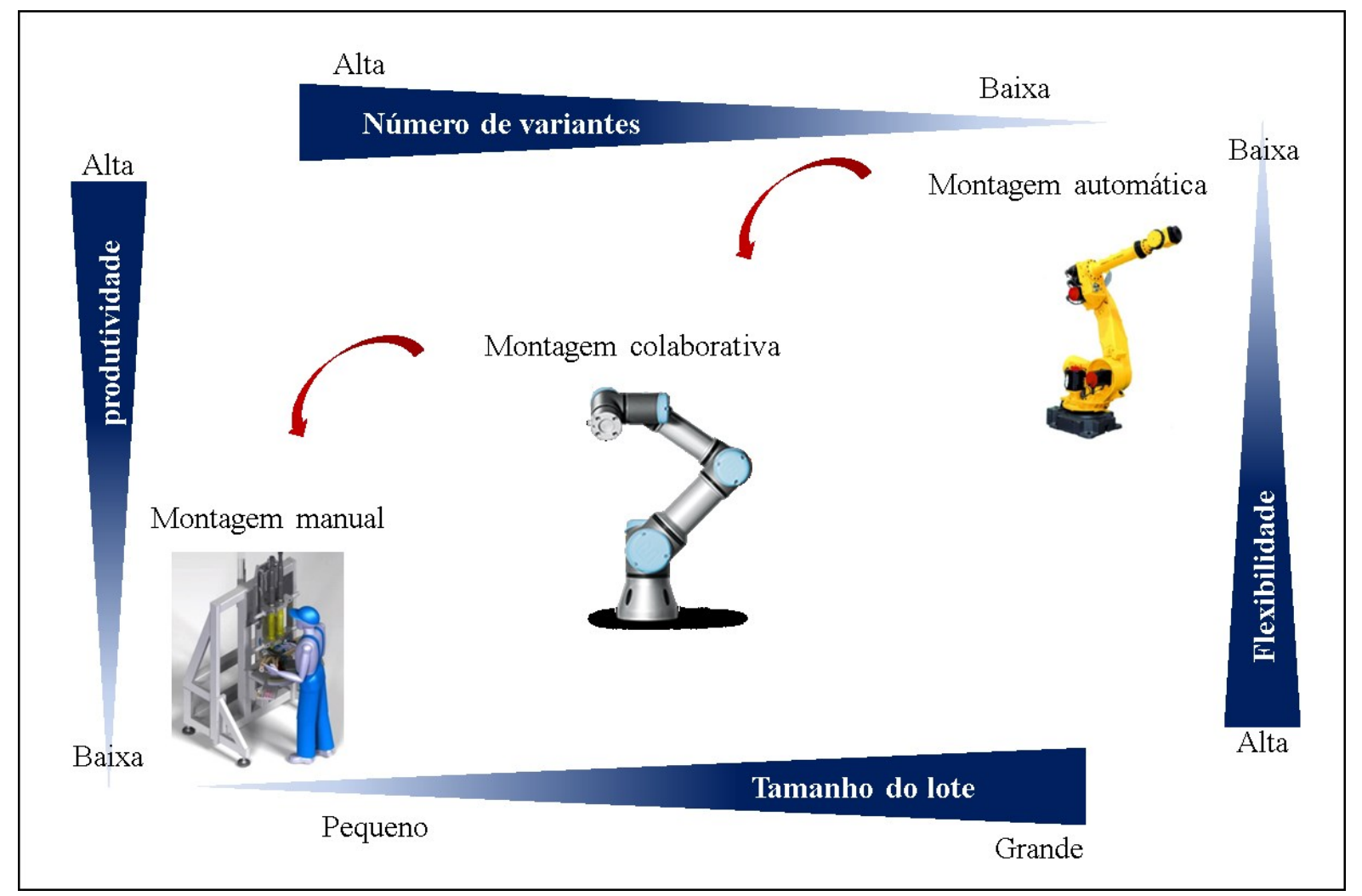

Fonte: Autor "adaptado de" Lotter, 2012; Heilala e Voho, 2001 


\subsection{ROBÔ COLABORATIVO}

O desenvolvimento do mercado da robótica colaborativa é impulsionado principalmente por aplicações na produção e montagem de produtos eletrônicos, em novos processos na indústria automotiva e nos diversos tipos de operação de manipulação em empresas de manufatura de pequeno e médio porte (BLOSS, 2016).

A introdução da robótica colaborativa na manufatura avançada nos últimos anos faz parte das prioridades competitivas da produção (LIEN; RASCH, 2001). No âmbito tradicional da robótica, a tendência da automação se volta para aplicações industriais com requisitos da robótica colaborativa, ou colaboração humano-robô, que representa uma mudança qualitativa nas clássicas aplicações de robôs em processos de manufatura (HARPER; VIRK, 2010).

\subsubsection{Definição de robô colaborativo}

A introdução da robótica colaborativa na manufatura avançada nos últimos anos faz parte das prioridades competitivas da produção (LIEN; RASCH, 2001). No âmbito tradicional da robótica, a tendência da automação se volta para aplicações industriais com requisitos da robótica colaborativa, que representa uma mudança qualitativa nas clássicas aplicações de robôs em processos de manufatura (HARPER; VIRK, 2010).

A ideia do projeto do robô colaborativo é poder coexistir e cooperar com os humanos no ambiente produtivo. Os robôs colaborativos são concebidos para que a operação permita que os robôs cumpram suas funções na manufatura, como unidades produtivas independentes. Isso deve ocorrer com segurança e, também, assegurando a convivência dos robôs com os operadores (IBARGUREN et al., 2015, KRÜGER; LIEN; VERL, 2009).

O robô colaborativo foi desenvolvido inicialmente em 1999 pelos professores Edward Colgate e Michael Peshkin na Northwestern University em Evanston, Estado de Illinois nos Estados Unidos da América (PESHKIN et al., 2001). Segundo os autores, o mesmo é definido como um robô projetado para interagir fisicamente com humanos em um espaço de trabalho compartilhado e também para suprir a lacuna entre uma estação de trabalho manual e uma automática. Neste sistema, humanos e robôs cooperam para realizar tarefas de montagem e têm a vantagem de maximizar a eficiência do robô e a flexibilidade humana (TAKATA; HIRANO, 2011). O termo robô colaborativo em inglês é cobot ou collaborative robot. Este estudo menciona o robô colaborativo como cobot. 


\subsubsection{Características do robô colaborativo}

Bertolini et al. (2016) definem que é possível distinguir duas tipologias principais de robôs industriais: robôs que operam de maneira isolada dos operadores, que em geral são limitados por aparatos de segurança, e os cobots, que são desenvolvidos para interagir de maneira física com os operadores. De maneira geral, o cobot é criado para ser uma ferramenta de trabalho complementar aos operadores, sendo que esta perspectiva de interação orienta os critérios para projetar e implantar os mesmos (DJURIC; URBANIC; RICKLI, 2016). A RIA (2017) afirma que o cobot é programado para executar suas ações e corrigir suas funções de acordo com as mudanças em seu ambiente. Seu principal objetivo consiste na economia de energia humana e na melhora contínua na precisão de aplicações específicas.

Djuric, Urbanic e Rickli (2016) definem que se implantam as soluções com cobots para associar a capacidade de força e resistência dos robôs com a flexibilidade e a tomada de decisão dos operadores. Utilizam-se os mesmos em linhas de produção para aplicações de manipular produtos ou realizar montagem de maneira colaborativa (BICCHI; PESHKIN; COLGATE, 2008). Peshkin e Colgate (1999) explicam que os cobots se destinam a uma interação direta com um trabalhador humano, ao manipular uma carga útil que se compartilha. Utiliza-se o cobot também para proporcionar ao operador a redução de suas preocupações ergonômicas, que surgem devido ao trabalho de manusear carga física, ao mesmo tempo em que se melhora a segurança, qualidade e produtividade (CHERUBINI et al.; 2016). Krüger, Lien e Verl (2009) ressaltam que o objetivo é habilitar o trabalho colaborativo entre humanos e robôs, uma vez que os cobots melhoram a flexibilidade dos processos industriais, ao mesmo tempo em que diminuem a fadiga dos operadores (CHERUBINI et al., 2016; DJURIC; URBANIC; RICKLI, 2016; BLOSS, 2016; PEDROCCHI et al., 2013).

Os fabricantes de robôs desenvolvem diversos modelos de cobots para o manuseio de produtos de pequeno e médio porte, de acordo com suas características e tipos de aplicações possíveis, conforme ilustra o Quadro 2, e visam a sua utilização nas indústrias que procuram tecnologias de manufatura ágil. De maneira geral, aplicam-se os cobots para manipular capacidade de carga útil baixa, que varia de 0,5 à $14 \mathrm{~kg}$ (KHALID et al., 2016). 
Quadro 2: Estado da arte dos cobots

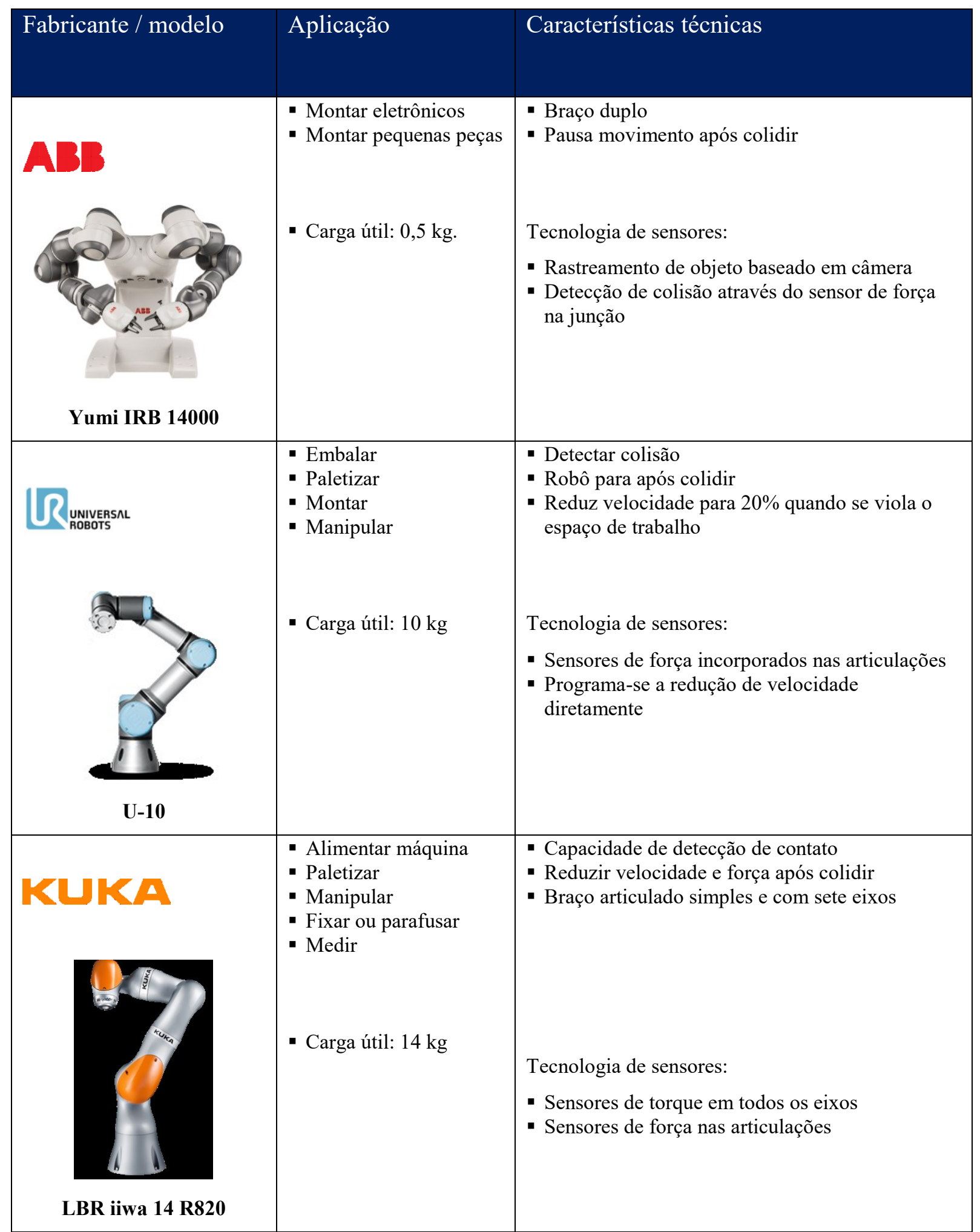

Fonte: Autor "adaptado de" Khalid et al., 2016

Os cobots são projetados para manipular produtos de baixo peso, contudo, para que os cobots alcancem todo o seu potencial, os produtos de médio e alto peso devem poder operar 
também ao lado dos humanos, já que 45\% do mercado global envolve manipulação de produtos com peso acima de $15 \mathrm{~kg}$ (BOGUE, 2016). A interação humano-robô em um ambiente industrial se impulsiona pela ergonomia, flexibilidade, qualidade e custo de produção (TSAROUCHI; SOTIRIS; CHRYSSOLOURIS, 2016; SCHOLER; VETTE; RAINER, 2015; KRÜGER; LIEN; VERL, 2009; THIEMERMANN, 2004). Os benefícios ergonômicos e de produtividade do posto de trabalho resultam, portanto, de se combinar a força e interface do computador do cobot com a destreza do operador (DJURIC; URBANIC; RICKLI, 2016; PESHKIN; COLGATE, 1999).

Os potenciais benefícios dos cobots são enormes e abrangentes, pois eles se colocam em equipe junto aos operadores em linhas de produção flexíveis (KRÜGER; LIEN; VERL, 2009). Um fator crucial para o aprimoramento da flexibilidade do cobot e para uma interação viável é a disponibilidade de cobots tecnologicamente seguros (CERIANI et al., 2015).

\subsubsection{Aspectos tecnológicos do robô colaborativo}

Conforme descrito no item 2.3.2, os cobots devem operar ao lado dos humanos em um espaço de trabalho compartilhado sem a necessidade de proteção convencional, como grades de segurança, barreiras de luz sensorizadas, entre outras (BOGUE, 2016; PESHKIN; COLGATE, 1999). Bogue (2016) esclarece que os cobots oferecem uma série de vantagens significativas em relação às suas contrapartes convencionais, tais como menores custos de instalação, devido à falta de aparatos de segurança, que também produz economia de espaço, à programação mais simples, que reduz o tempo e os custos de comissionamento e também permite uma rápida adaptação às novas tarefas.

Com base nas configurações mecânicas dos robôs descritos pela IFR (2016), Peshkin et al. (2001) explicam que as propriedades cinemáticas dos cobots diferem de maneira considerável das de outros robôs. Segundo os autores, os cobots têm apenas um grau mecânico de liberdade, de maneira independente da sua dimensão na área de trabalho. A direção instantânea de movimento associada a esse único grau de liberdade é ativamente servocontrolada, ou orientada, dentro do espaço na área de trabalho.

Os cobots são flexíveis para executar outras atividades no chão de fábrica (DJURIC; URBANIC; RICKLI, 2016), podem trabalhar e colidir de maneira gentil com os humanos, pois os braços articulados deste tipo de robô são equipados com sensores de força interna. Por isso, a detecção de colisão, a suspensão imediata e a redução da velocidade após a violação do espaço de trabalho são características comuns dessa tecnologia (KHALID et al., 2016). 
Vysocky e Novak (2016) e Charalambous, Fletcher e Webb (2015) explicam que com os avanços tecnológicos recentes os cobots se tornaram mais leves, compactos e são projetados tendo a segurança humana como prioridade, a fim de potencializar a colaboração.

O cobot utiliza interfaces gráficas menos dispendiosas, e possui maior segurança (DJURIC; URBANIC; RICKLI, 2016). Djuric, Urbanic e Rickli (2016) mencionam que vários tipos de cobots contêm configurações que aumentam a complexidade de programação em modo off-line e on-line, mas a facilidade do uso é uma característica fundamental destes robôs. Segundo os autores, algoritmos de controle especiais, interface homem-máquina e sensores integrados para abordar soluções de colisão e segurança se integram nos projetos atuais desses robôs, a fim de proporcionar reprogramação rápida e flexibilidade de gerenciamento de tarefas.

Djuric, Urbanic e Rickli (2016) e Peshkin e Colgate (1999) indicam que os cobots interagem com humanos e produzem superfícies virtuais desenvolvidas por um software que restringe e orienta o movimento da carga útil que se compartilha. Esse movimento é realizado com o emprego de potência reduzida.

Em relação aos padrões de segurança para a interação em um posto de trabalho compartilhado, Djuric, Urbanic e Rickli (2016) explicam que durante o desenvolvimento do projeto do cobot, os fabricantes definem seis níveis de medição de redução de riscos:

a) Baixa carga útil e baixa inércia do robô;

b) Evitar ferimentos ao conceber o robô com estrutura leve;

c) Limitar potência e velocidade;

d) Detectar colisão que se baseia em software, bloqueio manual de endereço de retorno e outros perigos específicos da aplicação;

e) Usar equipamento de proteção pessoal;

f) Ajustes que se baseiam em percepção real no ambiente de trabalho.

Os níveis de a, b, c, d são medidas que atendem os padrões para o projeto mecânico do robô colaborativo. Enquanto que os níveis e, f são medidas para reduzir os riscos específicos, que se aplicam ao espaço de trabalho colaborativo (DJURIC; URBANIC; RICKLI, 2016). No entanto, mesmo com a tecnologia embarcada no cobot para permitir o trabalho colaborativo, o humano ainda é o componente fundamental nas operações colaborativas (GROOVER, 2017). O Quadro 3 apresenta as características dos tipos de robôs utilizados na indústria. 
Quadro 3: Comparação entre os robôs convencionais e os colaborativos

\begin{tabular}{|c|c|c|}
\hline Aspectos & $\begin{array}{l}\text { Robô industrial tradicional } \\
\text { (célula robotizada) }\end{array}$ & $\begin{array}{l}\text { Robô colaborativo } \\
\text { (posto de trabalho colaborativo) }\end{array}$ \\
\hline \multicolumn{3}{|l|}{$\begin{array}{l}\text { Arranjo físico do } \\
\text { posto de trabalho }\end{array}$} \\
\hline Capacidade carga & Acima de $15 \mathrm{~kg}$ & Até $14 \mathrm{~kg}$ \\
\hline Aplicações & $\begin{array}{l}\text { Manipular, paletizar, soldar grandes } \\
\text { produtos, atividades insalubres, não } \\
\text { ergonômicas }\end{array}$ & Manipular, montar, testar, paletizar \\
\hline Tipo de tarefas & $\begin{array}{l}\text { Periódicas e repetitivas; mudanças } \\
\text { infrequentes }\end{array}$ & $\begin{array}{l}\text { Mudanças frequentes na tarefa; tarefas não } \\
\text { repetidas } \\
\text { Instruções on-line e suportadas por métodos } \\
\text { no modo off-line do cobot }\end{array}$ \\
\hline Tipo de produto & Pesados, de difícil manuseio & Leves, pequenos \\
\hline Tipo de empresas & $\begin{array}{l}\text { Automotiva, fornecedores de } \\
\text { autopeças, embalagens }\end{array}$ & $\begin{array}{l}\text { Automotiva, indústria farmacêutica, } \\
\text { cosméticos, eletrônicos }\end{array}$ \\
\hline $\begin{array}{l}\text { Customização de } \\
\text { produto }\end{array}$ & $\begin{array}{l}\text { Baixo devido ao difícil acesso a outros } \\
\text { tipos de aplicações }\end{array}$ & $\begin{array}{l}\text { Baixo devido ao difícil acesso a outros tipos } \\
\text { de aplicações }\end{array}$ \\
\hline $\begin{array}{l}\text { Aparatos de } \\
\text { segurança }\end{array}$ & $\begin{array}{l}\text { Grades de proteção, PLC, PLC de } \\
\text { segurança, cortina de luz, barreira de } \\
\text { luz, sistema de alarme de segurança }\end{array}$ & $\begin{array}{l}\text { Não necessita de aparatos de segurança } \\
\text { Sensores de segurança embarcados no robô }\end{array}$ \\
\hline Nível de interação & $\begin{array}{l}\text { Não é possível interagir com pessoas } \\
\text { com segurança }\end{array}$ & Interagir com pessoas com segurança \\
\hline Normatização & $\begin{array}{l}\text { ISO 10218: partes } 1 \text { e } 2 \\
\text { ISO } 12000 \\
\text { NR-12 }\end{array}$ & $\begin{array}{l}\text { ISO 10218: partes } 1 \text { e } 2 \\
\text { EN ISO } 12000 \\
\text { ISO/TS } 15066\end{array}$ \\
\hline $\begin{array}{l}\text { Nível de cognição } \\
\text { com o operador }\end{array}$ & $\begin{array}{l}\text { Quase nulo: raramente irá interagir } \\
\text { com o trabalhador, somente quando } \\
\text { programado }\end{array}$ & $\begin{array}{l}\text { Alto: devido à colaboração direta no posto } \\
\text { de trabalho } \\
\text { Interação frequente com o operador }\end{array}$ \\
\hline $\begin{array}{l}\text { Custo com } \\
\text { integração da célula }\end{array}$ & $\begin{array}{l}\text { Alto, devido a: custo com } \\
\text { componentes de segurança, disposição } \\
\text { e layout, instalações industriais } \\
\text { (energia, ar comprimido) }\end{array}$ & Baixo devido à tecnologia dos cobots \\
\hline Tipo de instalação & Fixa & Flexível e portátil \\
\hline Nível de instalação & $\begin{array}{l}\text { Complexa, envolve programação de } \\
\text { robô, PLC e montagem mecânica } \\
\text { elétrica }\end{array}$ & $\begin{array}{l}\text { Fácil manuseio, programação realizada pelo } \\
\text { operador, de acordo com a aplicação }\end{array}$ \\
\hline $\begin{array}{l}\text { Características da } \\
\text { produção }\end{array}$ & $\begin{array}{l}\text { Alto volume, baixa flexibilidade, } \\
\text { difícil para intercambiar com outro } \\
\text { produto }\end{array}$ & $\begin{array}{l}\text { Baixo volume, alta flexibilidade, fácil de } \\
\text { adaptar para outro produto }\end{array}$ \\
\hline Custo & $\begin{array}{l}\text { Rentável somente com tamanho de lote } \\
\text { médio a grande }\end{array}$ & Rentável mesmo no pequeno nível de lote \\
\hline
\end{tabular}

Fonte: Autor "adaptado de" Djuric, Urbanic e Rickli, 2016 


\subsection{OPERAÇÃO COLABORATIVA}

A colaboração direta entre humano e robô se define como um espaço de trabalho que se compartilha e se sobrepõe para os humanos e os robôs (THIEMERMANN, 2004). O conceito de colaboração é uma relação entre duas ou mais partes que trabalham de maneira conjunta em

direção a objetivos comuns. É semelhante ao trabalho em equipe. O tipo mais próximo de colaboração na robótica colaborativa envolve operador e robô que processam a mesma peça de trabalho (STULGIENE; CIUTIENE, 2014). Neste tipo de colaboração, o operador trabalha próximo da área de trabalho do robô, sem separação física, para que ambas as partes possam trabalhar simultaneamente. Como o foco do estudo é na área da engenharia de produção, utilizase a definição da International Organization for Standardization (ISO, 2011), que estabelece a colaboração como um tipo especial de operação conjunta entre um humano e um robô que compartilham um espaço de trabalho comum (STULGIENE; CIUTIENE, 2014).

Bdiwi, Pfeifer e Sterzing (2017) comentam que inúmeros cientistas e pesquisadores têm grandes expectativas de estabelecer uma aplicação industrial na qual humanos e robôs possam cooperar sem barreiras de proteção, de maneira segura e eficiente. No decorrer desse processo, a interação humano-robô se torna mais importante dentro do processo de uma operação colaborativa (KRÜGER; LIEN; VERL, 2009).

Como esta pesquisa trata da robótica colaborativa na indústria, a área de conhecimento para levantar os artigos acadêmicos por meio dos periódicos científicos é a da engenharia. Como suporte, foi realizado um levantamento de artigos da literatura por meio da base Scopus, uma das maiores bases multidisciplinares de literatura científica e de estudos de engenharia (GERALDI et al. 2011). Os periódicos científicos constituem o meio mais importante para a comunicação científica. Graças a eles é que se torna possível a comunicação formal dos resultados de pesquisas originais e a manutenção do padrão de qualidade na investigação científica (GIL, 2002). A palavra-chave selecionada foi "operação colaborativa" ou “collaborative operation”. A seleção compreendeu o período entre 1990 a 2017 e apresentou a publicação de 1.262 artigos acadêmicos. Nela, percebe-se a relevância do tema na área acadêmica nos últimos anos, como indica a Figura 5. 
Figura 5: Pesquisa bibliográfica em relação à operação colaborativa

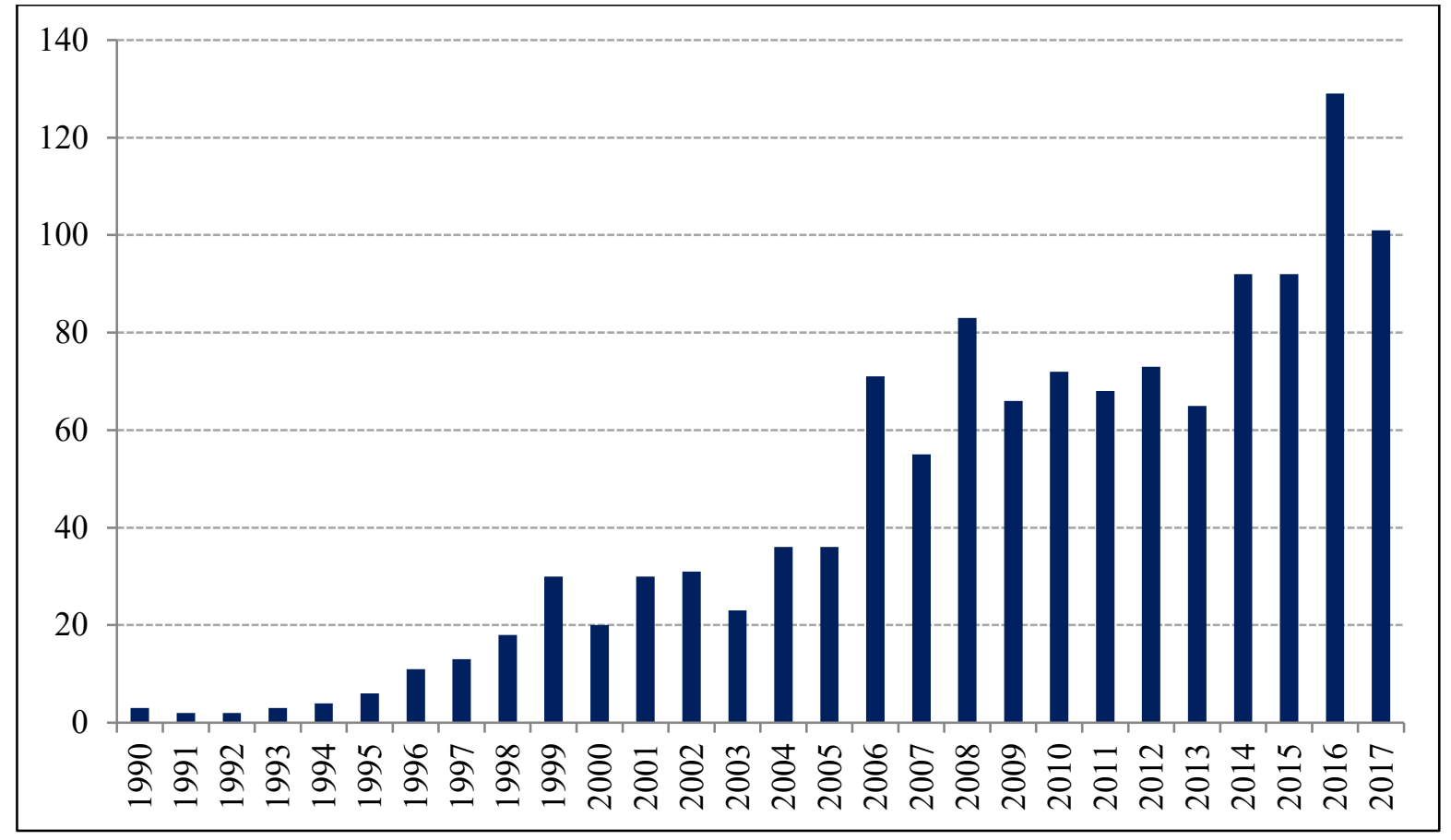

Fonte: Autor “adaptado de” Scopus, 2017

Em geral, os processos de manufatura se movem de linhas de produção estáticas, convencionais, não flexíveis e com grandes tamanhos de lotes para linhas de produção mais flexíveis e facilmente adaptáveis para fabricar, montar lotes pequenos ou mesmo para fazer operações de montagem customizadas (LOTTER, 2012; HEILALA; VOHO, 2001). Para acompanhar as evoluções dos processos de manufatura, a tecnologia robótica muda seu foco de aplicações industriais para aplicações com foco no operador. Por isso, nos últimos anos surge um interesse pela interação física entre humano-robô dentro da pesquisa robótica.

A operação colaborativa faz parte dos novos paradigmas na robótica industrial, que não exigem separação física entre manipuladores robóticos e humanos. Além disso, espera-se, por meio da operação colaborativa, a oportunidade de otimizar a produção e fazer com que humanos e robôs colaborem de modo harmônico (ZANCHETTIN et al., 2016). Trata-se de alcançar o objetivo de se obter um ambiente colaborativo no qual humanos e robôs trabalhem lado a lado e compartilhem tarefas complexas em um posto de trabalho aberto e sem proteção para os humanos (IBARGUREN et al., 2015).

Da mesma forma, Zanchettin et al. (2016), Charalambous, Fletcher e Webb (2015) argumentam que ao combinar as vantagens entre operadores e robôs iremos nos direcionar para o desenvolvimento da colaboração entre humanos e robôs na indústria, pois dentro da robótica colaborativa, esta é uma questão-chave para desenvolver fábricas do futuro, com espaços para 
humanos e robôs trabalharem e realizarem tarefas conjuntas (GROOVER, 2017; IBARGUREN et al., 2015).

Os avanços na interação humano-robô provêm também da necessidade de se atingir maior eficiência e maior produtividade, bem como de reduzir o estresse humano, ao diminuir sua carga de trabalho (MICHALOS et al., 2015). Aponta-se também o aumento da produtividade e da qualidade do produto como ganhos dessa interação (CHARALAMBOUS; FLETCHER; WEBB, 2015). O objetivo final é reduzir a fadiga, aumentar o poder e melhorar a qualidade do cotidiano dos humanos em geral e dos idosos em particular (PERVEZ; RYU, 2008). A operação colaborativa se baseia, portanto, em tentativas de melhorar a alocação e coordenação de tarefas entre humanos e robôs e pertence à ampla área de robótica interativa que visa a manufatura avançada (TSAROUCHI; SOTIRIS; CHRYSSOLOURIS, 2016; CHARALAMBOUS; FLETCHER; WEBB, 2015).

\subsubsection{Características da operação colaborativa}

Tsarouchi, Sotiris e Chryssolouris (2016) afirmam que uma operação colaborativa agrega valor, pois mantém o custo de produção favorável e combina as habilidades de humanos e robôs. A operação colaborativa melhora os indicadores de qualidade, competência, retrabalho, flexibilidade, eficiência e ergonomia, além de manter o tempo de ciclo e o espaço necessário similares aos do posto de trabalho manual (TSAROUCHI; SOTIRIS; CHRYSSOLOURIS, 2016; SCHOLER; VETTE; RAINER， 2015; KRÜGER; LIEN; VERL， 2009; THIEMERMANN, 2004).

Groover (2017) e Scholer, Vette e Rainer (2015) defendem que para se utilizar a colaboração entre o humano e o cobot em tarefas de montar se faz necessário aplicar as melhores qualidades de ambos, tais como: precisão para montar e coordenar tarefas, agilidade para manipular produtos, entre outras. Para alcançar o máximo potencial da colaboração física entre ambos, deve-se planejar a divisão do trabalho (SCHOLER; VETTE; RAINER, 2015; THIEMERMANN, 2004;).

Em complemento, Charalambous, Fletcher e Webb (2015) propõem que a estreita ligação do humano e do cobot em tarefas de montar na operação colaborativa deve fazer uso dos seus respectivos atributos. O Quadro 4 apresenta a distribuição das habilidades e características específicas do operador e do cobot para combinar os melhores atributos e alcançar maior eficiência no processo. 
Quadro 4: Distribuição de habilidades entre cobot e operador

\begin{tabular}{|l|l|}
\hline Cobot & Operador \\
\hline$\checkmark$ Muito repetitivo & $\begin{array}{l}\checkmark \text { Tarefas exigem altas habilidades cognitivas } \\
\text { /raciocínio }\end{array}$ \\
$\checkmark$ Movimentos simples & $\checkmark$ Movimentos complexos e destreza \\
$\checkmark$ Verificação visual elementar & $\checkmark$ Verificação visual complicada \\
$\checkmark$ Confiável, tomada de decisão direta & $\checkmark$ Tomada de decisão elaborada \\
$\checkmark$ Tarefas padronizadas, relativas a diferentes \\
$\quad \begin{array}{l}\text { variantes e modelos } \\
\text { modelos mistos e eventos inesperados }\end{array}$
\end{tabular}

Fonte: Autor "adaptado de" Scholer, Vette; e Rainer, 2015

Além dos atributos do operador e do cobot, Thiemermann (2004) e Scholer, Vette e Rainer (2015) explicam que se planeja o processo mais adequado para cada um dos parceiros durante a interação entre ambos, conforme suas características individuais. Segundo os autores, o conceito da colaboração entre humanos e robôs em tarefas de montagem cooperativa deve considerar o emprego das qualidades de ambos os lados.

Com base na divisão do trabalho, a operação colaborativa permite que o cobot seja o responsável pelas operações repetitivas, de precisão e insalubres, deixando as operações de raciocínio, destreza e coordenação para o operador (CERIANI et al., 2015). O Quadro 5 indica os principais benefícios derivados do processo de divisão do trabalho, em termos de custos, tempo e qualidade. Thiemermann (2004) e Scholer, Vette e Rainer (2015) comparam os benefícios entre um posto de trabalho manual e uma operação colaborativa. Os autores explicam que devido à alta confiabilidade de um sistema robótico e à exclusão de erros humanos, o nível de qualidade e a capacidade do processo aumentam.

Um trabalhador humano possui maior capacidade de adaptação e capacidade sensóriomotora. O conceito de colaboração humano-robô combina, em essência, as vantagens dos robôs industriais e dos trabalhadores humanos. Em um sistema de colaboração humano-robô, os trabalhadores humanos e os robôs industriais se unem e trabalham em conjunto na mesma tarefa compartilhada (CERIANI et al., 2015). De acordo com as instruções de trabalho, certos movimentos de um trabalhador humano são previsíveis. No entanto, para apoiar e colaborar com o humano no nível da tarefa, um robô industrial precisa trabalhar e coexistir ao lado deste trabalhador humano. 
Quadro 5: Principais benefícios da cooperação direta entre humano e cobot

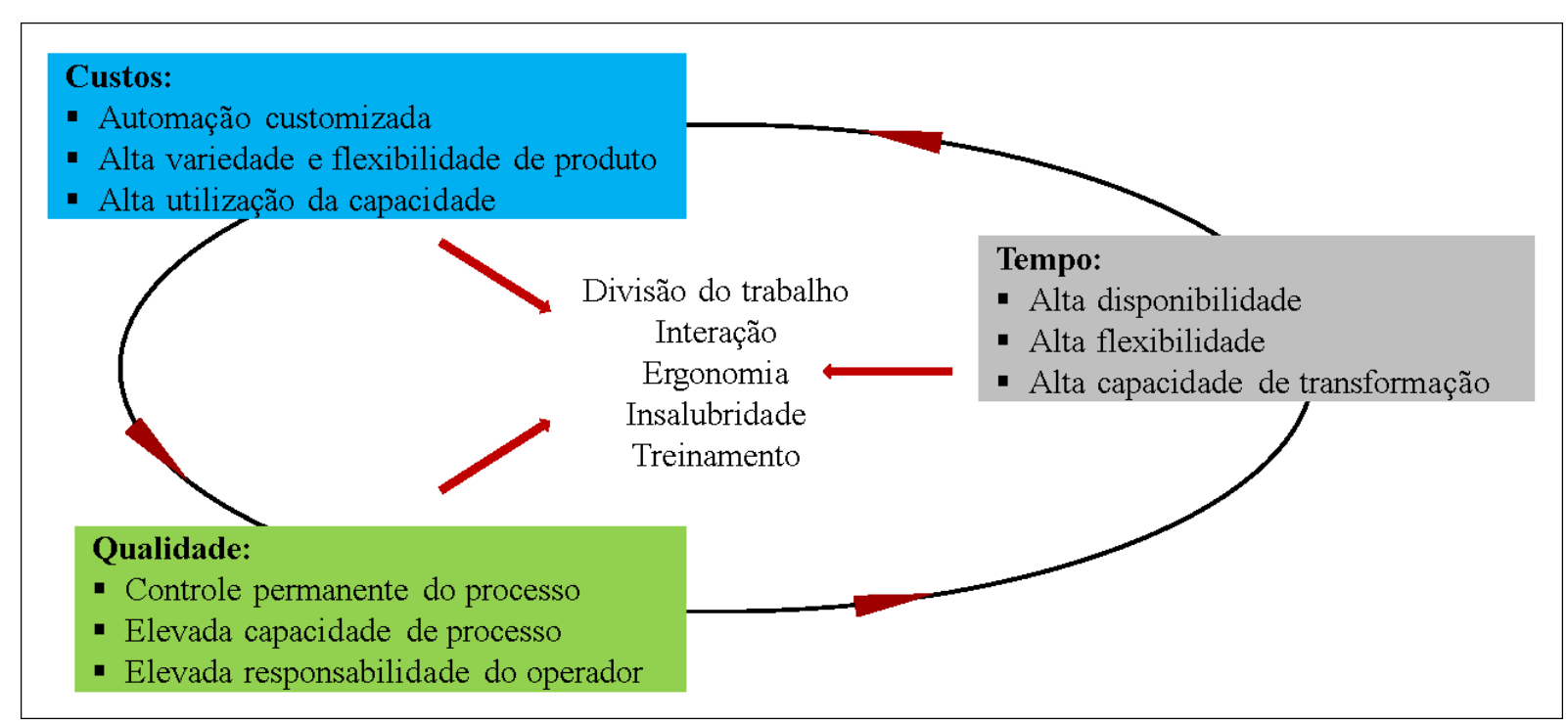

Fonte: Autor "adaptado de" Thiemermann, 2004, p. 38

O Quadro 6 apresenta uma comparação dos principais benefícios entre a operação colaborativa e um posto de trabalho manual (SCHOLER; VETTE; RAINER, 2015; THIEMERMANN, 2004;). Em relação aos indicadores de processo deste posto de trabalho, o sinal $(+)$ indica maior benefício da operação colaborativa em relação ao posto manual.

Quadro 6: Comparação de benefícios entre posto de trabalho manual e colaborativo

\begin{tabular}{|c|c|c|}
\hline Indicador & Operação manual & Operação colaborativa \\
\hline Nível de qualidade & $(-)$ & $(+)$ \\
\hline Capacidade do processo & $(-)$ & $(+)$ \\
\hline Necessidade de retrabalho & $(-)$ & $(+)$ \\
\hline Satisfação do cliente & $(-)$ & $(+)$ \\
\hline Investimento & $(+)$ & $(-)$ \\
\hline Manutenção do robô & $(+)$ & (-) sem manutenção intensiva \\
\hline Capacidade do operador & $(+)$ & (-) treinar, ajustar \\
\hline Flexibilidade & $(-)$ & $(+)$ \\
\hline Tempo de ciclo & $(-)$ & $(+)$ tarefas do robô mais ágil \\
\hline Necessidade de espaço & - & - \\
\hline Eficiência & $(-)$ & $(+)$ \\
\hline Ergonomia da estação & $(-)$ & $(+)$ \\
\hline Insalubridade & $(-)$ & $(+)$ \\
\hline Divisão do trabalho & - & - \\
\hline
\end{tabular}

Fonte: Scholer, Vette e Rainer, 2015 
Dentro do compartilhamento da área colaborativa, Groover (2017, p.15) define que "os humanos possuem certos atributos que lhes dão uma vantagem sobre os cobots em determinadas situações e certos tipos de tarefas." O Quadro 7 apresenta uma comparação das qualidades entre ambos em uma operação colaborativa.

Quadro 7: Qualidades de humanos e cobots em uma operação colaborativa

\begin{tabular}{|l|l|}
\hline Humano & Cobot \\
\hline Sentir estímulos inesperados & Executar tarefas repetitivas consistentemente \\
\hline Desenvolver novas soluções para problemas & Armazenar grandes quantidades de dados \\
\hline Lidar com problemas abstratos & Recuperar dados da memória de forma confiável \\
\hline Adaptar-se às mudanças & Executar múltiplas tarefas ao mesmo tempo \\
\hline Generalizar a partir de observações & Aplicar força e potência elevadas \\
\hline Aprender com a experiência & Executar cálculos simples rapidamente \\
\hline $\begin{array}{l}\text { Tomar decisões difíceis com base em dados } \\
\text { incompletos }\end{array}$ & Realizar as decisões de rotina rapidamente \\
\hline
\end{tabular}

Fonte: Groover, 2017

De maneira geral, em um posto de trabalho colaborativo, de acordo com Krüger, Lien e Verl (2009), o operador proporciona capacidades senso-motoras incomparáveis para tarefas complexas de manuseio, pode se adaptar de maneira rápida a novas sequências de processos, mas é restrito em força e precisão para montar. Contudo, em comparação com o cobot, o operador pode se sentir cansado durante a operação de montar. Desta maneira, a fadiga pode produzir um declínio no desempenho, como uma velocidade de reação lenta, falta de resposta às mudanças e a incapacidade de se concentrar e tomar decisões (CHEN et al., 2014).

\subsubsection{Segurança na operação colaborativa}

As limitações da colaboração entre humanos e robôs industriais em grande parte são devidas às preocupações com segurança ou com lesões que o operador humano pode sofrer (CHARALAMBOUS; FLETCHER; WEBB, 2015). Entre muitos aspectos tecnológicos, a segurança representa o problema central de um posto de trabalho colaborativo (PEDROCCHI et al., 2013). 
O interesse da comunidade de pesquisa em aspectos da interação entre humanos e robôs é proporcional ao aumento do número de publicações científicas. As bases de dados on-line ou serviços de resumo e indexação que fornecem acesso a artigos de periódicos, documentos em trabalhos de conferência, relatórios, dissertações e outros documentos são um recurso para localizar fontes de informação (ROWLEY; SLACK, 2004). Por meio da palavra-chave "interação humano-robô" ou "human robot interaction" (HRC), realizou-se uma busca na base de pesquisa bibliográfica Scopus. Foram encontrados 2.553 artigos acadêmicos entre 1974 a 2017, como mostra a Figura 6.

Figura 6: Pesquisa bibliográfica em relação à interação humano-robô

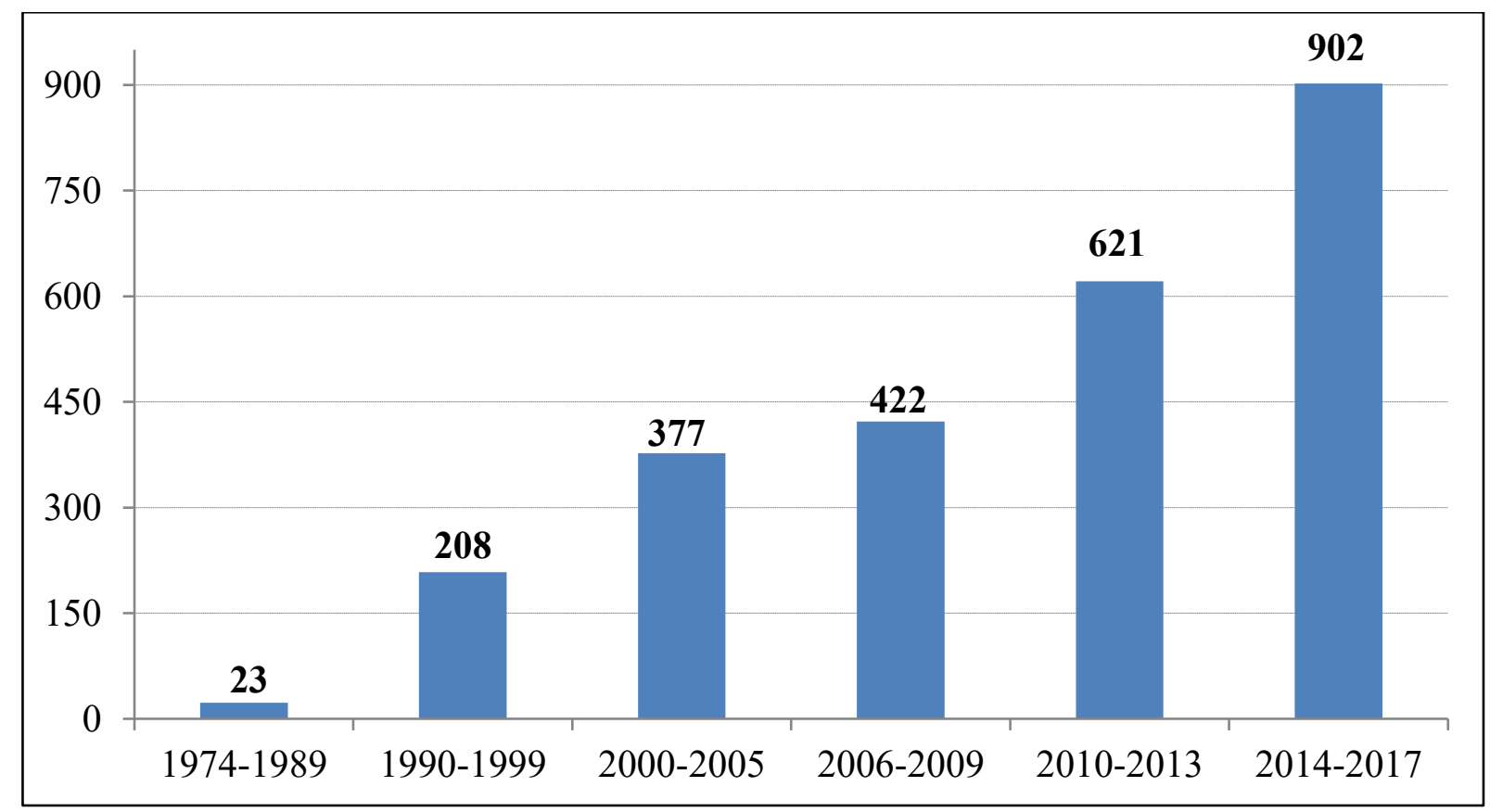

Fonte: Autor “adaptado de” Scopus, 2017

Através da base de dados Scopus, utilizaram-se as palavras-chave; "segurança e perigo" ou "safety and hazard" para poder identificar e classificar os aspectos relacionados à interação humano-robô em uma operação colaborativa, mencionados na literatura.

De acordo com o levantamento bibliográfico para este estudo conforme indica a Tabela 1, identifica-se que os níveis de interação ou tipos de operação colaborativa, os sistemas híbridos, o treinamento de pessoas, o planejamento do posto de trabalho e os sistemas cognitivos constituem os aspectos principais em uma operação colaborativa, em relação à segurança e ao perigo durante a interação humano-robô. Como suporte ao levantamento bibliográfico, um mapa bibliométrico foi elaborado, utilizando os recursos do software VOSviewer. 
Tabela 1: Pesquisa bibliográfica relacionada a uma operação colaborativa

\begin{tabular}{|c|c|c|c|c|c|c|}
\hline \multicolumn{2}{|c|}{ Aspectos } & \multicolumn{2}{|c|}{ Palavras-chave } & \multirow{2}{*}{$\begin{array}{c}\text { Artigos } \\
1\end{array}$} & \multicolumn{2}{|c|}{$\%$} \\
\hline \multirow{19}{*}{ 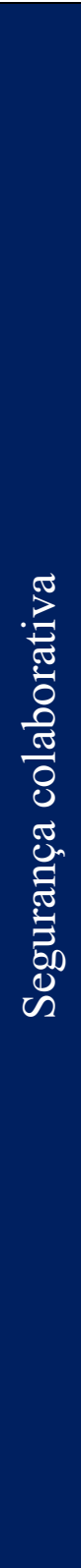 } & \multirow{8}{*}{ 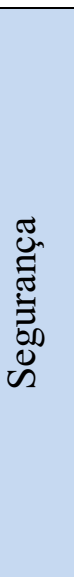 } & Collision & Colisão & & \multirow{13}{*}{$\begin{array}{l}59 \\
\%\end{array}$} & \multirow{13}{*}{ 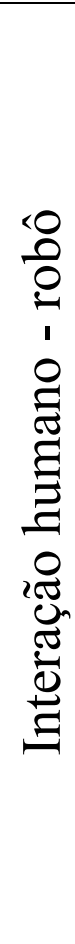 } \\
\hline & & Protection level & Nível de proteção & 9 & & \\
\hline & & ISO/TS 15066 & ISO/TS 15066 & 27 & & \\
\hline & & Safety of machinery & Segurança das máquinas & 33 & & \\
\hline & & Hazards & Perigos & 35 & & \\
\hline & & ISO & ISO & 36 & & \\
\hline & & Risk assessment & Análise de risco & 53 & & \\
\hline & & Safety & Segurança & 436 & & \\
\hline & \multirow{5}{*}{ 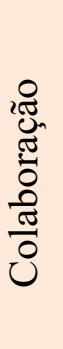 } & Task \& workplace & Atividades e posto de trabalho & 6 & & \\
\hline & & $H R C$ & Colaboração humano-robô & 238 & & \\
\hline & & Task planning & Planejamento de ações & 422 & & \\
\hline & & Training & Treinamento & 452 & & \\
\hline & & Level of interaction & Níveis de interação & 600 & & \\
\hline & \multirow{2}{*}{$\begin{array}{l}n \\
0 \\
0 \\
2\end{array}$} & COBOT & Robô colaborativo & 267 & \multirow{6}{*}{$\begin{array}{l}41 \\
\%\end{array}$} & \multirow{6}{*}{ 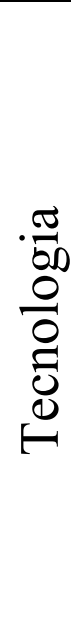 } \\
\hline & & Hybrid systems & Sistemas híbridos & 346 & & \\
\hline & \multirow{4}{*}{ 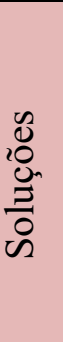 } & Visual guidance & Orientação visual & 104 & & \\
\hline & & Voice interaction & Interação de voz & 165 & & \\
\hline & & $\begin{array}{l}\text { Imitation and } \\
\text { learning }\end{array}$ & Imitação e treinamento & 180 & & \\
\hline & & Cognitive systems & Sistemas cognitivos & 600 & & \\
\hline
\end{tabular}

Fonte: Autor “adaptado de” Scopus, 2017

Identificam-se na Tabela 1 os seguintes construtos em relação às palavras-chave utilizadas na pesquisa dos artigos acadêmicos sobre a operação colaborativa para este estudo:

a) Interação: segurança, níveis de interação;

b) Tecnologia: sistemas híbridos e sistemas cognitivos. 
A implantação da colaboração entre humanos e robôs em sua amplitude irá permitir que as empresas se posicionem de maneira competitiva no mercado e possibilitará a evolução da manufatura avançada (KOOTBALLY, 2016; MURASHOV; HEARL; HOWARD, 2016; WANG, 2015; CHARALAMBOUS; FLETCHER; WEBB, 2015). Entretanto, além dos aspectos da manufatura avançada, da sustentabilidade no meio ambiente, na sociedade e na economia, as questões relacionadas à segurança e ao bem-estar dos operadores na manufatura ganham atenção (WANG, 2015; SCHOLER; VETTE; RAINER, 2015; VASIC; BILLARD, 2013; MARVEL, 2013; HARPER; VIRK, 2010).

A necessidade de cooperação entre humanos e robôs aumenta, de maneira especial nas aplicações da manufatura avançada. No entanto, a segurança humana é a principal preocupação na colaboração entre humanos e robôs industriais (BDIWI; PFEIFER; STERZING, 2017; MURASHOV; HEARL; HOWARD, 2016; CERIANI et al., 2015; PEDROCCHI et al., 2013). A partilha do espaço de trabalho sem qualquer dano que resulte aos operadores e ao próprio robô é o objetivo da pesquisa no domínio das interações físicas e cognitivas entre ambos (MURASHOV; HEARL; HOWARD, 2016).

Djuric, Urbanic e Rickli (2016) enfatizam que implementar os cobots na manufatura requer uma análise precisa das questões de segurança do trabalho potenciais, causadas pela interação próxima entre os operadores e os cobots. A maioria dos robôs pode causar ferimentos graves no trabalhador, ao entrar em contato com ele durante o processo de trabalho (GASKILL; WENT, 1996; MARVEL, 2013). Porém, com os recentes avanços tecnológicos, há uma tendência a unir de forma segura a potência e a precisão dos robôs com a inteligência para a resolução de problemas dos humanos, o que poderá aumentar a produtividade da indústria, por meio da operação colaborativa (HOLDER et al., 2016). Diante deste horizonte, Guiochet, Machin e Waeselynck (2017) afirmam que o desenvolvimento técnico das funções da robótica e as melhoras tecnológicas estão próximos de se tornarem realidade.

Mas uma questão se coloca: qual é a confiança humana nesses sistemas? Um dos principais aspectos para se estabelecer a confiança é garantir a segurança dos operadores, devido ao fato de que a segurança é um tema fundamental ao implantar-se os cobots (GUIOCHET; MACHIN; WAESELYNCK, 2017). Portanto, quando um robô interage de maneira física com o ser humano, os requisitos se modificam de maneira drástica, no sentido de que o robô não deve prejudicar o ser humano em nenhuma situação (PERVEZ; RYU, 2008).

No âmbito da interação humano-robô, Navarro et al. (2016) propõem que se deve alcançar níveis de segurança elevados, quando ocorre o contato físico entre o operador e o robô. Para a operação colaborativa, a interação entre operador e robô, o robô deve se comportar com 
segurança, de maneira especial quando um operador está presente em seu espaço de trabalho (NAVARRO et al., 2011). Ainda com relação à operação colaborativa, Vasic e Billard (2013) explicam que existem duas categorias principais de lesões trabalhistas em torno dos cobots, devido a erros de engenharia e a erros humanos. Segundo os autores, os erros de engenharia incluem erros na mecânica do robô (por exemplo, conexões soltas entre peças, eletrônicos defeituosos) e erros cometidos pelo controlador (por exemplo, erros de programação, algoritmo defeituoso). Como consequência, os cobots podem, por exemplo, parar de atuar, ou um braço do cobot pode alcançar uma velocidade alta, de maneira descontrolada e com movimento ou aceleração abrupta.

Como a presença humana constante dentro ou perto da área de trabalho do robô inteligente leva a uma mudança em relação à segurança (KHALID et al., 2016), Hull e Minarcin (2016) advogam que agora novas considerações com a segurança humana podem incluir lesões por colisão junto à garra de manipulação, emaranhamento de cabos elétricos no piso, contusões devido ao desprendimento de peças do braço do cobot, cortes no corpo do operador, devido às bordas afiadas das garras de manipulação, e esmagamento de alguma parte do corpo, devido ao seu aprisionamento em estruturas circundantes.

Contudo, diante de todos os aspectos tecnológicos para a segurança em uma operação colaborativa, Bertolini et al. (2016) afirmam que ainda não ficou claro se o cobot pode aumentar ou reduzir a segurança dos humanos que interagem com ele. Segundo os autores, embora os cobots tenham como objetivo executar as tarefas que lhe são atribuídas por serem mais seguras para eles do que para o ser humano que o substitui ou ajuda, não é possível excluir a possibilidade da ocorrência de um evento perigoso. Por isso, durante a interação entre o ser humano e o cobot, o robô deve se movimentar com segurança, especialmente quando um operador está presente em seu espaço de trabalho (NAVARRO et al., 2016).

\subsection{PADRÕES PARA UTILIZAÇÃO DOS ROBÔS COLABORATIVOS}

Existem instituições que padronizam a segurança na interação humano-robô, sendo as mais influentes a International Organization for Standardization (ISO) e o American National Standards Institute (ANSI). Os padrões emergentes, entre os quais os comitês técnicos da ISO (2011) que fornecem definições sobre o trabalho colaborativo, podem possibilitar a ampliação da gama de aplicações do cobot, ao compartilhar o espaço de trabalho e cooperar com o operador (PEDROCCHI et al., 2013). 
Charalambous, Fletcher e Webb (2015) explicam que a ISO (2011) define a colaboração entre humanos e robôs como um tipo especial de operação entre um operador e um robô que compartilham um espaço de trabalho comum.

Ainda que se considere que as preocupações com segurança inibem a absorção dos cobots, deve-se notar que as sofisticadas tecnologias de segurança em desenvolvimento ajudam a reduzir essas preocupações (BOGUE, 2016). Em termos de concepção, os manipuladores robóticos devem aderir aos padrões internacionais estabelecidos para segurança de robôs (MARVEL et al., 2015). Quanto ao foco na segurança do operador, os padrões internacionais de segurança da ISO (2011) definem o uso de tarefas colaborativas dentro de uma área de trabalho predefinida, denominada de área de trabalho colaborativa (GOPINATH; JOHANSEN, 2016).

\subsubsection{Padrões internacionais}

Em relação à robótica colaborativa, a norma ISO 10218 - partes 1 e 2 (2011) é o conjunto de padrões relativos à segurança para este tipo de robô (ZANCHETTIN et al., 2016),

Zanchettin et al. (2016), Murashov, Hearl e Howard (2016) e Matthias e Reisinger (2016) complementam que as normas ISO 10218 partes 1 e 2 (2011) se dividem em duas partes, sendo a ISO 10218 - parte 1 para orientação na concepção das características de segurança para os robôs industriais e a ISO 10218 - parte 2 para as características de segurança de sistemas de robô industrial. A norma ISO 10218 (2011) promove a implantação de sistemas de produção híbridos, ou seja, sistemas de produção que se caracterizam por uma estreita relação entre humanos e robôs em tarefas cooperativas (PEDROCCHI et al., 2013).

Em relação à operação colaborativa, Matthias e Reisinger (2016) afirmam que ao considerar implantar de maneira adequada os cobots, é útil ter uma visão geral dos padrões relevantes ao processo colaborativo. A hierarquia dos padrões de segurança para desenvolver a segurança em máquinas que Matthias e Reisinger (2016) mencionam se faz necessária para planejar uma célula automática ou uma célula colaborativa, conforme ilustra a Figura 7. Esses padrões se apresentam em conformidade com a norma ISO 10218: partes 1 e 2 (2011).

Ainda em relação à operação colaborativa, Matthias e Reisinger (2016), Tsarouchi, Sotiris e Chryssolouris (2016) e Shackleford et al. (2016) explicam que nos últimos anos os padrões de segurança do robô descrito na norma ISO 10218 são modificados para especificar requisitos que permitam que humanos e robôs trabalhem juntos em circunstâncias limitadas. 
Figura 7: Padrões de segurança para máquinas

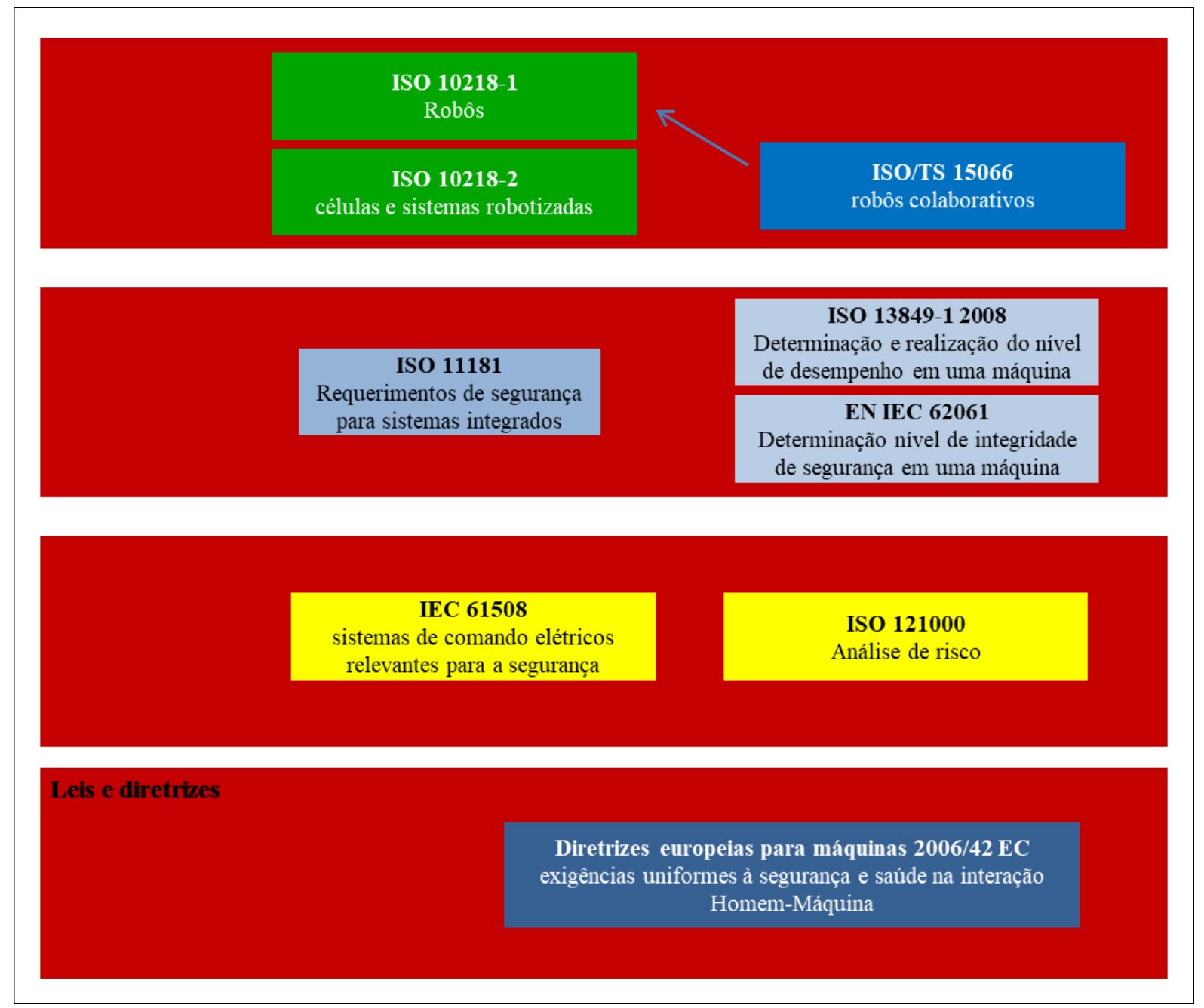

Fonte: Matthias e Reisinger, 2016

\subsubsection{Apreciação de risco}

A introdução dos cobots na indústria redefine os requisitos de segurança em uma célula automática. Muitos cobots têm projetos intrinsecamente seguros, de acordo com a norma de segurança internacional EN ISO 12100 (2010), adotada como medida para eliminar ou reduzir riscos. Contudo, faz-se necessário realizar uma análise de apreciação de risco, quando se concebe uma operação colaborativa, pois a integração de equipamentos em um ambiente fabril com os humanos requer que se comprove o nível de segurança, bem como demanda uma melhor compreensão da natureza e dos riscos da colaboração entre humanos e robôs (MARVEL, 2013). Gopinath e Johansen (2016) explicam que a apreciação de riscos considera os humanos e os cobots como participantes válidos para garantir a segurança dos operadores e a produtividade da estação de trabalho. Fontes de riscos incluem, mas não se limitam a erros humanos, erros de 
controle, acesso não autorizado, falhas mecânicas, fontes ambientais, sistemas de energia e instalação e projeto inadequado (HULL; MINARCIN, 2016).

Ainda de acordo com o padrão da EN ISO 12000 (2010), a apreciação de risco é o primeiro passo para entender e eliminar o ambiente de trabalho perigoso (GOPINATH; JOHANSEN, 2016). Esta apreciação aplica-se durante as operações colaborativas e deve dedicar especial atenção às tarefas em que o contato entre o cobot e o operador é possível (HULL; MINARCIN, 2016). Como requisito a essa apreciação, os equipamentos e seu uso dentro de uma fábrica devem seguir os padrões de segurança (CHINNIAH; AUCOURT; BOURBONNIÈRE, 2017; GOPINATH; JOHANSEN, 2016).

Bertolini et al. (2016) apontam que, da mesma forma que qualquer outro equipamento, os riscos gerados por um cobot podem se dividir em danos a uma pessoa, a objetos ou propriedades. No que diz respeito ao dano pessoal, os autores consideram dois tipos de danos que podem ocorrer ao se utilizar um cobot:

a) Danos leves;

b) Danos severos.

Segundo os autores os danos leves são danos mentais ou psicológicos, relacionados à mente. Podem afetar as capacidades cognitivas, sociais e mesmo emocionais de uma pessoa, sendo resultantes de interações prolongadas com tipos especiais de robôs.

Bicchi, Peshkin e Colgate (2008) definem que os danos severos são físicos, isto é, se relacionam ao corpo de uma pessoa e são causados pela interação física entre humanos e robôs. Os danos físicos provêm de defeitos no funcionamento correto de um robô e, portanto, são atribuídos ao fornecedor do robô (BERTOLINI et al., 2016).

Guiochet, Machin e Waeselynck (2017) explicam que após surgirem os robôs avançados com novas habilidades, como a autonomia para tomar decisão e interagir de maneira física com os humanos, considera-se agora a ocorrência de perigos que não sucediam com os robôs industriais tradicionais.

O Quadro 8 apresenta um comparativo entre a robótica industrial e a robótica colaborativa, no qual se destacam as características de autonomia e colaboração, bem como os riscos induzidos com a robótica colaborativa.

Guiochet, Machin e Waeselynck (2017) afirmam que a primeira preocupação ao se tratar com a segurança do robô é abordar a segurança dos operadores, devido ao contato físico. 
Quadro 8: Aspectos da interação na robótica e exemplos de novos riscos induzidos

\begin{tabular}{|l|l|l|l|l|}
\hline $\begin{array}{c}\text { Aspectos da } \\
\text { interação } \\
\text { humano-robô }\end{array}$ & $\begin{array}{l}\text { Ações no posto } \\
\text { de trabalho em } \\
\text { relação a cada } \\
\text { tipo de robô }\end{array}$ & Robô industrial & Cobot & $\begin{array}{l}\text { Novos exemplos de riscos } \\
\text { para os humanos no posto de } \\
\text { trabalho colaborativo }\end{array}$ \\
\hline \multirow{4}{*}{ Autonomia } & $\begin{array}{l}\text { Controle do } \\
\text { robô }\end{array}$ & Automático & $\begin{array}{l}\text { Autonomia para } \\
\text { decidir }\end{array}$ & Decisões perigosas \\
\cline { 2 - 5 } & $\begin{array}{l}\text { Espaço de } \\
\text { trabalho }\end{array}$ & Estruturado & $\begin{array}{l}\text { Não estruturado } \\
\text { (incertezas) }\end{array}$ & $\begin{array}{l}\text { Situações adversas / } \\
\text { incertezas na percepção }\end{array}$ \\
\hline \multirow{5}{*}{ Colaboração } & $\begin{array}{l}\text { Movimento do } \\
\text { robô }\end{array}$ & $\begin{array}{l}\text { Sem movimento do } \\
\text { robô na presença } \\
\text { humana }\end{array}$ & $\begin{array}{l}\text { Movimento } \\
\text { simultâneo } \\
\text { (humano e robô) }\end{array}$ & $\begin{array}{l}\text { Má sincronização entre } \\
\text { humano e robố } \\
\text { movimentos não legíveis em } \\
\text { humanos }\end{array}$ \\
\cline { 2 - 5 } & $\begin{array}{l}\text { Proximidade } \\
\text { Humano-robô }\end{array}$ & Humano é afastado & $\begin{array}{l}\text { O ser humano é } \\
\text { próximo / Interação } \\
\text { física }\end{array}$ & $\begin{array}{l}\text { Colisões, alta força de } \\
\text { contato }\end{array}$ \\
\cline { 2 - 5 } & $\begin{array}{l}\text { Comunicação } \\
\text { Humano-robô }\end{array}$ & Dispositivo remoto & $\begin{array}{l}\text { Interação avançada } \\
\text { (cognitiva) }\end{array}$ & $\begin{array}{l}\text { Confusão de modo / erros de } \\
\text { comunicação }\end{array}$ \\
\hline \multirow{5}{*}{ Tarefa } & $\begin{array}{l}\text { Arquitetura } \\
\text { mecânica }\end{array}$ & $\begin{array}{l}\text { Pesado, rígido, } \\
\text { potente }\end{array}$ & $\begin{array}{l}\text { Leve, compatível, } \\
\text { com potência } \\
\text { limitada }\end{array}$ & $\begin{array}{l}\text { Perigos de precisão / } \\
\text { armazenamento devido à } \\
\text { conformidade }\end{array}$ \\
\cline { 2 - 5 } & $\begin{array}{l}\text { Complexidade } \\
\text { da tarefa }\end{array}$ & Mono-função & Multi-funções & $\begin{array}{l}\text { Regras de segurança não } \\
\text { adaptadas (regras diversas e } \\
\text { em evolução) }\end{array}$ \\
\hline
\end{tabular}

Fonte: Autor “ adaptado de" Guiochet, Machin e Waeselynck, 2017

Ao se considerar o fato de que um espaço de trabalho colaborativo não só envolve o operador e o robô, mas também outros dispositivos auxiliares (parafusadeiras elétricas, dispositivos de fixação elétricos), cada célula apresenta riscos únicos que necessitam ser administrados com segurança. A estreita interação entre humanos e cobots torna as restrições de segurança um dos aspectos mais significantes da arquitetura do robô. Eles incluem não apenas o objetivo de evitar colisões, mas também de investigar e minimizar as consequências das colisões causadas por movimentos rápidos ou imprevistos dos robôs (CORDERO et al.; 2014).

Os trabalhos que se realizam sobre danos induzidos por cobots são as análises biomecânicas de impacto humano, de contato com o cobot, esmagamento, corte, etc. e loop ou atuadores de controle que se associam para reduzir a gravidade do dano. Alguns resultados dessas pesquisas são parte da especificação técnica ISO/TS 15066 (GUIOCHET; MACHIN; WAESELYNCK, 2017).

\subsubsection{Documentação para a apreciação de risco}

Para poder efetivar e documentar uma apreciação de riscos, Djuric, Urbanic e Rickli (2016) explicam que uma fonte de segurança e de risco estruturada para a avaliação da 
segurança de um posto de trabalho colaborativo é o Occupational Safety and Health of the German Social Accident Insurance (BG/BGIA). Segundo os autores, o relatório do BG/BGIA divide a análise de segurança em uma lista composta de quatro etapas:

1. Padrões básicos e existentes: verificar as normas de segurança dos robôs conforme ISO 10218 - parte 1 e ISO 10218 - parte 2;

2. Cobot e atividades no local de trabalho: fornece especificações operacionais e de segurança do cobot, posição espacial e a descrição de todas as tarefas do operador e do robô que se executam no posto de trabalho;

3. Especificações do espaço colaborativo: identificar de maneira precisa o espaço de colaboração no local de trabalho e verificar as regiões específicas do corpo humano suscetíveis a risco de colisão durante a sequência de tarefas no posto de trabalho;

4. Registro de dados para atividades e desempenho do trabalho colaborativo: analisar o posto de trabalho através dos registros de requisitos técnicos, risco e ou gravidade de lesão, condições ergonômicas e a maneira de organizar o trabalho.

Espera-se que, ao completar a lista de verificação, sejam identificados e contabilizados durante a concepção das medidas de segurança os potenciais riscos de segurança associados ao cobot, ao humano, e às atividades, tarefas e ambiente de trabalho na célula (DJURIC; URBANIC; RICKLI, 2016).

Ainda sobre a elaboração da apreciação de risco, Chinniah, Aucourt e Bourbonnière (2017) e Gopinath e Johansen (2016) explicam que devem ser aplicadas metodologias de apreciação de risco que resultem em soluções que atendam aos seguintes requisitos de segurança:

a) EN ISO 12100 (2010), para segurança de máquinas - princípios gerais de projeto avaliação de riscos e redução de riscos. Define e enumera os requisitos e o procedimento para realizar a avaliação de risco;

b) ISO 10218 - parte 1, para orientação na concepção das características de segurança para os robôs industriais;

c) ISO 10218 - parte 2, para as características de segurança de sistemas de robô industrial.

Em complemento ao atendimento desses requisitos de segurança, Hull e Minarcin (2016) enfatizam que se deve avaliar os riscos de contato e colisão para as aplicações de cobots com base na especificação técnica ISO/ TS 15066 (2016): robôs e dispositivos robotizados robôs colaborativos. Segundo os autores, o integrador de sistemas deve realizar a apreciação de risco em conjunto com o usuário final, de maneira que esta avaliação deve ser uma tarefa em 
grupo e deve incluir os operadores e os especialistas em segurança. Djuric, Urbanic e Rickli (2016) argumentam que uma avaliação dos riscos antes de implementar os cobots é importante durante o projeto das células de trabalho e deve respeitar os padrões de segurança da especificação técnica ISO/TS 15066.

\subsubsection{Especificação técnica ISO/TS 15066}

A fim de desenvolver uma metodologia para avaliar a colaboração entre humanos e robôs industriais, foram publicados na Europa nos últimos anos padrões das normas ISO (2011), que incluem vários requisitos de segurança e que adequam o robô industrial para trabalhar com humanos em um mesmo espaço de trabalho (BDIWI; PFEIFER; STERZING, 2017). Desta maneira, elaborou-se a especificação técnica ISO/TS 15066 que aborda os cobots, de modo a permitir o uso deste tipo de robô em escala nas indústrias (VYSOCKY; NOVAK, 2016; MARVEL et al. 2015). A ISO/TS 15066 tem o objetivo de complementar as normas ISO 10218 (partes 1 e 2) e fornecer orientação adicional e métodos de segurança para a interação humanorobô (BDIWI; PFEIFER; STERZING, 2017). Segundo os autores, a especificação técnica ISO/TS 15066 visa reduzir restrições de contato na interação entre os humanos e os robôs.

Esta especificação técnica é uma ferramenta de estímulo à inovação e a investimentos na tecnologia da robótica colaborativa, pois orienta os projetistas e usuários de robôs industriais para ampliar a interação entre humanos e sistemas robóticos em ambientes industriais, bem como conciliar produtividade e segurança. Os trabalhos na ISO/TS 15066 se iniciam com a ideia de que, na eventualidade de haver qualquer contato acidental entre o humano e o cobot, não pode haver dor ou lesão nos operadores. Gopinath e Johansen (2016) abordam a ISO/TS 15066, em termos dos requisitos específicos de segurança para sistemas de robôs industriais colaborativos e o seu espaço de trabalho.

Esta especificação técnica destina-se a atuar como suplemento aos padrões de segurança do robô industrial (BDIWI; PFEIFER; STERZING, 2017). A ISO/TS 15066 menciona os padrões de segurança para atender os requisitos de uma operação colaborativa (GUIOCHET; MACHIN; WAESELYNCK, 2017; ANTONELLI; BRUNO, 2017) e fornece orientação adicional e métodos de segurança para a interação humano-robô, conforme métodos de operações colaborativas referenciados na literatura (BDIWI; PFEIFER; STERZING, 2017; DJURIC; URBANIC; RICKLI, 2016). O Quadro 9 mostra os aspectos de colaboração possíveis em uma operação colaborativa, descritos pela ISO/TS 15066 em relação a literatura. 
Quadro 9: Tipos de operação colaborativa mencionadas na literatura

\begin{tabular}{|c|c|c|c|}
\hline Tipo de colaboração & $\begin{array}{c}\text { ISO/TS } \\
15066\end{array}$ & Aspectos de colaboração & Autores \\
\hline $\begin{array}{l}\text { Parada monitorada } \\
\text { com classificação de } \\
\text { segurança }\end{array}$ & $\begin{array}{l}\text { Item } \\
5.5 .2\end{array}$ & $\begin{array}{l}\text { O robô colaborativo permanece fora do } \\
\text { espaço de trabalho colaborativo quando } \\
\text { o operador trabalha no espaço de } \\
\text { trabalho colaborativo } \\
\text { Limite no movimento do robô: ISO } \\
\text { 10218-1:2011, 5.12 } \\
\text { Parada protetiva: } 10218-1: 2011,5.5 .3\end{array}$ & $\begin{array}{l}\text { Djuric; Urbanic; Rickli } \\
\text { (2016); Hull; Minarcin } \\
\text { (2016); Antonelli; Bruno } \\
\text { (2017); Bdiwi; Pfeifer; } \\
\text { Sterzing (2017) }\end{array}$ \\
\hline $\begin{array}{l}\text { Operação guiada } \\
\text { manualmente }\end{array}$ & $\begin{array}{l}\text { Item } \\
5.5 .3\end{array}$ & $\begin{array}{l}\text { Operador utiliza a guia manual para } \\
\text { programar } \\
\text { Antes do operador adentrar a área } \\
\text { colaborativa, o cobot entra no modo de } \\
\text { parada monitorada de segurança } \\
\text { ISO/TS 15066:2016 (item 5.5.2) }\end{array}$ & $\begin{array}{l}\text { Djuric; Urbanic; Rickli } \\
\text { (2016); Hull; Minarcin } \\
\text { (2016); Antonelli; Bruno } \\
\text { (2017); Bdiwi; Pfeifer; } \\
\text { Sterzing (2017); Wang } \\
\text { (2015) }\end{array}$ \\
\hline $\begin{array}{l}\text { Monitoramento de } \\
\text { velocidade e separação } \\
\text { (SSM) }\end{array}$ & $\begin{array}{l}\text { Item } \\
5.5 .4\end{array}$ & $\begin{array}{l}\text { Velocidade e separação utilizando } \\
\text { zonas de segurança } \\
\text { Função de limite de velocidade e } \\
\text { espaço: ISO } 10218-1,5.6 .4 ; 5.11 .12 \text {; } \\
5.12 .3\end{array}$ & $\begin{array}{l}\text { Djuric; Urbanic; Rickli } \\
\text { (2016); Hull; Minarcin } \\
\text { (2016); Pervez; Ryu (2008); } \\
\text { Marvel, 2013; Bicchi; } \\
\text { Antonelli; Bruno (2017); } \\
\text { Pedrocchi et al. (2013); } \\
\text { Zanchettin et al. (2016); } \\
\text { Ceriani et al. (2015) }\end{array}$ \\
\hline $\begin{array}{l}\text { Limitação de potência } \\
\text { e força (PFL) }\end{array}$ & $\begin{array}{l}\text { Item } \\
5.5 .5\end{array}$ & $\begin{array}{l}\text { Aplicação de limitação de potência e } \\
\text { força onde o operador e o robô têm } \\
\text { potencial para contato } \\
\text { Redução de riscos: ISO/TS } \\
\text { 15066:2016, (análise de impactos } \\
\text { contra diversas regiões do corpo } \\
\text { humano); } \\
\text { Parâmetros de força e ergonomia: ISO } \\
\text { 10218-1, 5.11.5.5 }\end{array}$ & $\begin{array}{l}\text { Djuric; Urbanic; Rickli } \\
\text { (2016); Hull; Minarcin } \\
\text { (2016); Bicchi; Marvel, } \\
\text { 2013; Antonelli; Bruno } \\
\text { (2017); Bdiwi; Pfeifer; } \\
\text { Sterzing (2017) }\end{array}$ \\
\hline
\end{tabular}

Fonte: Autor “ adaptado de“ Hull e Minarcin, 2016

Conforme os autores, a ISO/TS 15066 categoriza quatro tipos de métodos para uma operação colaborativa: 


\subsubsection{Parada monitorada com classificação de segurança}

A especificação técnica ISO/ 15066 na cláusula 5.5.1 denomina este tipo de operação colaborativa de parada monitorada com classificação de segurança ou safety rated monitored stop. Nesta aplicação, equipa-se o cobot com a função de parada monitorada de segurança que causa uma parada protetora antes que o operador entre no espaço de trabalho colaborativo.

Hull e Minarcin (2016) explicam que os sensores no sistema de controle de segurança detectam a presença humana e de maneira imediata param o movimento do cobot, caso um operador fique muito próximo do mesmo. Segundo os autores, isso se utiliza quando os operadores e os cobots trabalham em proximidade ou com sobreposição do envelope de trabalho. Quando ocorre a parada monitorada com classificação de segurança, também não se habilita o robô a entrar no espaço de trabalho colaborativo enquanto o operador estiver dentro dessa área (BDIWI; PFEIFER; STERZING, 2017), pois a função monitorada de segurança é ativada e o movimento do cobot interrompido. Neste caso, sensores de segurança definem uma distância segura entre o cobot e o operador, pois não se permite o movimento do cobot quando um operador está no espaço de trabalho colaborativo (DJURIC; URBANIC; RICKLI, 2016; HULL; MINARCIN, 2016). Neste tipo de método de operação colaborativa, um operador pode carregar peças de maneira direta na garra de manipulação do cobot, enquanto o mesmo está em uma condição de parada segura. Isso ajuda na melhora da produtividade, porque a célula pode continuar em funcionamento de maneira independente do cobot (HULL; MINARCIN, 2016).

\subsubsection{Operação guiada manualmente}

A especificação técnica ISO/TS 15066 na cláusula 5.5.2 denomina este tipo de operação colaborativa de operação guiada de maneira manual ou hand guiding.

Utiliza-se a guia manual principalmente para ensinar ou reatar as posições do cobot (HULL; MINARCIN, 2016). Apenas se permite o movimento do cobot gerado pelo operador (DJURIC; URBANIC; RICKLI, 2016), dando ao mesmo o controle e a capacidade de manter uma operação segura (HULL; MINARCIN, 2016). Neste modo de operação, se o operador entra no espaço de trabalho colaborativo, então o sistema do cobot ativa a função parada monitorada de segurança. Nesta condição, o operador tem a possibilidade de acionar um dispositivo de guia para iniciar o movimento do robô. O movimento do robô também pode responder aos comandos humanos (BDIWI; PFEIFER; STERZING, 2017). 
Um método menos comum do que o monitoramento com classificação de segurança permite aos operadores controlar de maneira manual ou reposicionar o robô para a próxima tarefa. Neste caso, o operador está em contato direto com o braço do cobot e pode utilizar controles manuais para reposicioná-lo. Não é um método recomendado para tarefas que exigem altas velocidades (HULL; MINARCIN, 2016).

\subsubsection{Monitoramento de velocidade e separação}

A especificação técnica ISO/TS 15066 na cláusula 5.5.3 denomina este tipo de operação colaborativa de monitoramento de velocidade e separação ou speed and separation monitoring (SSP).

As aplicações de velocidade e separação utilizam uma distância de proteção e separação proativa para controlar a distância entre a velocidade monitorada de segurança, a parada habilitada do cobot e o operador, conforme recomenda a ISO/TS 15066. No monitoramento de velocidade e separação, a velocidade do cobot se correlaciona de maneira direta com a distância de separação segura entre o cobot e o operador. Sempre que a distância for menor, o cobot deve ser mais lento (BDIWI; PFEIFER; STERZING, 2017). Evitar colisões é basicamente um conjunto de procedimentos para organizar o movimento do robô na presença de obstáculos dinâmicos, no caso específico do operador (PEDROCCHI et al., 2013). Um conjunto simples de restrições na velocidade do cobot aplica-se para cumprir os regulamentos impostos pelo critério mínimo de distância de separação. Utiliza-se esta restrição em tempo real para limitar a velocidade do cobot, que depende também da distância em relação ao operador, conforme detectada através do sistema de segurança embarcado no cobot. (ZANCHETTIN et al., 2016).

A execução de algoritmos seguros para evitar colisão depende de sensores distribuídos nos eixos dos cobots que retornam com a posição e o movimento dos obstáculos (PEDROCCHI et al., 2013). De acordo com Hull e Minarcin (2016) este método permite que operadores e cobots trabalhem no mesmo espaço e mantenham uma distância segura entre si. Se um operador chegar muito perto de um cobot, os sensores irão alertar o robô para diminuir a velocidade ou parar (HULL; MINARCIN, 2016; BICCHI; PESHKIN; COLGATE, 2008).

Nos sistemas robotizados centrados no ser humano, espera-se que as métricas de velocidade e separação se concentrem na preservação da segurança humana em um ambiente compartilhado para a conclusão de uma determinada tarefa. No entanto, não se pode ignorar a preocupação com a velocidade necessária para atingir o tempo de ciclo imposto ao cobot para a conclusão da tarefa, pois altas velocidades para se atingir os volumes de produção solicitados 
na tarefa podem impor riscos aos humanos e inviabilizar a aplicação com o cobot (MARVEL, 2013). A garantia de evitar uma colisão em sua totalidade ainda é um desafio para os fabricantes de robôs industriais. Isto se deve ao fato de que as técnicas de prevenção de colisões lidam com a segurança antes da colisão e não se concentram na redução da principal causa de lesão, a força de impacto (PERVEZ; RYU, 2008).

\subsubsection{Limitação de potência e força}

A especificação técnica ISO/TS 15066 na cláusula 5.5.4 denomina este tipo de operação colaborativa de limitação de potência e força ou power and force limiting (PFL).

Nas aplicações de limite de potência de força, é necessário que o robô seja projetado de maneira específica para este tipo de aplicação. As referências mais comuns para este tipo de robô são os cobots, conforme recomenda a ISO 10218 - partes 1 e 2. Quando da limitação de potência e força, o contato incidental, que se inicia pelo cobot, deve ter limitação de impacto para evitar danos ao operador. Isso também significa que o projeto do cobot elimine bordas afiadas em suas articulações e proteja os seus pontos de aperto (BDIWI; PFEIFER; STERZING, 2017). Além disso, o cobot deve ser capaz de cumprir as tarefas planejadas pelos humanos e reagir após o contato e efetuar a sua movimentação de forma imediata. Com este método, se um cobot entrar em contato de maneira acidental com um humano, o cobot reduz sua força ou torque para que o operador não sofra acidentes. Este é um método emergente e o menos comum que se implementa. O cobot precisa realmente entrar em contato com um humano antes de reconhecer que necessita parar seus movimentos (HULL; MINARCIN, 2016).

Dentro do domínio da robótica colaborativa industrial, avalia-se a segurança de um cobot pela limitação de potência e força, o que minimiza o potencial de lesão no operador após o impacto do cobot, com base em padrões de lesões estabelecidos (BICCHI; PESHKIN; COLGATE, 2008; MARVEL, 2013). A implantação deste método requer a compreensão da relação entre diferentes níveis de força e limiares de dor em várias partes do corpo humano (HULL; MINARCIN, 2016). A potência e a força se limitam por estratégias inerentes do projeto ou controle. Aqui existem forças estáticas e dinâmicas que se limitam no caso de contato (DJURIC; URBANIC; RICKLI, 2016). Caso o cobot não esteja em situação de impacto com um obstáculo, não se deve dificultar o seu movimento além das restrições físicas normais que se limitam pela sua tarefa. No entanto, se um obstáculo estiver presente, devem-se reduzir as velocidades das articulações do robô para limitar a força e a potência em uma colisão acidental (MARVEL, 2013). 


\title{
2.5.4 Normas regulamentadoras brasileiras
}

As Normas Regulamentadoras (NR) são publicadas e editadas pelo Ministério do Trabalho e Emprego e estão baseadas em leis relativas à segurança e medicina do trabalho, contendo regras de caráter obrigatório com a finalidade de estabelecer requisitos técnicos e legais sobre os aspectos mínimos de Segurança e Saúde Ocupacional (SSO), seja diretamente, seja pela referência a normas técnicas, ou pela incorporação de todo ou apenas parte do conteúdo destas normas (ABIMAQ, 2016). Hoje são 36 normas regulamentadoras que tratam do assunto de segurança e medicina do trabalho (CÉSPEDES; ROCHA, 2017).

\footnotetext{
A portaria $\mathrm{n}^{\circ} 3.214$, de 8 de junho de 1978 , aprova as normas regulamentadoras - NR - do capítulo V, Título II, da Consolidação das Leis do Trabalho, relativas à segurança e medicina do Trabalho. Aprova a consolidação das leis do trabalho. As normas regulamentadoras - NR, relativas à segurança e medicina do trabalho, são de observância obrigatória pelas empresas privadas e públicas e pelos órgãos públicos da administração direta e indireta, bem como pelos órgãos dos Poderes Legislativo e Judiciário, que possuam empregados regidos pela Consolidação das Leis do Trabalho - CLT.

(CÉSPEDES; ROCHA, 2017, p. 179).
}

No Brasil, as normas regulamentadoras regidas pela CLT dispõem da norma regulamentadora $\mathrm{n}^{\circ} 12$ (NR-12), que trata dos aspectos de segurança relacionados a máquinas e equipamentos e é estruturada conforme indica o Quadro 10.

\begin{abstract}
Esta norma regulamentadora e seus anexos definem referências técnicas, princípios fundamentais e medidas de proteção para garantir a saúde e a integridade física dos trabalhadores e estabelecer requisitos mínimos para a prevenção de acidentes e doenças do trabalho nas fases de projeto de utilização de máquinas e equipamentos de todos os tipos, e ainda à sua fabricação, importação, comercialização, exposição e cessão a qualquer título, em todas as atividades econômicas, sem prejuízo da observância do disposto na demais Normas Regulamentadoras - NR aprovadas pela Portaria $\mathrm{n}^{\circ} 3.214$ de 8 de Junho de 1978, nas normas técnicas oficiais e , na ausência ou omissão destas, nas normas internacionais aplicáveis. (CÉSPEDES; ROCHA, 2017, p. 179).
\end{abstract}

A NR-12 se compõe de tópicos (distribuídos em 19 títulos com definições básicas e medidas de ordem geral para todas as máquinas) e anexos com disposições específicas ou excepcionalidades distribuídas em 12 títulos, conforme detalha o Quadro 11 (CÉSPEDES; ROCHA, 2017). 
Quadro 10: Estruturação da NR-12

\begin{tabular}{|l|l|l|}
\hline \multicolumn{2}{|c|}{ NR-12 - segurança no trabalho em máquinas e equipamentos } \\
\hline \multicolumn{1}{|c|}{ Sustentação } & \multicolumn{2}{|c|}{ Estrutura } \\
\hline Normas de conteúdo técnico: & Corpo: & Anexos: \\
NR-10, NR-11, NR13, NR-17, & Parte principal do corpo da norma & Anexos I, II, II, e IV contêm \\
NR-23, & com 19 tópicos & informações complementares para \\
NR-33 & & atendimento do corpo e demais \\
Normas ABNT (referências): & & anexos \\
NBR ISO 12100, NBR 14009, & & $\begin{array}{l}\text { Anexos V, VI, VII, VIII, IX, X, XI } \\
\text { NBR 13852, NBR 14153 }\end{array}$ \\
& & $\begin{array}{l}\text { determinados tipos } \\
\text { de máquinas }\end{array}$ \\
\hline
\end{tabular}

Fonte: Céspedes e Rocha, 2017

Quadro 11: Anexos da NR-12 em relação à especificação técnica ISO/TS 15066

\begin{tabular}{|c|c|c|c|c|c|}
\hline \multicolumn{2}{|c|}{$\begin{array}{l}\text { Anexos } \\
\end{array}$} & \multirow{2}{*}{ 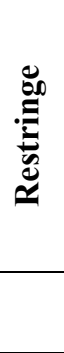 } & \multirow{2}{*}{ 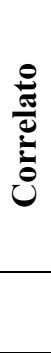 } & \multirow{2}{*}{ 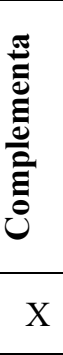 } & \multirow{2}{*}{ 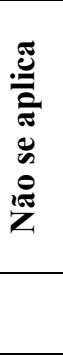 } \\
\hline Anexo I & $\begin{array}{l}\text { Distâncias de segurança e requisitos para o uso de detectores } \\
\text { de presença opto eletrônicos. (Quadros I, II, III e IV) }\end{array}$ & & & & \\
\hline Anexo II & Conteúdo programático da capacitação & & & $\mathrm{X}$ & \\
\hline Anexo III & Meios de acesso permanentes & & & & $\mathrm{X}$ \\
\hline Anexo IV & $\begin{array}{l}\text { Glossário (Portaria MTb no } 98 \text {, de } 08 \text { de fevereiro de } 2018 \text { / } \\
\text { portaria n. }{ }^{\circ} 326 \text {, de } 14 \text { de maio de } 2018 \text { - DOU de 15/05/2018 } \\
\text { - Seção 1) }\end{array}$ & & & $\mathrm{X}$ & \\
\hline Anexo V & Motosserras & & & & $\mathrm{X}$ \\
\hline Anexo VI & Máquinas para panificação e confeitaria & & & & $\mathrm{X}$ \\
\hline Anexo VII & Máquinas para açougue e mercearia & & & & $\mathrm{X}$ \\
\hline Anexo VIII & Prensas e similares & & & & $\mathrm{X}$ \\
\hline Anexo IX & $\begin{array}{l}\text { Injetora de Materiais Plásticos (Portaria MTb no } 98 \text {, de } 08 \text { de } \\
\text { fevereiro de } 2018 \text { / portaria n. } \text {. }^{\circ} 326 \text {, de } 14 \text { de maio de } 2018 \text { - } \\
\text { DOU de } 15 / 05 / 2018 \text { - Seção } 1 \text { ) }\end{array}$ & & & & $\mathrm{X}$ \\
\hline Anexo $\mathrm{X}$ & Máquinas para fabricação de calçados e afins & & & & $\mathrm{X}$ \\
\hline Anexo XI & Máquinas e implementos para uso agrícola e florestal & & & & $\mathrm{X}$ \\
\hline Anexo XII & $\begin{array}{l}\text { Equipamentos de guindar para elevação de pessoas e } \\
\text { realização de trabalhos em altura (Portaria MTb nº } 98 \text {, de } 08 \\
\text { de fevereiro de 2018) }\end{array}$ & & & & $\mathrm{X}$ \\
\hline
\end{tabular}

Fonte: Autor " adaptado de" Céspedes e Rocha, 2017 


\section{DESENVOLVIMENTO DA PESQUISA}

Este capítulo busca verificar como as normas internacionais e as normas brasileiras tratam e regulamentam o uso do cobot nas operações colaborativas, assim como discutir o que impede o uso do cobot em sua plenitude no Brasil. A Figura 8 apresenta o esquema gráfico da pesquisa para a identificação e análise dessas restrições.

Figura 8: Estrutura do projeto de pesquisa

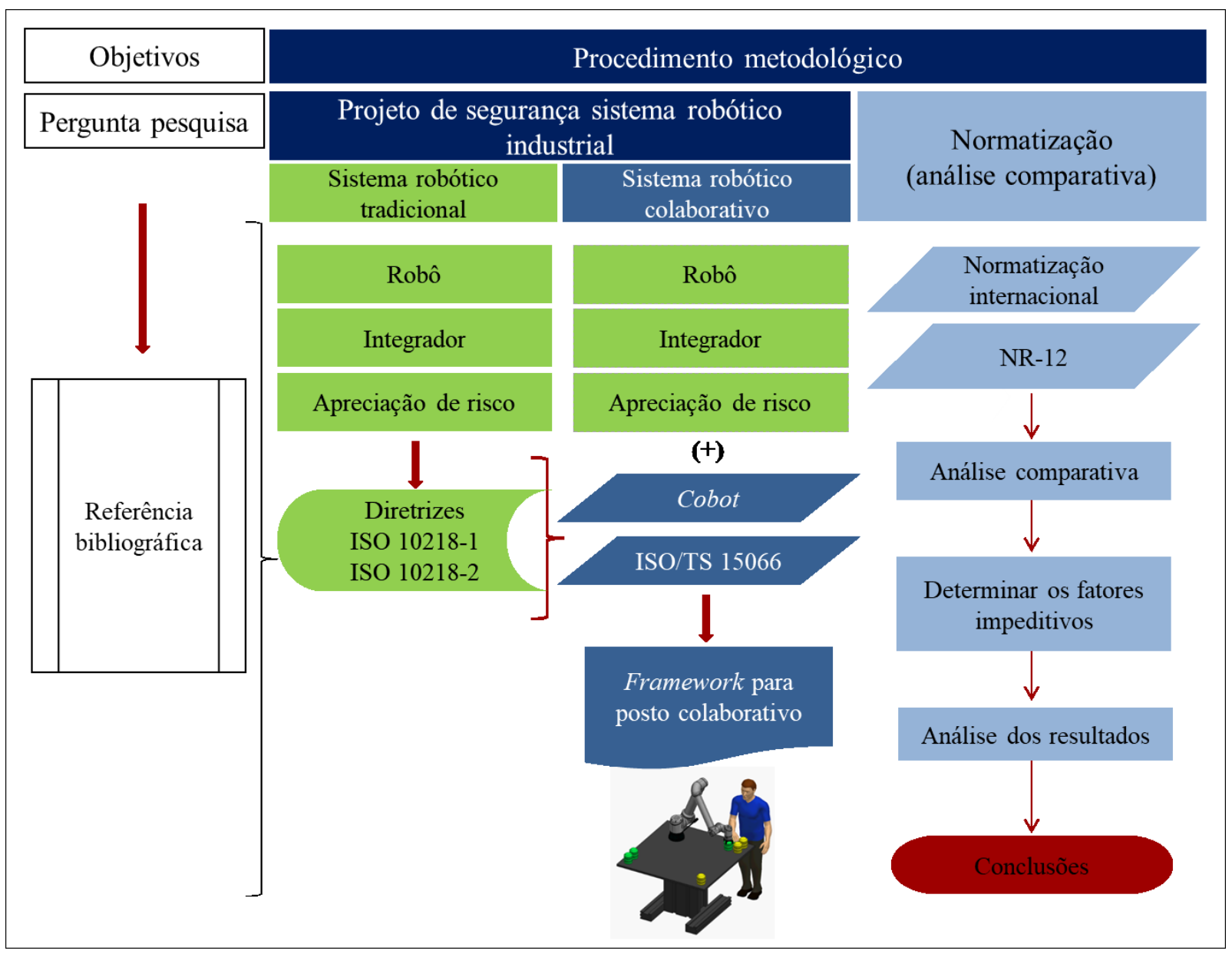

Fonte: Autor

\subsection{PROJETO DE SEGURANÇA DE UM SISTEMA ROBÓTICO INDUSTRIAL}

Para realizar a análise de normatização, esta pesquisa baseia-se no conceito de um sistema robótico colaborativo, configurado de acordo com a literatura específica. Ainda de acordo com a literatura, as características deste sistema robótico são premissas para observar 
os fatores normativos impeditivos na implantação de uma operação colaborativa no setor industrial brasileiro.

\subsubsection{Sistema robótico tradicional}

No sistema robótico industrial tradicional, os robôs industriais não colaborativos devem cumprir os requisitos de segurança descritos nas normas ISO 10218- parte 1 (MATTHIAS; REISINGER, 2016) e a norma EN ISO 12100 (GOPINATH; JOHANSEN, 2016), pois como não há necessidade de intervenção humana durante o processo de manufatura (pintar, soldar, rebarbar, etc.), existem regras rígidas para a segurança do ser humano e para interrupções de emergência do robô industrial. Tradicionalmente, em uma célula robotizada, a segurança do operador é mantida pela instalação de barreiras físicas, como grades de proteção e por meio de portões de acesso ao interior da célula, que são equipados com sistema de intertravamento para proporcionar a separação segura entre o robô e o operador.

Além das barreiras físicas, para evitar ferimentos nos operadores causados pelos movimentos dos robôs, são planejadas medidas de segurança extras para detecção de presença humana na área de trabalho dos mesmos, a fim de manter os operadores afastados enquanto os robôs estão em movimento (TSAROUCHI; SOTIRIS; CHRYSSOLOURIS, 2016). Essas medidas são asseguradas por meio de equipamentos de proteção projetados para detectar a presença de humanos na área de trabalho do robô, tais como barreiras de luz, sensores de presença, scanners, entre outros, e que devem seguir as diretrizes da norma ISO 10218-parte 2, que trata da integração dos sistemas robóticos.

Além dos sistemas físicos e equipamentos de segurança que compõem um sistema robótico, aplicam-se ao projeto do sistema robótico deste estudo os padrões e diretrizes de segurança internacionais que descrevem as velocidades permitidas, distância segura entre operador e robô, além de procedimentos para estabelecer a segurança necessária no posto de trabalho. De acordo com esses padrões e diretrizes de segurança, caso um operador necessite interagir com o robô para carregar ou descarregar peças dentro do espaço de trabalho do mesmo, o sistema de controle de segurança necessita identificar e confirmar que o robô se posicione em uma condição segura antes da interação com o operador, o que significa limitar com segurança seu movimento sob certas condições ou até mesmo desativar os movimentos de seus braços articulados, interrompendo de maneira imediata sua fonte de energia.

O desenvolvimento de diretrizes e requisitos na forma de padrões internacionais de segurança representa um esforço para garantir a segurança durante a interação humano-robô. A 
International Standard Organization (ISO) desenvolve documentos que especifiquem a melhor forma de manter a segurança durante a interação humano-robô industrial (PEDROCCHI et al., 2013). A síntese destas diretrizes necessárias para implantar um projeto de segurança em um sistema robótico considerada neste estudo de avaliação normativa é indicada pela Figura 9.

Figura 9: Diretrizes para o projeto de segurança do sistema robótico

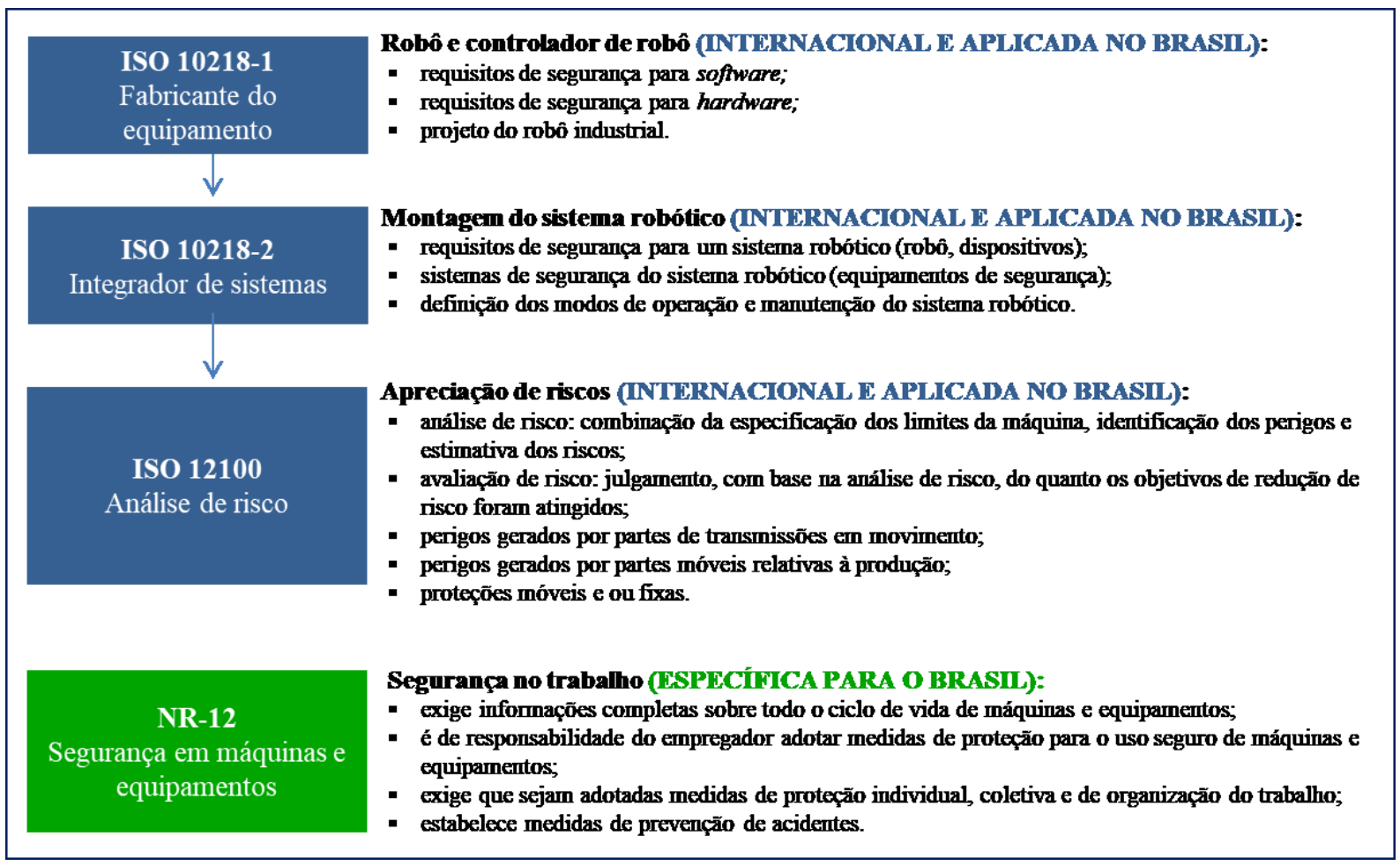

Fonte: Autor

No caso da segurança na operação colaborativa abordada nesta pesquisa, os padrões da norma ISO 10218 descrevem o termo robótica colaborativa como um sistema robótico operado automaticamente e que compartilha o mesmo espaço de trabalho com um humano. Contudo, um robô não é colaborativo por si só, sendo este equipamento parte da harmonia que se obtém quando se configura um sistema robótico colaborativo (BERTOLINI et al., 2016). Embora o os padrões de segurança internacionais desenvolvidos pela ISO representem um degrau para melhorar a segurança na interação humano-robô, ressalta-se que esses padrões são desenvolvidos especificamente para aplicações industriais.

A lacuna para incorporar a operação colaborativa é suprida internacionalmente pela especificação técnica ISO/TS 15066 (BDIWI; PFEIFER; STERZING, 2017), que será abordada a seguir. 


\subsubsection{Sistema robótico colaborativo}

A fim de comparar a normatização brasileira com a internacional para determinar os principais fatores limitadores do uso do robô colaborativo em uma operação colaborativa, este estudo considera complementar ao projeto de segurança de um sistema robótico que indica a Figura 9 (pré-requisito para a implantação de uma operação colaborativa), a adoção dos seguintes conceitos relacionados à configuração de um posto de trabalho colaborativo:

a) projeto do posto de trabalho: deve ser adequado para a concepção da segurança, baseando-se na normatização atual, de modo a obter a melhoria da segurança do operador dentro do espaço de trabalho compartilhado (CHERUBINI et al.; 2016);

b) abrangência do posto de trabalho: robô industrial, garra de manipulação, produto a ser manipulado e quaisquer equipamentos, dispositivos ou sensores que auxiliem o robô a executar sua tarefa (KHALID et al., 2016);

c) cobot: é um robô que pode ser usado em uma operação colaborativa. Os cobots com alta confiabilidade podem ser opções para executar tarefas repetitivas ou tarefas que não precisam de habilidades especiais (IBARGUREN et al., 2015). Para esta pesquisa, o cobot desempenha a função de manipular o produto;

d) colaboração humana: tem por finalidade, dentro do sistema robótico, coordenar o posto de trabalho, além de executar tarefas de identificar, agrupar e posicionar peças de maneira individual em dispositivos para a obtenção de partes e conjuntos completos bem como eliminar o contato físico com o cobot (GUIOCHET; MACHIN; WAESELYNCK, 2017);

e) tipos de operação colaborativa: seleção de um dos quatro métodos de colaboração padronizados pela ISO/TS 15066, mostrados no Quadro 9, no qual são recomendados para o desenvolvimento de soluções de sistemas robóticos colaborativos (HULL; MINARCIN, 2016).

Portanto, faz-se necessária a adoção dos conceitos de configuração descritos acima para se projetar a segurança de um posto de trabalho colaborativo. Para este estudo, os itens mostrados no diagrama conceitual proposto na Figura 10 funcionam como pré-requisitos para o comparativo entre a NR-12 e a ISO/TS 15066. 
Figura 10: Diagrama conceitual para implantar um posto de trabalho colaborativo

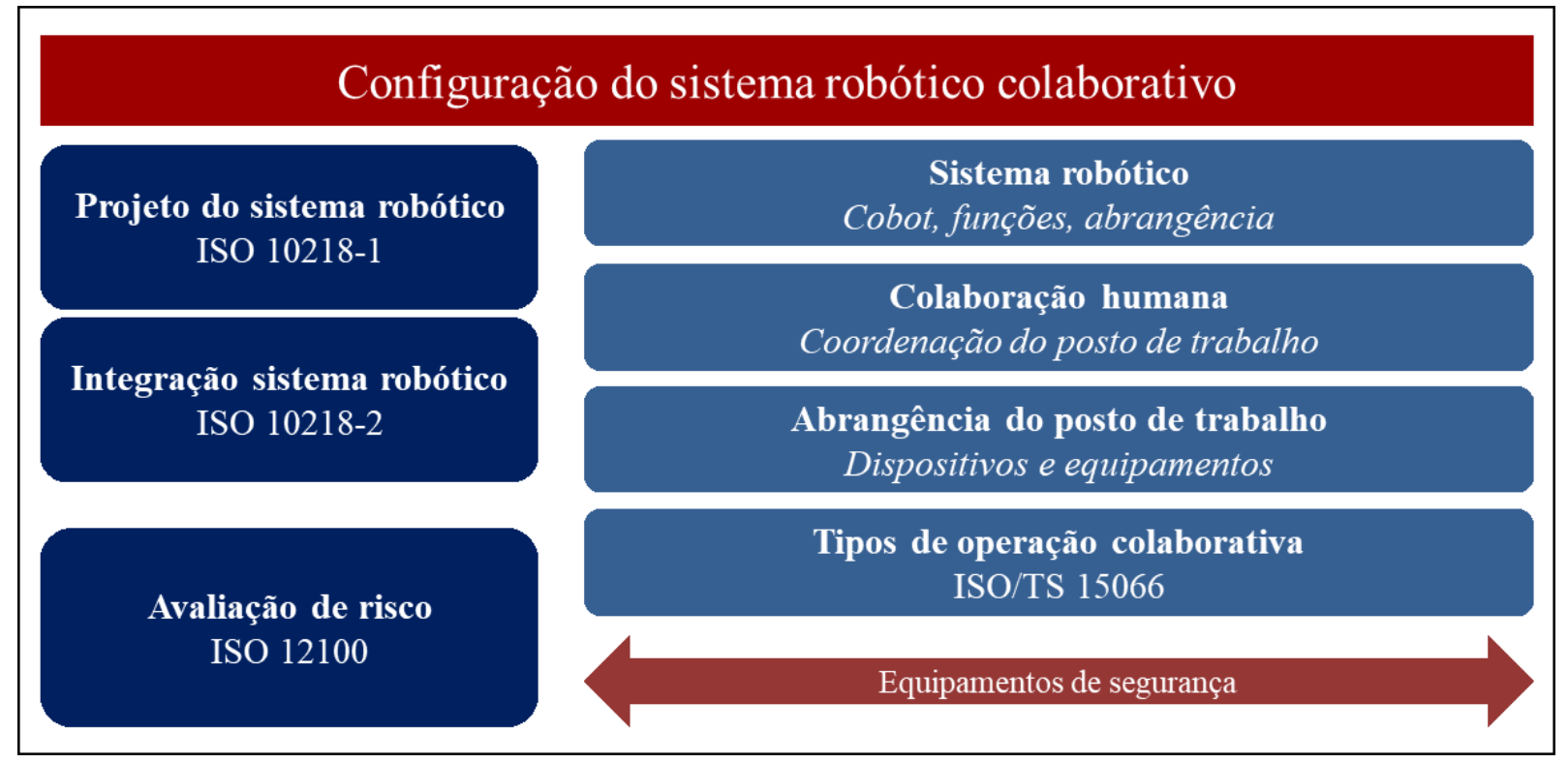

Fonte: Autor

\subsection{REQUISITOS PARA CONFIGURAR UMA OPERAÇÃO COLABORATIVA}

Após a adoção dos requisitos do projeto de segurança de um sistema robótico indicados na Figura 9, bem como dos requisitos para a configuração de um posto de trabalho colaborativo vistos no diagrama conceitual proposto para a implantação de um posto de trabalho colaborativo mostrado na Figura 10, este estudo propõe os requisitos para o projeto de um posto de trabalho de uma operação colaborativa. Esta configuração é necessária para avaliar as restrições da normatização brasileira para a implantação dos robôs colaborativos e se baseia em um layout conceitual dividido em quatro áreas operacionais, conforme mostra a Figura 11:

a) espaço de trabalho operacional: local projetado para a instalação completa do posto de trabalho, que inclui além do cobot e dos operadores, uma área para logística de peças e de movimentação de materiais. Inclui também os postos de trabalho que antecedem ou complementam o posto onde se realiza a operação colaborativa;

b) espaço de trabalho não colaborativo: área dedicada para os trabalhos realizados de maneira automática e sem a intervenção humana, onde aplicam-se as normativas de projeto de um sistema robótico tradicional. Nesta área de trabalho, o cobot pode se mover com a velocidade de um robô tradicional, que pode variar de acordo com a especificação de cada fabricante de cobot, conforme mostrado no Quadro 2;

c) espaço de trabalho colaborativo: área de trabalho dentro do espaço operacional onde o sistema do robô (incluindo o produto a ser manipulado) e um humano podem 
realizar tarefas simultaneamente durante a operação de produção, por meio de uma cooperação direta (SCHOLER; VETTE; RAINER, 2015). Nesta área de trabalho, o cobot pode se mover a uma velocidade que deverá ser determinada através da análise de apreciação de risco;

d) espaço de trabalho manual: destina-se às atividades exclusivamente realizadas pelos operadores, relacionadas aos registros de informações sobre os processos, à documentação do posto de trabalho, ao controle de estoque e de fluxo materiais, à gestão da qualidade, entre outros.

Figura 11: Layout conceitual de um posto de trabalho colaborativo

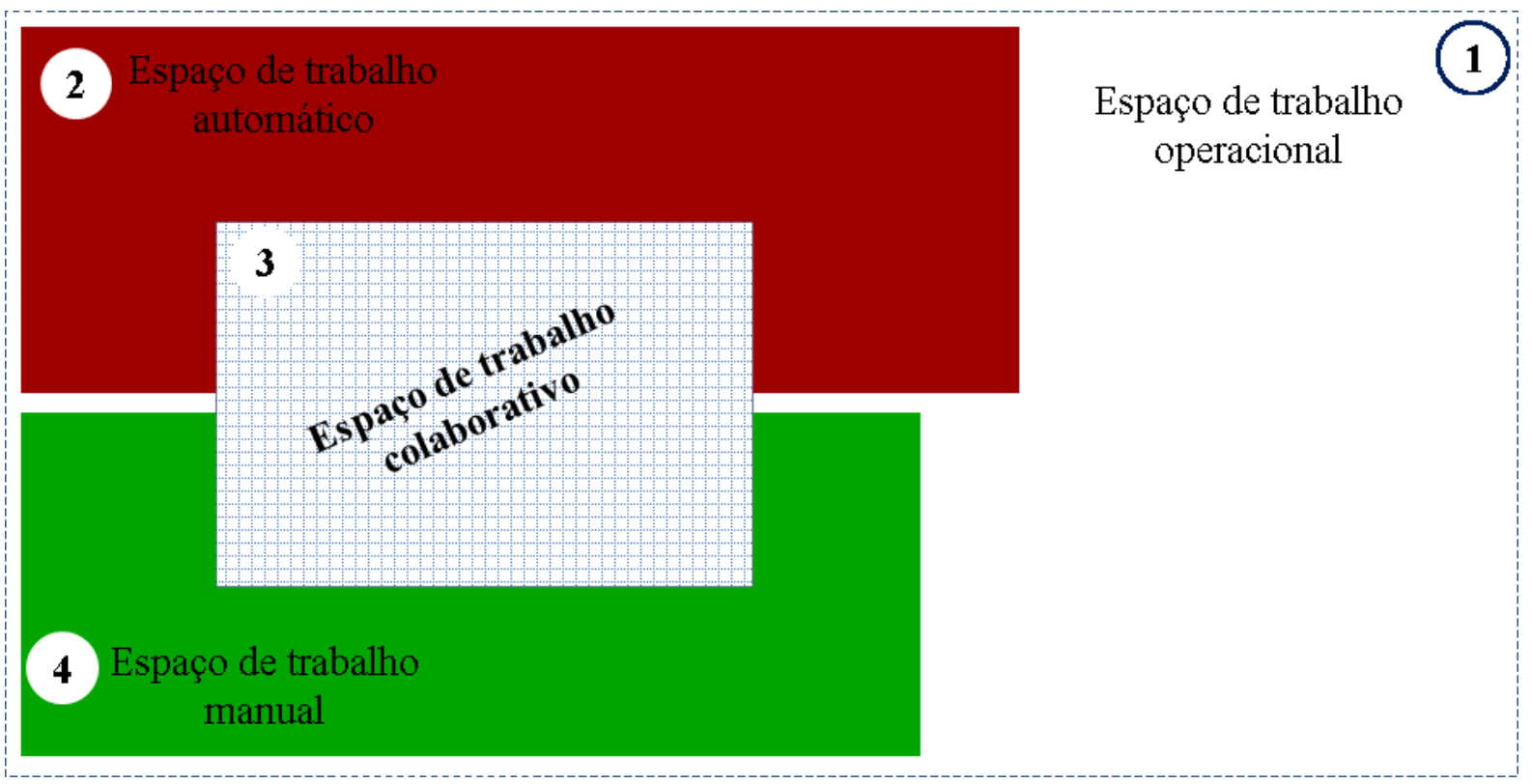

Fonte: Autor

Com base no layout conceitual mostrado na Figura 11, desenvolve-se um posto de trabalho colaborativo, conforme indica a Figura 12. Através do projeto deste posto de trabalho colaborativo, este estudo identifica as interfaces entre o operador e o cobot que ocorrem durante uma operação colaborativa. Desta maneira, podem-se estabelecer os momentos de colaboração, nos quais se devem aplicar as diretrizes da normatização internacional e da normatização brasileira. No caso deste estudo, trata-se da NR-12, que considera os espaços de trabalho colaborativo, durante o instante 1, e de trabalho automático, durante os instantes 2 e/ou 3 , 
Figura 12: Operação de trabalho colaborativa (layout esquemático)

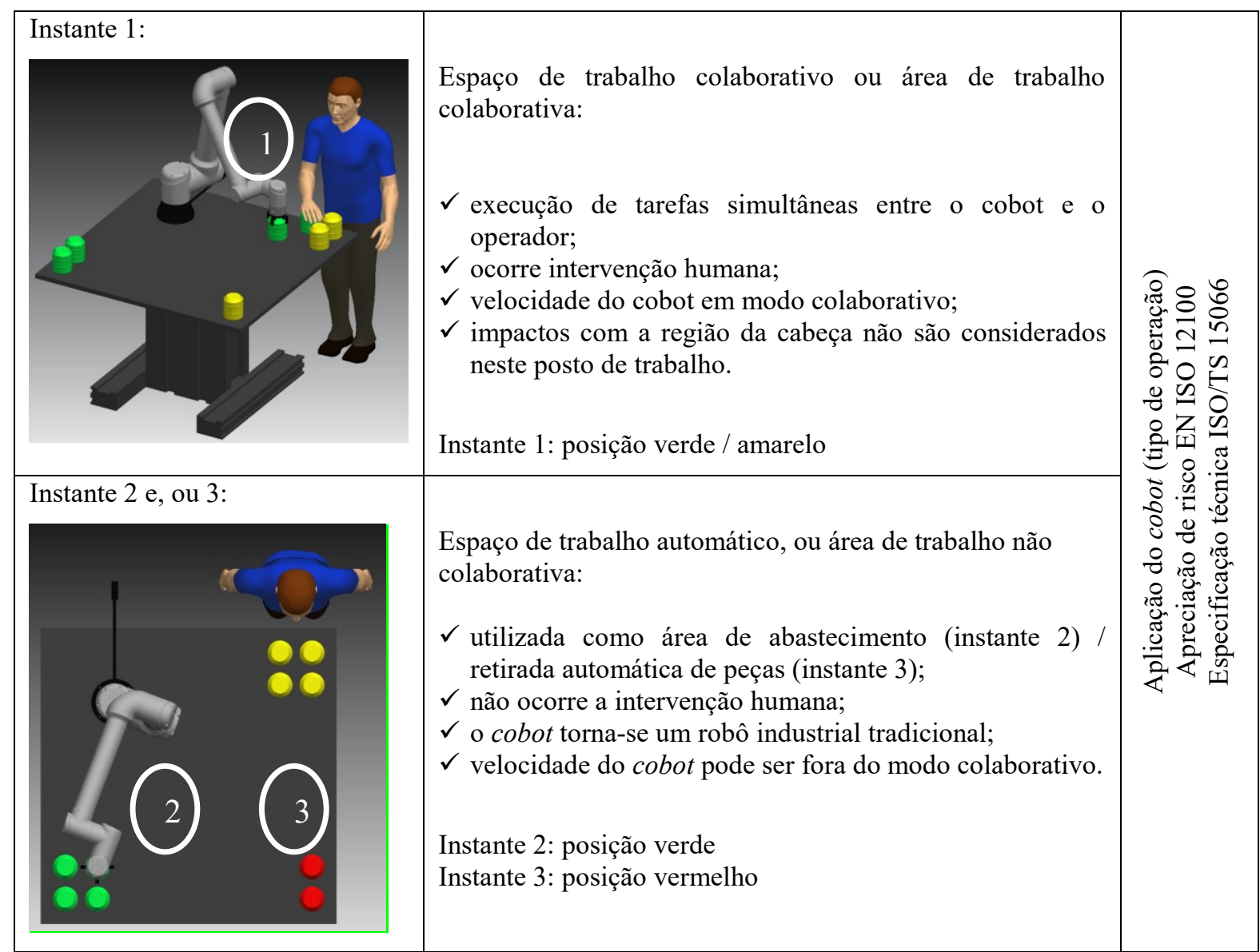

Fonte: Autor

A análise deste estudo considera ainda os seguintes aspectos de segurança, contemplados numa operação colaborativa:

a) aplicativo do robô: tarefas como manipulação de altas cargas, produtos ou ferramentas perfurantes, cortantes e/ou pontiagudas não são adequadas para a operação colaborativa (KHALID et al., 2016; BOGUE, 2016), mesmo quando o cobot executa a tarefa limitado por potência e força. Especificamente no caso de montagens com auxílio de materiais perfurantes ou cortantes, como no caso das operações de corte e dobra e na manipulação de produtos laminados, que podem oferecer risco de esmagamento ou corte no corpo do operador (GUIOCHET; MACHIN; WAESELYNCK, 2017). Por isso, a necessidade da elaboração de uma apreciação de risco para um sistema colaborativo;

b) dentro da estação de trabalho: a garra de manipulação, o produto a ser manipulado, a presença potencial de vários robôs e outros equipamentos são fatores que também devem ser levados em consideração ao se planejar uma instalação robótica segura, pois o cobot não funciona de maneira isolada; 
c) apreciação de risco da operação colaborativa: mesmo ao usar um robô projetado para uso colaborativo, deve-se avaliar e reduzir os riscos antes da implantação de uma operação colaborativa (CHINNIAH; AUCOURT; BOURBONNIÈRE, 2017). Portanto, é importante aplicar o padrão do projeto de segurança do sistema robótico colaborativo mostrado na Figura 10.

Finalmente, com base no Framework proposto para a implantação de um posto de trabalho colaborativo, mostrado na Figura 10, identificam-se que os padrões da normatização nacional e internacional preveem estratégias para os diferentes sistemas robóticos, conforme indica a Figura 13.

Figura 13: Síntese da normatização para sistemas robóticos

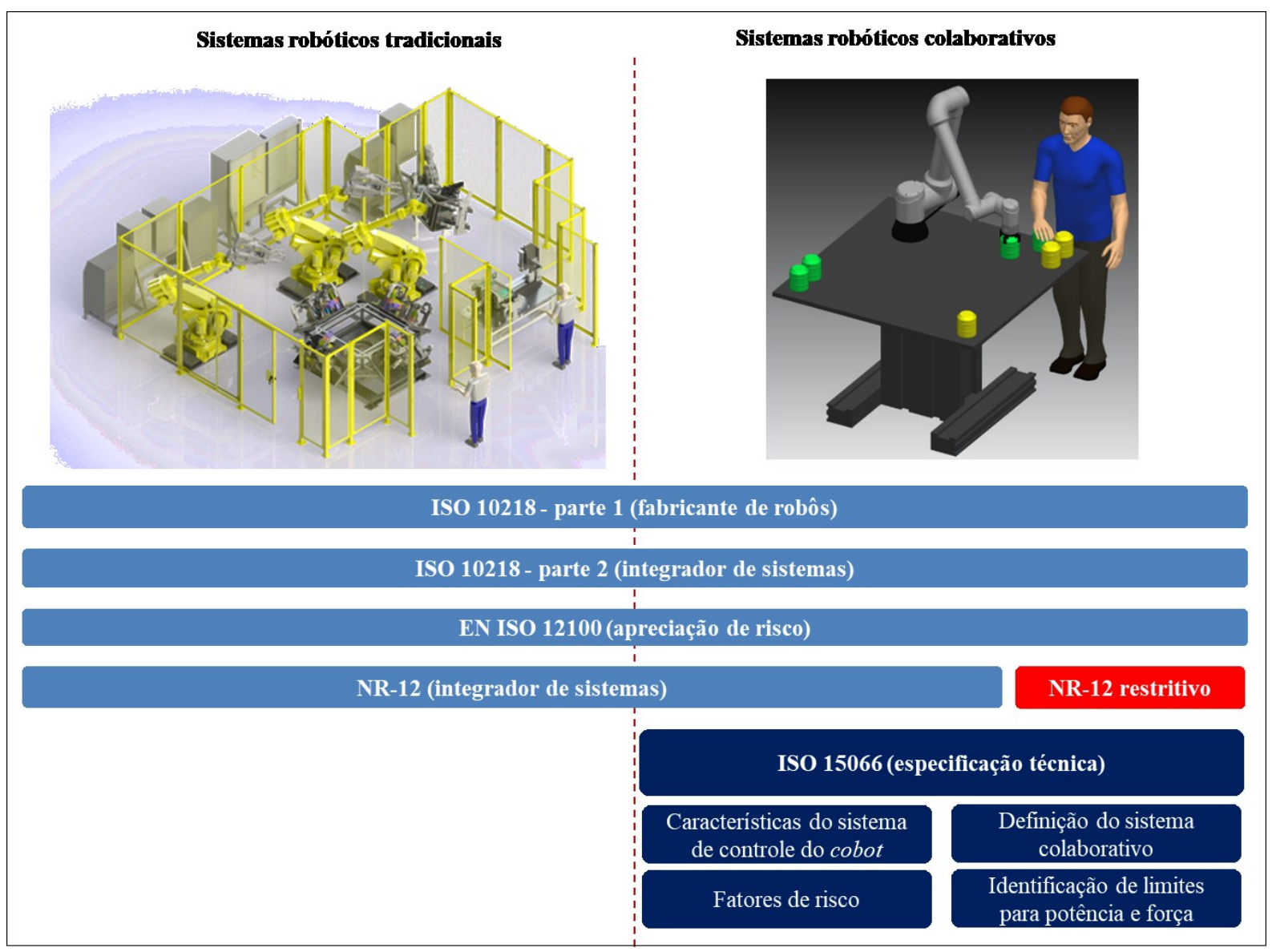

Fonte: Autor

Juntamente com os instantes 1, 2 e 3 mostrados na Figura 12, cada requisito da normatização deve ser selecionado e aplicado de acordo com o tipo de sistema robótico industrial que se pretende implementar na produção, incluindo no caso deste estudo as restrições da NR-12 mostrados no Quadro 12. No caso da operação colaborativa, a especificação técnica 
ISO/TS 15066 considera ainda informações para a orientação do projeto de sistemas de robôs colaborativos, incluindo aspectos que devem ser considerados na síntese de normatização de sistemas robóticos, mostrados na Figura 13, tais como:

a) definição de um sistema robótico colaborativo (IBARGUREN et al., 2015);

b) características do sistema de controle relacionado à segurança para a operação colaborativa (CERIANI et al., 2015);

c) identificação de fatores a serem levados em consideração no projeto de um sistema robótico colaborativo (DJURIC; URBANIC; RICKLI, 2016);

d) dados para ajudar a determinar os valores limites para limitar potência e força, a fim de evitar dor ou desconforto para o operador, devido à carga a ser manipulada (KHALID et al., 2016).

\subsection{ANÁLISE COMPARATIVA DA NORMATIZAÇÃO}

Com base na configuração do sistema robótico colaborativo e da síntese da normatização para sistemas robóticos elaborados para este trabalho e mostrados na Figura 12 e na Figura 13, analisam-se todos os dezenove tópicos mencionados na NR-12, consultados através do site do Ministério do Trabalho e Emprego. A análise é realizada em relação aos quatro tipos de operação colaborativa mencionados pela ISO/TS 15066 (GUIOCHET; MACHIN; WAESELYNCK, 2017; ANTONELLI; BRUNO, 2017), a fim de responder à pergunta da pesquisa, ou seja, identificar quais são os principais fatores da normatização que impedem o uso dos robôs colaborativos em sua plenitude nas operações industriais no Brasil.

Esta análise tem como base o construto interação (segurança, níveis de interação) levantado através da pesquisa bibliográfica mostrada na Tabela 1, sendo que o critério referenciado na literatura para esta análise é a de que o compartilhamento do espaço de trabalho não resulte em riscos para o operador e danos materiais para o cobot (MURASHOV; HEARL; HOWARD, 2016). Esta pesquisa incorpora também em sua análise os seguintes critérios que devem compor um posto de trabalho colaborativo:

a. análise antecipada da segurança do operador dentro do espaço de trabalho compartilhado através de uma apreciação de risco (CHERUBINI et al.; 2016);

b. certificação de que as tarefas planejadas para o cobot não necessitem de habilidades especiais (IBARGUREN et al., 2015); 
c. identificação, durante a avaliação de risco, dos tipos de tarefas, ferramentas e produtos a serem utilizados no espaço de trabalho colaborativo (KHALID et al., 2016).

Ainda em relação à etapa de análise dos tópicos impeditivos da NR-12, foram adotados três critérios para seleção e alocação dos itens, conforme a ISO/TS 15066:

a) impeditivo ao uso: não adere às determinações e ou especificações contidas na literatura;

b) compatível com a normatização internacional: adere e/ou acrescenta determinações e/ou especificações contidas na literatura;

c) não se relaciona: tópicos aplicados a outros tipos de processos, indústria e equipamentos, que não são aplicados ao posto de trabalho.

O fluxo de análise e seleção dos critérios adotados por este estudo para a identificação dos itens impeditivos na normatização é mostrado pela Figura 14.

Figura 14: Fluxo de análise para identificação dos fatores limitadores

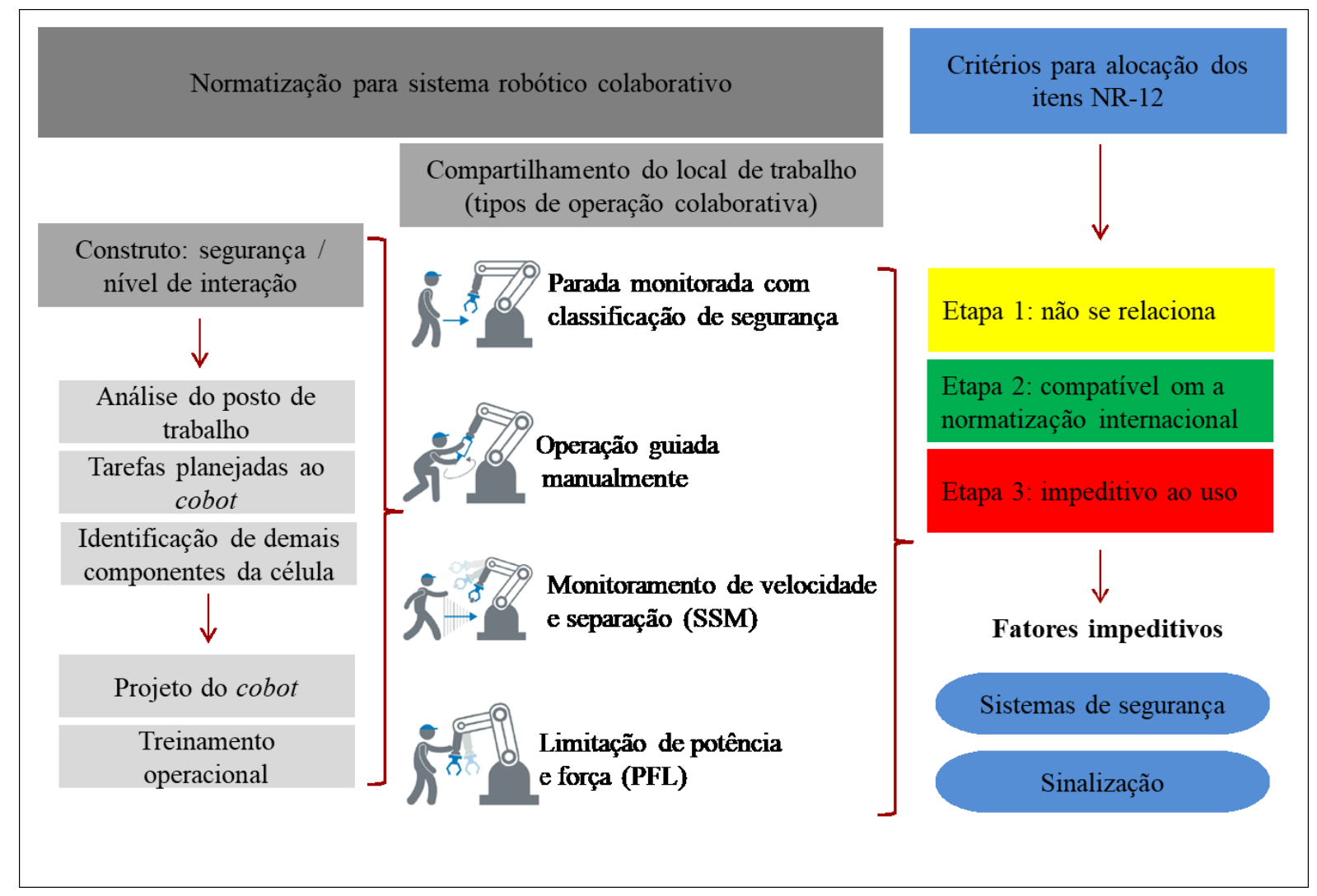

Fonte: Autor

O quadro 12 mostra de maneira ordenada, iniciando pelo item 12.1 - princípios gerais , os dezenove tópicos mencionados pela NR-12, aplicados a máquinas e equipamentos. Conduz- 
se a seleção para identificação dos fatores limitadores em relação à ISO/TS 15066 em três etapas. Na primeira etapa, trabalha-se na identificação dos itens que não se relacionam ao posto de trabalho colaborativo mostrado na Figura 12. Estes itens tratam de transportadores, componentes e requisitos de segurança específicos para certos tipos de atividades e indústrias.

$\mathrm{Na}$ segunda etapa, identificam-se os itens relacionados à operação colaborativa mostrada na Figura 12, e compatíveis com a normatização internacional. Trata-se basicamente de aspectos relacionados à organização e ergonomia no trabalho, planejamento, plano de métodos e processos do posto de trabalho, meios de acesso ao posto de trabalho (BARGUREN et al., 2015), da capacitação dos funcionários para o trabalho, do fornecimento de manuais de operação e manutenção do posto de trabalho, além de aspectos relacionados a layout, fluxo de materiais e equipamentos de segurança extras (SHACKLEFORD et al., 2016).

Finalmente, na terceira etapa, analisam-se os itens impeditivos ao uso na operação colaborativa mostrada na Figura 12. A identificação dos itens impeditivos tem como base os quatro tipos de operação colaborativa da ISO/TS 15066 (VYSOCKY; NOVAK, 2016), na elaboração da apreciação de riscos para a operação colaborativa (CHINNIAH; AUCOURT; BOURBONNIÈRE, 2017), na identificação das limitações da colaboração devidas às preocupações com segurança ou lesões que o operador pode sofrer (CHARALAMBOUS; FLETCHER; WEBB, 2015), na combinação das habilidades dos operadores e dos cobots de maneira harmoniosa dentro do espaço de trabalho colaborativo (Tsarouchi; Sotiris; Chryssolouris, 2016; ZANCHETTIN et al., 2016).

Além da certificação de que as tarefas planejadas para o cobot não necessitem das habilidades especiais discutidas por Ibarguren et al. (2015), esta pesquisa considera também que o cobot deve atender a certos requisitos para a análise de normatização. Um dos requisitos considerados neste estudo é o de que o cobot deve ter seu projeto compacto e leve, ser de fácil manuseio para movimentação, para oferecer interação com o ambiente de trabalho e os humanos (CHARALAMBOUS; FLETCHER; WEBB, 2015). Por isso, os cobots que interagem com humanos em uma operação colaborativa exigem recursos de detecção e controle para permitir uma interação habilidosa e compatível. Desta maneira, o cobot precisa de estratégias de controle concebidas em seu projeto, que permitam detectar colisões inesperadas com o ambiente e com os humanos, e deve conseguir, como resultado, ter capacidade de reagir a uma potencial situação de colisão de maneira segura durante uma operação colaborativa (KHALID et al., 2016). Sensores de torque alocados em cada articulação do cobot apresentam-se como uma solução para o controle da força em um momento de risco durante a operação colaborativa. 
Quadro 12: Tópicos da NR-12 em relação à especificação técnica ISO/TS 15066

\begin{tabular}{|c|c|c|c|c|}
\hline \multicolumn{2}{|l|}{ Tópicos da NR-12 } & \multicolumn{3}{|c|}{ Em relação à especificação técnica ISO/TS 15066} \\
\hline & & Etapa 3: restritivo & Etapa 2: compatível & $\begin{array}{l}\text { Etapa 1: não se } \\
\text { relaciona }\end{array}$ \\
\hline Princípios Gerais & $\begin{array}{l}12.1 \text { ao } \\
12.5\end{array}$ & & $\begin{array}{l}12.1 ; 12.3 ; 12.4 ; \\
12.5 \text { (realizar análise } \\
\text { de risco); }\end{array}$ & 12.2 \\
\hline $\begin{array}{l}\text { Arranjos Físicos e } \\
\text { Instalações }\end{array}$ & $\begin{array}{l}12.6 \text { ao } \\
12.13\end{array}$ & & $\begin{array}{l}12.6 ; 12.6 .1 ; 12.6 .2 ; \\
12.7 ; 12.8 ; 12.9 ; \\
12.10 ; 12.13\end{array}$ & $\begin{array}{l}\text { 12.11;12.12; 12.13; } \\
12.13 .1\end{array}$ \\
\hline $\begin{array}{l}\text { Instalações e dispositivos } \\
\text { Elétricos }\end{array}$ & $\begin{array}{l}12.14 \text { ao } \\
12.23\end{array}$ & & $\begin{array}{l}12.14 ; ; 12.15 ; 12.16 ; \\
12.17 ; 12.18 ; \\
12.19 ; 12.21\end{array}$ & $12.20 ; 12.22 ; 12.23$ \\
\hline $\begin{array}{l}\text { Dispositivos de Partida, } \\
\text { Acionamento e Parada }\end{array}$ & $\begin{array}{l}12.24 \text { ao } \\
12.37 .1\end{array}$ & & $\begin{array}{l}12.24 ; 12.25 ; 12.31 ; 12 \\
.32 ; 12.34 ; \\
12.36 ; 12.37\end{array}$ & $\begin{array}{l}12.26 ; 12.27 ; \\
12.28 ; 12.29 ; 12.30 ; \\
12.30 .2 ; 12.33 ; 12.35\end{array}$ \\
\hline Sistemas de Segurança & $\begin{array}{l}12.38 \text { ao } \\
12.55 .1\end{array}$ & $\begin{array}{l}12.38 ; 12.41 ; \\
12.43 ; 12.44 ; 12.47 ; \\
12.49 ; 12.51\end{array}$ & $\begin{array}{l}12.39 ; 12.42 ; 12.54 ; \\
12.55\end{array}$ & $\begin{array}{l}12.45 ; 12.46 ; 12.48 ; 1 \\
2.50 ; 12.52 ; 12.53\end{array}$ \\
\hline $\begin{array}{l}\text { Dispositivos de Parada de } \\
\text { Emergência }\end{array}$ & $\begin{array}{l}12.56 \text { ao } \\
12.63 .1\end{array}$ & & 12.56 ao 12.63 .1 & \\
\hline $\begin{array}{l}\text { Meios de Acesso } \\
\text { Permanentes }\end{array}$ & $\begin{array}{l}12.64 \text { ao } \\
12.76 .1 \\
\end{array}$ & & & 12.64 ao 12.76 .1 \\
\hline $\begin{array}{l}\text { Componentes } \\
\text { Pressurizados }\end{array}$ & $\begin{array}{l}12.77 \text { ao } \\
12.84 .1 \\
\end{array}$ & & & 12.77 ao 12.84 .1 \\
\hline $\begin{array}{l}\text { Transportadores de } \\
\text { Materiais }\end{array}$ & $\begin{array}{l}12.85 \text { ao } \\
12.93 .1\end{array}$ & & & $\begin{array}{l}12.85 \text { ao } 12.93 .1 ; \\
12.93 .2 .1 ; 12.93 .3\end{array}$ \\
\hline Aspectos Ergonômicos & $\begin{array}{l}12.94 \text { ao } \\
12.105\end{array}$ & & $\begin{array}{l}12.99 ; 12.94 ; \\
12.95 ; 12.96 ; 12.98 ; 12 \\
.100 ; 12.101 ; 12.102 ; \\
12.103 ; 12.104 \\
\end{array}$ & $12.97 ; 12.105$ \\
\hline Riscos Adicionais & $\begin{array}{l}12.106 \text { ao } \\
12.110\end{array}$ & & 12.110 & $\begin{array}{l}\text { 12.106;12.107;12.10 } \\
8 ; 12.109 ;\end{array}$ \\
\hline $\begin{array}{l}\text { Manutenção, Inspeção, } \\
\text { Preparação, Ajustes e } \\
\text { Reparos }\end{array}$ & $\begin{array}{l}12.111 \text { ao } \\
12.115\end{array}$ & & 12.111 ao 12.115 & \\
\hline Sinalização & $\begin{array}{l}12.116 \text { ao } \\
12.124 .1\end{array}$ & $\begin{array}{l}12.116 ; 12.117 \\
12.118\end{array}$ & $\begin{array}{l}12.119 ; 12.120 ; \\
12.121 ; 12.122 ; \\
12.123 ; 12.124\end{array}$ & \\
\hline Manuais & $\begin{array}{l}12.125 \text { ao } \\
12.129 .1\end{array}$ & & 12.125 ao 12.129 .1 & \\
\hline $\begin{array}{l}\text { Procedimentos de trabalho } \\
\text { e segurança }\end{array}$ & $\begin{array}{l}12.130 \text { ao } \\
12.132 .2\end{array}$ & & 12.130 ao 12.132 .2 & \\
\hline $\begin{array}{l}\text { Projeto, fabricação, } \\
\text { importação, venda, } \\
\text { locação, leilão, cessão a } \\
\text { qualquer título e exposição }\end{array}$ & $\begin{array}{l}12.133 \text { ao } \\
12.134\end{array}$ & & & \\
\hline Capacitação & $\begin{array}{l}12.135 \text { ao } \\
12.147 .2\end{array}$ & & 12.135 ao 12.147 .2 & \\
\hline $\begin{array}{l}\text { Outros requisitos } \\
\text { específicos de segurança }\end{array}$ & $\begin{array}{l}12.148 \text { ao } \\
12.152 .1\end{array}$ & & $\begin{array}{l}12.148 ; 12.149 \\
12.150\end{array}$ & $12.151 ; 12.152$ \\
\hline Dispositivos finais & $\begin{array}{l}12.153 \text { ao } \\
12.156\end{array}$ & & $12.153 ; 12.154$ & $12.155 ; 12.156$ \\
\hline
\end{tabular}

Fonte: Autor " adaptado de" Ministério do Trabalho e Emprego, 2018 
Além da especificação do cobot, outro requisito considerado nesta pesquisa para a operação colaborativa é o treinamento para abordar a indisciplina, pois um operador determinado a contornar dispositivos e sistemas destinados a garantir a segurança sempre será um problema., É importante que as pessoas compreendam que simplesmente retirar a grade de proteção ao redor da célula não torna o sistema robótico industrial um sistema colaborativo. Por isso, faz-se necessário um treinamento adequado para seus usuários para garantir a segurança durante uma operação colaborativa. Após a menção dos requisitos considerados na análise e da identificação dos itens restritivos com base na distribuição dos tópicos da NR-12 mostrados no Quadro 12, os tópicos principais que contêm restrições que não têm aderência junto à literatura específica e à ISO/TS 15066 foram agrupados em:

a) sistemas de segurança;

b) sinalização.

Ainda com base nos dados mostrados no Quadro 12, a análise identificou que os itens limitadores, relacionados ao tópico sistemas de segurança, abordam os aspectos sobre proteções físicas, proteções móveis e equipamentos de segurança, enquanto os itens limitadores, relacionados ao tópico sinalização, abordam aspectos da sinalização de segurança do equipamento para advertir e alertar os operadores sobre perigos. Os detalhes dos itens limitadores são mostrados no Quadro 13, e estão de acordo com o Ministério do Trabalho e Emprego.

Quadro 13: Itens limitadores da NR-12

(continua)

\begin{tabular}{|l|l|}
\hline Item & Descrição / síntese \\
\hline 12.38 & $\begin{array}{l}\text { As zonas de perigo das máquinas e equipamentos devem possuir sistemas de segurança, caracterizados } \\
\text { por proteções fixas, proteções móveis e dispositivos de segurança interligados, que garantam proteção } \\
\text { à saúde e à integridade física dos trabalhadores. }\end{array}$ \\
\hline 12.41 & $\begin{array}{l}\text { Considera-se proteção o elemento especificamente utilizado para prover segurança por meio de } \\
\text { barreira física, podendo ser: } \\
\text { a) proteção fixa, que deve ser mantida em sua posição de maneira permanente ou por meio de } \\
\text { elementos de fixação que só permitam sua remoção ou abertura com o uso de ferramentas; } \\
\text { b) proteção móvel, que pode ser aberta sem o uso de ferramentas, geralmente ligada por elementos } \\
\text { mecânicos à estrutura da máquina ou a um elemento fixo próximo. }\end{array}$ \\
\hline 12.43 & $\begin{array}{l}\text { Os componentes relacionados aos sistemas de segurança devem garantir a manutenção do estado } \\
\text { seguro da máquina ou equipamento quando ocorrerem flutuações no nível de energia além dos limites } \\
\text { considerados no projeto, incluindo o corte e restabelecimento do fornecimento de energia. }\end{array}$ \\
\hline 12.44 & $\begin{array}{l}\text { Proteção deve ser móvel quando o acesso a uma zona de perigo for requerido, observando-se que: } \\
\text { a) a proteção deve ser associada a um dispositivo de intertravamento quando sua abertura não } \\
\text { possibilitar o acesso à zona de perigo antes da eliminação do risco; e } \\
\text { b) a proteção deve ser associada a um dispositivo de intertravamento com bloqueio quando sua } \\
\text { abertura possibilitar o acesso à zona de perigo antes da eliminação do risco. }\end{array}$ \\
\hline 12.47 & $\begin{array}{l}\text { As transmissões de força e os componentes móveis a elas interligados devem possuir proteções fixas, } \\
\text { ou móveis com dispositivos de intertravamento, que impeçam o acesso por todos os lados. }\end{array}$ \\
\hline
\end{tabular}


(conclusão)

\begin{tabular}{|l|l|}
\hline 12.49 & $\begin{array}{l}\text { As proteções devem ser projetadas e construídas de modo a atender aos seguintes requisitos: } \\
\text { a) cumprir suas funções apropriadamente durante a vida útil da máquina ou possibilitar a reposição de } \\
\text { partes deterioradas ou danificadas; } \\
\text { b) ser constituídas de materiais resistentes e adequados à contenção de projeção de peças, materiais; } \\
\text { c) fixação e resistência mecânica compatíveis com os esforços requeridos; } \\
\text { d) não criar pontos de esmagamento ou agarramento com partes da máquina ou com outras proteções; } \\
\text { e) não possuir extremidades e arestas cortantes ou outras saliências perigosas; }\end{array}$ \\
\hline 12.51 & $\begin{array}{l}\text { A localização dos atuadores de rearme ("reset") manual deve permitir uma visão completa da zona } \\
\text { protegida pelo sistema. (Inserido pela Portaria MTb n. }{ }^{\circ} \text { 98, de 08 e fevereiro de 2018) }\end{array}$ \\
\hline 12.116 & $\begin{array}{l}\text { As máquinalização e equipamentos devem possuir sinalização de segurança para advertir os trabalhadores } \\
\text { sobre os riscos a que estão expostos, as instruções de operação e manutenção e outras informações } \\
\text { necessárias para garantir a integridade física e a saúde dos trabalhadores. }\end{array}$ \\
\hline 12.117 & $\begin{array}{l}\text { A sinalização de segurança deve: } \\
\text { a) ficar destacada na máquina ou equipamento; } \\
\text { b) ficar em localização claramente visível; e } \\
\text { c) ser de fácil compreensão. }\end{array}$ \\
\hline 12.118 & $\begin{array}{l}\text { Os símbolos, inscrições e sinais luminosos e sonoros devem seguir os padrões estabelecidos pelas } \\
\text { normas técnicas nacionais vigentes e, na falta dessas, pelas normas técnicas internacionais. }\end{array}$ \\
\hline
\end{tabular}

Fonte: Autor " adaptado de" Ministério do Trabalho e Emprego, 2018

\subsection{ATUALIZAÇÕES DA NR-12}

Este estudo contempla as seguintes atualizações impostas à NR-12 até o período de 14 de maio de 2018, conforme dados do Ministério do Trabalho e Emprego.

Portaria $n^{\circ} 98$ de fevereiro: destaca a inclusão no anexo IV (glossário) de definições como: apreciação de risco, análise de risco, avaliação de risco, circuito elétrico de comando, contatos mecanicamente ligados, contatos espelho, controles, entre outras. Além disso, apresenta alterações em conceitos já presentes no Anexo IV. Houve também a inclusão do item 7.3 no Anexo XII - Equipamentos de Guindar para Elevação de Pessoas e Realização de Trabalho em Altura da NR 12.

Portaria nº 252, 10 de abril de 2018: apresenta nova redação do Anexo X - Máquinas para Fabricação de Calçados e Afins da NR-12.

Portaria n ${ }^{0}$ 326, de 14 de maio de 2018 (DOU de 15/05/2018 - Seção 1): define a regra de proteção para circulação de pessoas sob transportadores contínuos de materiais e inclui itens específicos de equipamento teleférico envolvendo transporte de cargas suspensas. Adequa a redação de termos técnicos para as regras relativas à utilização de dispositivos de acionamento bimanual. Inclui também novos conceitos técnicos no anexo IV - Glossário, para facilitar o entendimento da Norma e padronizar as definições com as normas técnicas internacionais. Não é aplicada a robótica colaborativa. 


\section{ANÁLISE DOS RESULTADOS}

Este capítulo apresenta a análise dos principais resultados coletados sobre os fatores limitadores da normatização brasileira sobre a segurança da colaboração humano-robô. Esta pesquisa analisou as diferenças entre as diretrizes internacionais sobre segurança na operação colaborativa e os requisitos da NR-12, com a perspectiva de novos passos para utilizar o cobot dentro de requisitos normativos, pois os padrões da indústria e dos robôs industriais evoluem para acomodar níveis maiores de segurança no local de trabalho e devem ser acompanhados pela normatização nacional e internacional para não resultar em atrasos na utilização dos benefícios que as novas tecnologias podem propor às empresas (GROU et al.,2018).

Este estudo mostra que a aplicação da NR-12 demanda uma interpretação sobre as condições de segurança dos operadores, que devem ser associadas aos recursos de sensoriamento disponíveis nas novas tecnologias, bem como ao atendimento da normatização internacional, desenvolvida para a aplicação do cobot em uma operação colaborativa.

Embora esta pesquisa não tenha o propósito de alterar a normatização vigente, algumas das características das divergências entre a normatização brasileira e a internacional identificadas nesta pesquisa podem ajudar a compreender as restrições contidas na NR-12 em relação à literatura, conforme mostra o Quadro 12, especialmente aos sistemas de segurança e equipamentos de sinalização identificados por este estudo. Com base na proposição elaborada para o desenvolvimento desta pesquisa, apresentada na Tabela 1 (interação - segurança, níveis de interação), a análise da normatização apresenta os seguintes resultados em relação às restrições normativas e de segurança na operação colaborativa:

\subsection{RESTRIÇÕES NORMATIVAS}

Este não foi o maior desafio desta pesquisa, pois a literatura específica aponta para uma efetivação da operação colaborativa no mundo, enquanto que a normatização brasileira restringe o processo de operação colaborativa, ao não considerar os aspectos tecnológicos embarcados nos cobots descritos na literatura como recursos para auxiliar na segurança humana (HARPER; VIRK, 2010), principalmente as barreiras físicas. De fato, um dos resultados mais importantes deste estudo foi poder evidenciar as restrições contidas na NR-12 em relação aos tipos de operações colaborativas contidas na ISO/TS 15066 e indicar a necessidade de atualização da normatização brasileira para acomodar os tipos de operação colaborativa 
aplicados mundialmente. A nota técnica 31/2018 é um passo para amenizar esta situação e interagir com a normatização internacional.

A primeira análise trata dos sistemas de segurança para zonas de perigo, que devem ser adicionados ao equipamento, em especial a necessidade de implantação de proteções fixas ou móveis no posto de trabalho. De acordo com a literatura especializada, este item se faz necessário quando do uso dos robôs industriais tradicionais, pois os mesmos ainda não são autônomos para uma aplicação em uma operação colaborativa (TAROUCHI; SOTIRIS; CHRYSSOLOURIS, 2016; BOGUE, 2016).

Para o uso em uma operação colaborativa, este item restringe, mas de acordo com a literatura, os cobots projetados para trabalhos colaborativos são caracterizados por proporcionar uma cooperação síncrona com os humanos (GROOVER, 2017), e desta maneira, uma característica da operação colaborativa é o desenvolvimento do layout do posto de trabalho, que deve ser flexível para alterações (MÜLLER; VETTE; SCHOLER, 2016) e que não considera necessário o uso de proteções fixas ou proteções móveis recomendado pela NR-12, conforme mostra a Figura 12. De fato, os cobots cumprem suas funções na operação colaborativa como unidades produtivas independentes, com segurança, ao lado dos humanos, e sem necessidade de proteções físicas (IBARGUREN et al., 2015).

Outro aspecto da análise comparativa refere-se de maneira particular à utilização de uma proteção móvel em um sistema robótico. Nesta condição, segundo a NR-12, este tipo de proteção deve ser associado a um dispositivo de intertravamento que, após a sua abertura, não possibilite o acesso à zona de perigo antes da eliminação do risco, ou seja, antes da parada total dos movimentos do robô. Para o uso do robô tradicional, segundo a NR-12, faz-se necessário este dispositivo de intertravamento na proteção, devido à separação dos humanos por razões de segurança, pois os mesmos trabalham de maneira isolada (SHACKLEFORD et al., 2016; BERTOLINI et al.; 2016) e podem causar ferimentos graves nos trabalhadores ao entrar em contato com eles durante o processo de trabalho (GASKILL; WENT, 1996).

Contudo, no âmbito da colaboração humano-robô se deve alcançar níveis de segurança elevados, quando ocorre o contato físico entre o operador e o cobot (NAVARRO et al.; 2016. Portanto, para uma aplicação colaborativa, concebe-se o cobot com a função de parada monitorada de segurança, que causa uma parada protetora antes que o operador entre no espaço de trabalho colaborativo (HULL; MINARCIN, 2016). Desta maneira, não se habilita o cobot a entrar no espaço de trabalho colaborativo, enquanto o operador estiver dentro dessa área (BDIWI; PFEIFER; STERZING, 2017). Esses são aspectos dos tipos de operação colaborativa não considerados na NR-12. 
A análise mostra também a recomendação da NR-12 para a aplicação de sinalização de segurança nos equipamentos para advertir os trabalhadores e terceiros sobre potenciais riscos no posto de trabalho robotizado. Esta sinalização é requerida quando da utilização de proteções móveis para o operador adentrar uma célula robotizada, a fim de realizar algum tipo de manutenção ou reparo. Neste caso, faz-se necessária a sinalização sobre o posicionamento correto do botão de emergência, indicando a parada total do robô antes do operador adentrar a célula através da proteção móvel. Indicação de perigos de ferimento, quando do contato entre o operador e o robô industrial tradicional também são dispostos no posto de trabalho.

No caso da operação colaborativa, devem ser aplicadas metodologias de apreciação de risco (GOPINATH; JOHANSEN, 2016), além de requisitos de segurança adequados ao robô industrial para trabalhar com humanos em um mesmo espaço de trabalho. A especificação técnica ISO/TS 15066 deve ser aplicada em complemento à NR-12, visando reduzir restrições de contato na interação humano-robô (BDIWI; PFEIFER; STERZING, 2017).

Outra evidência é a elaboração da nota técnica n 31/2018/CGNOR/DSST/SIT/MTb, que esclarece quanto às novas tecnologias de robôs, denominados robôs colaborativos e robôs tradicionais em aplicações colaborativas, suas atribuições em relação aos requisitos de segurança necessários ao trabalho seguro com esses tipos de robôs. De acordo com esta nota técnica, a aplicação deste tipo de robô não descumpre mais a NR-12. Porém, é preciso que seja elaborada uma apreciação de risco ampla e em conformidade com a normatização internacional. Este estudo propõe que a referida nota técnica caracterize o robô colaborativo para a utilização nas operações colaborativas, alertando para a necessidade da adoção de tecnologias já concebidas no projeto do mesmo, a fim de limitar a potência dinâmica, força estática e velocidade, em conformidade com o item 5.4 da ISO 10218 - parte 1 (BDIWI; PFEIFER; STERZING, 2017).

Assim, pode-se evitar que através de uma interpretação errada, seja dimensionado um robô convencional para uma operação caracterizada como colaborativa, uma vez que a referida nota também faz menção ao uso dos robôs tradicionais em operação colaborativa, sendo que os mesmos não são colaborativos e seguros para a operação colaborativa em sua concepção (KOOTBALLY, 2016).

Com o intuito de resumir o comparativo, o Quadro 14 mostra a síntese dos resultados obtidos neste estudo. Em suma, a experiência internacional através da adoção da ISO/TS 15066 pode ser considerada como uma maneira de reduzir os riscos inerentes ao cobot em uma operação colaborativa. 
Quadro 14: Síntese dos resultados da análise comparativa

\begin{tabular}{|c|c|c|c|}
\hline Item & $\begin{array}{c}\text { NR-12 para robô } \\
\text { industrial } \\
\text { tradicional }\end{array}$ & Operação colaborativa & Referência \\
\hline 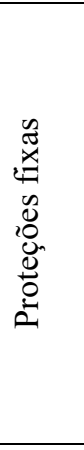 & & $\begin{array}{l}\text { De acordo com a literatura, os cobots são projetados para } \\
\text { trabalhos colaborativos e proporcionam uma cooperação com } \\
\text { os humanos. } \\
\text { Os cobots cumprem suas funções como unidades produtivas } \\
\text { independentes, com segurança, e sem necessidade de proteções } \\
\text { físicas. } \\
\begin{array}{l}\text { Uma característica da operação colaborativa é o } \\
\text { desenvolvimento do layout do posto de trabalho, que deve ser } \\
\text { flexível para alterações. }\end{array}\end{array}$ & $\begin{array}{l}\text { Ibarguren et al., } \\
2015 \\
\text { Müller, Vette e } \\
\text { Scholer, } 2016\end{array}$ \\
\hline $\begin{array}{l}\infty \\
0 \\
D \\
\Xi \\
0 \\
0 \\
0 \\
0 \\
0 \\
0 \\
0 \\
0\end{array}$ & & $\begin{array}{l}\text { Concebe-se o cobot com a função de parada monitorada de } \\
\text { segurança, que causa uma parada protetora antes que o } \\
\text { operador entre no espaço de trabalho colaborativo. } \\
\text { Não se habilita o cobot a entrar no espaço de trabalho } \\
\text { colaborativo, enquanto o operador estiver dentro dessa área. } \\
\text { A especificação técnica ISO/TS } 15066 \text { visa reduzir restrições } \\
\text { de contato na interação humano-robô. }\end{array}$ & $\begin{array}{l}\text { Hull e Minarcin, } \\
2016 \\
\text { Bdiwi, Pfeifer e } \\
\text { Sterzing, } 2017\end{array}$ \\
\hline 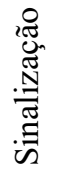 & & $\begin{array}{l}\text { Elaboração de apreciação de risco para identificação dos } \\
\text { aspectos de sinalização extra necessária. }\end{array}$ & $\begin{array}{l}\text { Gopinath e } \\
\text { Johansen, } 2016\end{array}$ \\
\hline 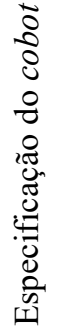 & & $\begin{array}{l}\text { Adoção de tecnologias já concebidas no projeto do mesmo, a } \\
\text { fim de limitar a potência dinâmica, força estática e velocidade, } \\
\text { em conformidade com o item } 5.4 \text { da ISO } 10218 \text { - parte } 1 \text {. } \\
\text { Não se recomenda o uso dos robôs tradicionais em operação } \\
\text { colaborativa, pois os mesmos não são colaborativos e seguros } \\
\text { para a operação colaborativa em sua concepção. }\end{array}$ & $\begin{array}{l}\text { Bdiwi, Pfeifer e } \\
\text { Sterzing, } 2017 \\
\text { Kootbally, } 2016\end{array}$ \\
\hline
\end{tabular}

Fonte: Autor

\subsection{SEGURANÇA NA OPERAÇÃO COLABORATIVA}

O segundo ponto a ser destacado é a importância da concepção do projeto de segurança de um sistema robótico tradicional ou colaborativo antes de sua implementação como prérequisito para a interpretação e aplicação da NR-12. Neste contexto, diversos autores propõem várias tecnologias de segurança para projetar um espaço de trabalho seguro, quando da implantação destes tipos de sistemas (PESHKIN; COLGATE, 1999; BOGUE, 2016). Tais tecnologias permitem o compartilhamento do mesmo espaço de trabalho com menos risco de lesões humanas, pois de maneira objetiva, essas tecnologias de segurança pretendem evitar 
colisões, devido a potenciais incidentes que podem ocorrer entre um robô e um operador durante uma operação colaborativa (VYSOCKY; NOVAK, 2016; CHARALAMBOUS; FLETCHER; WEBB, 2015). Dentre estas estratégias, propõe-se a implantação de diferentes tecnologias de segurança dentro do posto de trabalho, de acordo com o resultado da apreciação de riscos, tais como cortinas de luz, scanners, sistemas de visão para parada ou restrição de velocidade do robô (BERTOLINI et al., 2016) e de acordo com o projeto de segurança para sistemas robóticos, mostrado na Figura 9 e na Figura 10.

Destaca-se aqui o ambiente da manufatura avançada, onde espera-se que humanos e robôs ampliem a coexistência e a cooperação com segurança, (DJURIC; URBANIC; RICKLI, 2016; BLOSS, 2016), habilitando e compartilhando um mesmo espaço de trabalho (GROOVER, 2017; IBARGUREN et al., 2015), conforme mostrado na Figura 12. Para possibilitar esta coexistência, algumas tecnologias de segurança são incorporadas ao projeto dos robôs para aplicação na operação colaborativa.

Desta maneira, tecnologia de sensores sofisticados, controladores de segurança e redes de comunicação embarcadas no projeto do robô fornecem dados de segurança em tempo real, que permitem que os mesmos respondam automaticamente a possíveis incidentes ao contato físico com um operador (DJURIC; URBANIC; RICKLI, 2016). Esses dispositivos são capazes de reconhecer e detectar quaisquer objetos no ambiente circundante e, através da elaboração adequada deste tipo de informação, evitam possíveis colisões. No entanto, apesar dessas proteções inerentes adotadas em sua concepção, os cobots ainda representam riscos para o trabalho colaborativo.

Portanto, para se obter uma colaboração efetiva entre humanos e robôs (THIEMERMANN, 2004), é necessário planejar arranjos de layout e processos adequados (SCHOLER; VETTE; RAINER, 2015), especificação adequada dos cobots e definir deveres claros, considerando a capacidade e confiabilidade tanto do operador quanto do cobot (GROOVER, 2017; IBARGUREN et al., 2015), além da segurança que representa o problema central de um posto de trabalho colaborativo (GUIOCHET; MACHIN; WAESELYNCK, 2017; PEDROCCHI et al., 2013), e dos requisitos da NR-12.

O último ponto de destaque são os padrões atuais fornecidos pela ISO/TS 15066, que oferecem orientação sobre como a colaboração humano-robô pode manter a segurança nas operações colaborativas (GOPINATH; JOHANSEN, 2016; MARVEL et al., 2015) e que não são mencionados pela NR-12 pelo fato de a mesma não abranger os requisitos para o planejamento de segurança de um posto de trabalho colaborativo. 
Além da distribuição de habilidades entre o cobot e o operador descritas por Scholer, Vette e Rainer (2015), mostradas no Quadro 4, são destacados no Quadro 15 os aspectos mais importantes a serem levados em consideração de acordo com esses padrões, quando da implantação de uma operação colaborativa, segundo a literatura.

Quadro 15: Aspectos da colaboração conforme padrões ISO

\begin{tabular}{|c|c|c|}
\hline Aspectos da colaboração conforme padrões ISO & Autores & $\begin{array}{l}\text { Tipo de } \\
\text { operação } \\
\text { ISO/TS } 15066\end{array}$ \\
\hline $\begin{array}{l}\text { Os robôs projetados para operação colaborativa } \\
\text { devem fornecer uma indicação visual quando o } \\
\text { mesmo estiver em operação colaborativa. }\end{array}$ & $\begin{array}{l}\text { Bdiwi; Pfeifer; Sterzing, 2017; } \\
\text { Bertolini et al., 2016; Ibarguren et } \\
\text { al., 2015; Krüger; Lien; Verl, } 2009\end{array}$ & $\begin{array}{l}\text { Quatro tipos } \\
\text { colaboração }\end{array}$ \\
\hline $\begin{array}{l}\text { O cobot deve parar quando um humano estiver no } \\
\text { espaço de trabalho colaborativo, mas de maneira } \\
\text { alternativa o cobot pode desacelerar para evitar o } \\
\text { contato físico. }\end{array}$ & $\begin{array}{l}\text { Bdiwi; Pfeifer; Sterzing, 2017; } \\
\text { Guiochet, Machin, e Waeselynck, } \\
\text { 2017; Hull e Minarcin, 2016; } \\
\text { Navarro et al.; 2016; Cordero et al.; } \\
2014\end{array}$ & $\begin{array}{l}\text { Parada com } \\
\text { classificação } \\
\text { de segurança }\end{array}$ \\
\hline $\begin{array}{l}\text { O cobot deve limitar a potência dinâmica, força } \\
\text { estática e velocidade, em conformidade com o item } \\
5.4 \text { da ISO } 10218-1 \text {. }\end{array}$ & $\begin{array}{l}\text { Bdiwi; Pfeifer; Sterzing, 2017; } \\
\text { Tarouchi, Sotiris e Chryssolouris, } \\
\text { 2016; Shackleford et al., 2016; Hull e } \\
\text { Minarcin, } 2016\end{array}$ & $\begin{array}{l}\text { Limitação } \\
\text { potência \& } \\
\text { força }\end{array}$ \\
\hline $\begin{array}{l}\text { O cobot deve manter uma determinada velocidade } \\
\text { e distância de separação do operador. }\end{array}$ & $\begin{array}{l}\text { Bdiwi; Pfeifer; Sterzing, 2017; } \\
\text { Pedrocchi et al., } 2013\end{array}$ & $\begin{array}{l}\text { Monitoramento } \\
\text { velocidade \& } \\
\text { separação }\end{array}$ \\
\hline $\begin{array}{l}\text { As velocidades relativas do operador e do cobot } \\
\text { precisam ser consideradas, ao se calcular a } \\
\text { distância mínima de separação segura. }\end{array}$ & $\begin{array}{l}\text { Bdiwi; Pfeifer; Sterzing, 2017; } \\
\text { Pedrocchi et al., } 2013\end{array}$ & $\begin{array}{l}\text { Monitoramento } \\
\text { velocidade \& } \\
\text { separação }\end{array}$ \\
\hline $\begin{array}{l}\text { A detecção da falha em manter a velocidade ou a } \\
\text { distância de separação determinada resultará em } \\
\text { uma parada de proteção, conforme item } 5.5 .3 \text { da } \\
\text { ISO 10218-1. }\end{array}$ & $\begin{array}{l}\text { Shackleford et al., 2016; Tarouchi, } \\
\text { Sotiris e Chryssolouris, 2016; }\end{array}$ & $\begin{array}{l}\text { Monitoramento } \\
\text { velocidade \& } \\
\text { separação }\end{array}$ \\
\hline $\begin{array}{l}\text { As funções de monitoramento de velocidade e } \\
\text { separação devem estar de acordo com o item } 5.4 .2 \\
\text { da ISO 10218-1. }\end{array}$ & $\begin{array}{l}\text { Shackleford et al., 2016; Tarouchi, } \\
\text { Sotiris e Chryssolouris, 2016; }\end{array}$ & $\begin{array}{l}\text { Monitoramento } \\
\text { velocidade \& } \\
\text { separação }\end{array}$ \\
\hline $\begin{array}{l}\text { De maneira geral, deve-se especificar a carga útil a } \\
\text { ser aplicada ao cobot. }\end{array}$ & $\begin{array}{l}\text { Khalid et al., 2016; Bogue, 2016; } \\
\text { Djuric; Urbanic; Rickli, } 2016\end{array}$ & $\begin{array}{l}\text { Quatro tipos } \\
\text { colaboração }\end{array}$ \\
\hline
\end{tabular}

Fonte: Autor

Os aspectos da colaboração conforme a ISO/TS 15066 mostrados no Quadro 15 podem prever estratégias diferentes para alcançar a segurança na colaboração humano-robô. As mais importantes envolvem a limitação de potência e força e o monitoramento de velocidade e separação.

Ainda em relação aos aspectos da colaboração mostrados no Quadro 15, estudos sobre a tolerância à dor, que podem incluir uma lista de níveis máximos de força e pressão para cada parte do corpo humano para ajudar na evolução da determinação dos limites de potência e força a serem aplicados em uma operação colaborativa, não são objetos de análise deste estudo. 


\section{CONCLUSÕES E RECOMENDAÇÕES}

A normatização brasileira que regulamenta a utilização dos robôs no Brasil é tratada por meio da NR-12, sendo que a mesma aborda somente os aspectos de segurança relacionados aos sistemas robóticos tradicionais, não fazendo nenhuma distinção para abranger as características dos cobots. Desde que foi publicada a sua primeira edição em 1978, a NR-12 está estagnada, sem conseguir acompanhar a realidade dos avanços na manufatura. Neste sentido, o objetivo principal desta pesquisa foi compreender a limitação do uso do robô colaborativo nas operações colaborativas no setor industrial brasileiro, por meio da identificação de fatores limitadores da normatização.

Como o processo de automação pode levar a ganhos de produtividade, melhorar a qualidade, a eficiência e a redução de custos, a primeira conclusão é que o aumento do nível de automação nas empresas pode tornar o Brasil mais competitivo; contudo, é necessário que a normatização atual faça distinção entre os tipos de robôs industriais para uma utilização ampla das soluções colaborativas, a qual já é utilizada na Europa, tendo como base a especificação técnica ISO/TS 15066.

No ambiente da manufatura avançada, a colaboração entre humanos e robôs no chão de fábrica será uma das tendências para incrementar o desenvolvimento desse tipo de manufatura. A segunda conclusão mostra que as empresas e as entidades normativas brasileiras precisam considerar os novos riscos induzidos à segurança do operador durante uma operação colaborativa, e identificar como os cobots podem complementar a força de trabalho, quando usados nessas operações.

Um dos objetivos específicos trata da verificação de como a segurança na operação colaborativa é abordada em outros países. Um ponto importante detectado é que a velocidade de inovação tecnológica na indústria mundial ultrapassa sempre a velocidade de pesquisa e desenvolvimento de normas de segurança voltadas à robótica, especialmente aquelas voltadas aos protocolos de segurança aplicados ao cobot, nos quais a Europa se atualizou, criando em 2016 a especificação técnica ISO/TS 15066. A realidade no Brasil mostra que a normatização vigente não acompanha a velocidade com que as tecnologias são desenvolvidas e disponibilizadas para a indústria, ocasionando assim um atraso em regulamentar novas diretrizes de segurança, quando da utilização dos cobots.

O outro objetivo específico trata da realização de um comparativo das restrições relativas a segurança na operação colaborativa. Este trabalho ressalta que a especificação técnica ISO/TS 15066 visa reduzir restrições de contato na interação humano-robô durante a 
operação colaborativa e apresentam quatro modos de colaboração possíveis em uma operação colaborativa. Como esses modos de colaboração não são mencionados pela normatização, temos aqui o principal fator da normatização que impede o uso dos robôs colaborativos em sua plenitude nas operações industriais no Brasil.

Uma contribuição desta pesquisa mostra que, conforme informação contida na ISO/TS 15066, não existe robô seguro. Isso significa que em uma operação colaborativa o cobot ainda apresenta riscos de ferimentos graves, sendo ainda o humano o componente fundamental para este tipo de aplicação. Esta percepção não é mensurável na normatização, especificamente na NR-12.

Considera-se uma limitação desta pesquisa a aplicação somente junto ao setor industrial brasileiro, embora seja relevante para o contexto da manufatura avançada. Desta maneira, sugere-se que novas pesquisas sejam realizadas junto a outros setores da indústria e de serviços, de modo a observar melhor a interpretação da normatização brasileira quando da adoção do cobot.

A partir da revisão da literatura, notou-se que futuras pesquisas podem recomendar que as empresas adotem novos padrões de segurança no trabalho, incluindo a adoção da apreciação de novos riscos e dor induzidos ao humano. Propõe-se pesquisar também a mudança de paradigmas sobre as vantagens e desvantagens do uso do cobot em uma operação colaborativa. 


\section{REFERÊNCIAS}

ABI Research. Collaborative Robotics Market. 2015. Disponível em < https://www.abiresearch.com/webinars/collaborative-robotics-market-opportunities/>. Acesso em: 17 Mai. 2018.

ASSOCIAÇÃO BRASILEIRA DE MÁQUINAS E EQUIPAMENTOS (ABIMAQ). Normas regulamentadoras brasileiras - NR-12. Disponível em < http://abimaq.org.br/site.aspx/Destaques-home />. Acesso em: 25 ago. 2018.

ANTONELLI, D.; BRUNO, G. Human-robot collaboration using industrial robots. In: 2nd International Conference on Electrical, Automation and Mechanical Engineering (EAME 2017). Advances in Engineering Research. 2017. p. 99-102.

BERTOLINI, A. et al. On robots and insurance. International Journal of Social Robotics, v. 8, n. 3, p. 381-391, 2016.

BICCHI, A.; PESHKIN, M. A.; COLGATE, J. E. Safety for physical human-robot interaction. Springer handbook of robotics. Springer, Berlin Heidelberg, 2008. p. 1335-1348.

BDIWI, M.; PFEIFER, M.; STERZING, A. A new strategy for ensuring human safety during various levels of interaction with industrial robots. CIRP Annals-Manufacturing Technology, 2017.

BLOSS R. Industrial Robot: Collaborative robots are rapidly providing major improvements in productivity, safety, programing ease, portability and cost while addressing many new applications. Industrial Robot, an International Journal 43/5 (2016) 463-468.

BOGUE, R. Europe continues to lead the way in the collaborative robot business. Industrial Robot: An International Journal, v. 43, n. 1, p. 6-11, 2016.

BROWN, S.; BESSANT, J. The manufacturing strategy-capabilities links in mass customisation and agile manufacturing - an exploratory study. International Journal of Operations \& Production Management, v. 23, n. 7, p. 707-730, 2003.

CAUCHICK P. A. MIGUEL et al. Metodologia de pesquisa em Engenharia de Operações e gestão de Produção. $2^{\circ}$ edição. ABEPRO: Editora Campus, 2012. 260 p.

CERIANI, N. M. et al. Reactive task adaptation based on hierarchical constraints classification for safe industrial robots. IEEE/ASME Transactions on Mechatronics, v. 20, n. 6, p. 29352949, 2015.

CÉSPEDES L.; ROCHA D. F. Segurança e Medicina do Trabalho. São Paulo. $19^{\circ}$ edição. Editora Saraiva, 2017. 1297 p.

CHARALAMBOUS G.; FLETCHER S.; WEBB P. Identifying the key organisational human factors for introducing human-robot collaboration in industry: an exploratory study. Int J. Adv. Manuf. Technology (2015) 81:2143-2155.

CHEN, F. et al. Optimal subtask allocation for human and robot collaboration within hybrid assembly system. IEEE Transactions on Automation Science and Engineering, v. 11, n. 4, p. 1065-1075, 2014. 
CHERUBINI, A. et al. Collaborative manufacturing with physical human-robot interaction. Robotics and Computer-Integrated Manufacturing, v. 40, p. 1-13, 2016.

CHINNIAH, Yuvin; AUCOURT, Barthelemy; BOURBONNIÈRE, Real. Safety of industrial machinery in reduced risk conditions. Safety science, v. 93, p. 152-161, 2017.

CONSELHO NACIONAL DA INDÚSTRIA (CNI). Produtividade na indústria. Disponível $\mathrm{em}<\mathrm{http}$ //www.portaldaindustria.com.br/estatisticas/importancia-da-industria/ $>$. Acesso em: 12 jun 2018.

CORDERO, Cristina Alén et al. Experimental tests in human-robot collision evaluation and characterization of a new safety index for robot operation. Mechanism and machine theory, v. 80, p. 184-199, 2014.

CRESWELL, J. W. Investigação Qualitativa e Projeto de Pesquisa-: Escolhendo entre Cinco Abordagens. Penso Editora, 2014, 341 p.

DRATH, R.; HORCH, A. Industrie 4.0: Hit or hype? IEEE industrial electronics magazine, v. 8, n. 2 , p. $56-58,2014$.

DJURIC, A., URBANIC, R., AND RICKLI, J. A Framework for Collaborative Robot (CoBot) Integration in Advanced Manufacturing Systems. SAE International Journal of Materials and Manufacturing 9(2):457-464, 2016.

INTERNATIONAL STANDARDS FOR ORGANIZATION (EN ISO 121000: Safety of machinery - General principles for design - Risk assessment and risk reduction. ISO, Geneva (2010).

FLICK, U. Introdução a metodologia de pesquisa. Porto Alegre. Penso Editora, 2013. 256 p.

GASKILL, S. P.; WENT, S. R. G. Safety issues in modern applications of robots. Reliability Engineering \& System Safety, v. 53, n. 3, p. 301-307, 1996.

GERALDI, B., MAYLOR, H., WILLIAMS, T., 2011. Now, let's make it really complex (complicated) A systematic review of the complexities of projects. Int. J. Operat. Prod. Manag. 31 (9), $966-990$.

GIL, A. C. Como Elaborar Projetos de pesquisa. $4^{\circ}$ edição. São Paulo. Editora Atlas, 2002. $175 \mathrm{p}$.

GIL, A. C. Como Elaborar Projetos de pesquisa. $5^{\circ}$ edição. São Paulo. Editora Atlas, 2010. $184 \mathrm{p}$.

GOPINATH, V.; JOHANSEN, K. Risk Assessment Process for Collaborative Assembly - A Job Safety Analysis Approach. Procedia CIRP, v. 44, p. 199-203, 2016.

GROOVER, M.P. Automation, Production Systems, and Computer-Integrated Manufacturing. $4^{\circ}$ edição. Harlow Inglaterra. Editora Prentice Hall, Inc., Pearson Education. (809 p) 2017.

GROU, M. et al. Panorama do contexto do início da jornada na Quarta Revolução Industrial. In: SILVA, E.B. et al. Automação \& Sociedade: Quarta Revolução Industrial, um olhar para o Brasil. Rio de Janeiro. Brasport, 2018.P. 13-24. 
GUIOCHET, J.; MACHIN, M.; WAESELYNCK, H. Safety-critical advanced robots: A survey. Robotics and Autonomous Systems, v. 94, p. 43-52, 2017.

HEILALA, J.; VOHO, P. Modular reconfigurable flexible final assembly systems. Assembly Automation, v. 21, n. 1, p. 20-30, 2001.

HARPER C.; VIRK. G. Towards the Development of International Safety Standards for Human Robot Interaction. Springer Science \& Business Media. Int. J. Soc. Robot (2010) 2: 229-234.

HOLDER C. et al. Robotics and law: Key legal and regulatory implications of the robotics age (Part I of II). Computer law \& security review 32, 383-402. (2016). Reino Unido.

HULL, T.; MINARCIN, M. A. Considerations in Collaborative Robot System Designs and Safeguarding. SAE International Journal of Materials and Manufacturing, v. 9, n. 201601-0340, p. 545-551, 2016.

IBARGUREN A. et al. Multiple target tracking based on particle filtering for safety in industrial robotic cells. Elsevier (2015). Robotics and Autonomous Systems 72 (2015) 105 - 113.

INTERNATIONAL FEDERATION OF ROBOTICS (IFR). World Robotics 2016 Service Robots. Disponível em < http://www.ifr.org > . Acesso em: 27 Dez 2017.

INTERNATIONAL STANDARDS FOR ORGANIZATION (ISO 10218): Robots for Industrial Environments: Safety Requirements. Part 1: Robot, ISO 10218-1:2011, 2011.

INTERNATIONAL STANDARDS FOR ORGANIZATION (ISO 10218): Robots and Robotic Devices: Safety Requirements. Part 2: Industrial Robot Systems and Integration, ISO 10218-2:2011, 2011.

INTERNATIONAL STANDARDS FOR ORGANIZATION (ISO/TS 15066:2016): "Robots and robotic devices - collaborative robots, ISO/TS 15066: 2016, Feb. 2016.

KHALID, A. et al. A methodology to develop collaborative robotic cyber physical systems for production environments. Logistics Research, v. 9, n. 1, p. 23, 2016.

KOOTBALLY, Z. Industrial robot capability models for agile manufacturing. Industrial Robot: An International Journal, v. 43, n. 5, p. 481-494, 2016.

KRÜGER J.; LIEN T.K.; VERL A. Cooperation of human and machines in assembly lines. CIRP Annals - Manufacturing Technology 58 (2009) 628-646.

LIEN, T. K.; RASCH, F. O. Hybrid automatic-manual assembly systems. CIRP AnnalsManufacturing Technology, v. 50, n. 1, p. 21-24, 2001.

LOTTER, E. Montage in der industriellen Produktion. $2^{\circ}$ edição. Berlin. Editora Springer, 2012. $501 \mathrm{p}$.

MARVEL J. A.; FALCO J.; MARSTIO I. Characterizing Task-Based Human - Robot Collaboration Safety in Manufacturing. IEEE TRANSACTIONS ON SYSTEMS, MAN, AND CYBERNETICS: SYSTEMS, VOL. 45, NO. 2, (2015).

MARVEL, J. A. Performance metrics of speed and separation monitoring in shared workspaces. IEEE Transactions on Automation Science and Engineering, v. 10, n. 2, p. 405-414, 2013. 
MATTHIAS B.; REISINGER T. Example Application of ISO/TS 15066 to a Collaborative Assembly Scenario. ISBN 978-3-8007-4231-8. ISR 2016 (June 21 - 22, 2016, Munich, Germany).

MICHALOS, G. et al. Design considerations for safe human-robot collaborative workplaces. Procedia CIrP, v. 37, p. 248-253, 2015.

MICHALOS, G. et al. ROBO-PARTNER: Seamless Human-Robot cooperation for intelligent, flexible and safe operations in the assembly factories of the future. Procedia CIRP, v. 23, p. 71-76, 2014.

MINISTÉRIO DO TRABALHO E EMPREGO. Normas regulamentadoras. Disponível em $<$ http://trabalho.gov.br/seguranca-e-saude-no trabalho/normatizacao/normas regulamentadoras/>. Acesso em: 26 ago. 2018.

MÜLLER, Rainer; VETTE, Matthias; SCHOLER, Matthias. Robot Workmate: a trustworthy coworker for the continuous automotive assembly line and its implementation. Procedia CIRP, v. 44, p. 263-268, 2016.

MURASHOV, V.; HEARL, F.; HOWARD, J. Working safely with robot workers: Recommendations for the new workplace. Journal of occupational and environmental hygiene, v. 13, n. 3, p. D61-D71, 2016.

NAVARRO, Benjamin et al. An ISO10218-compliant adaptive damping controller for safe Physical Human-Robot Interaction. In: Robotics and Automation (ICRA), 2016 IEEE International Conference on. IEEE, 2016. p. 3043-3048.

NAVARRO B. et al. An ISO10218-compliant adaptive damping controller for safe Physical Human-Robot Interaction. IEEE International Conference on Robotics and Automation (2011). Estocolmo, Suécia.

ORE, F. et al. Human-Industrial Robot Collaboration: Application of simulation software for workstation optimisation. Procedia CIRP, v. 44, p. 181-186, 2016.

QIN, J.; LIU, Y.; GROSVENOR, R. A categorical framework of manufacturing for industry 4.0 and beyond. Procedia CIRP, v. 52, p. 173-178, 2016.

PEDROCCHI, N. et al. Safe human-robot cooperation in an industrial environment. International Journal of Advanced Robotic Systems, v. 10, n. 1, p. 27, 2013.

PEDERSEN, M. R. et al. Robot skills for manufacturing: From concept to industrial deployment. Robotics and Computer-Integrated Manufacturing, v. 37, p. 282-291, 2016.

PERVEZ, Aslam; RYU, Jeha. Safe physical human robot interaction-past, present and future. Journal of Mechanical Science and Technology, v. 22, n. 3, p. 469, 2008.

PESHKIN, M. A. et al. Cobot architecture. IEEE Transactions on Robotics and Automation, v. 17, n. 4, p. 377-390, 2001.

PESHKIN, M; COLGATE, J. E. Cobots. Industrial Robot: An International Journal, v. 26, n. 5, p. 335-341, 1999.

ROBOTIC INDUSTRIES ASSOCIATION (RIA). Colaborative robots. Disponível em < https://www.robotics.org/>. Acesso em: 22 Abr. 2018. 
ROWLEY, J.; SLACK, F. 'Conducting a Literature Review'. Management Research News 27(4), 2004, pp. 31-39.

Sampieri, R. H., Collado, C. F., Lucio, P. B. Metodologia de pesquisa. $5^{\circ}$ edição. Porto Alegre. Editora penso, 2013. 624 p.

SHACKLEFORD, W. et al. Performance Evaluation of Human Detection Systems for Robot Safety. Journal of Intelligent \& Robotic Systems, v. 83, n. 1, p. 85-103, 2016.

SCHOLER, M.; VETTE, M.; RAINER, M. A lightweight robot system designed for the optimisation of an automotive end-off line process station. Industrial Robot: An International Journal, v. 42, n. 4, p. 296-305, 2015.

STULGIENE A.; CIUTIENE R. Collaboration in the Project Team. Kaunas University of Technology, Lithuania. Economics and Management: 2014. 19 (2).

SU, S.F. et al. Industry 4.0: A Special Section in IEEE Access. IEEE Access, v. 5, p. 12257$12261,2017$.

TAKATA, S.; HIRANO, T. Human and robot allocation method for hybrid assembly systems. CIRP Annals-Manufacturing Technology, v. 60, n. 1, p. 9-12, 2011.

TAN, Jefferey Too Chuan et al. Safety strategy for human-robot collaboration: Design and development in cellular manufacturing. Advanced Robotics, v. 24, n. 5-6, p. 839-860, 2010.

THIEMERMANN, S. Direkte Mensch-Roboter-Kooperation in der Kleinteilemontage mit einem SCARA-Roboter. University of Stuttgart, Stuttgart (2004). 123 p.

TSAROUCHI, P.; MAKRIS, S.; CHRYSSOLOURIS, G. Human-robot interaction review and challenges on task planning and programming. International Journal of Computer Integrated Manufacturing, v. 29, n. 8, p. 916-931, 2016.

VASIC, M.; BILLARD, A. Safety issues in human-robot interactions. In: Robotics and Automation (ICRA), 2013 IEEE International Conference on. IEEE, 2013. p. 197-204.

VYSOCKY A.; NOVAK P. Human - robot collaboration in industry. MM Science Journal, 2016-June, pp. 903-906.

YIN, R. K. Estudo de caso - Planejamento e Métodos. Porto Alegre. $5^{\circ}$ edição. Editora Bookman, 2015. 290 p.

SLACK, N. et al. Administração da produção. São Paulo. $4^{\circ}$ edição. Editora Atlas, 2015. 697 p.

WANG, L. Collaborative robot monitoring and control for enhanced sustainability. International Journal of Advanced Manufacturing Technology, v. 81, 2015.

WANG, S. et al. Implementing smart factory of industrie 4.0: an outlook. International Journal of Distributed Sensor Networks, v. 12, n. 1, p. 3159805, 2016.

ZANCHETTIN, A. et al. Safety in human-robot collaborative manufacturing environments: Metrics and control. IEEE Transactions on Automation Science and Engineering, v. 13, n. 2, p. 882-893, 2016. 